(2) norden 



\section{De fyra modulernas modell}

Ett nytt nordiskt mobilitets- och residensprogram

Utredare: Riitta Heinämaa

TemaNord 2006:516 
De fyra modulernas modell

Ett nytt nordiskt mobilitets- och residensprogram

TemaNord 2006:516

(C) Nordiska ministerrådet, Köpenhamn 2006

ISBN 92-893-1287-4

Tryck: Ekspressen Tryk \& Kopicenter. Finns bara som Print-on-Demand.

Tryckt på miljövänligt papper som uppfyller kraven i den nordiska miljösvanemärkningen.

Publikationen kan beställas på www.norden.org/order. Fler publikationer på

www.norden.org/publikationer

Printed in Denmark

Nordiska ministerrådet

Store Strandstræde 18

DK-1255 Köpenhamn K

Telefon (+45) 33960200

Fax (+45) 33960202

\section{Nordiska rådet}

Store Strandstræde 18

DK-1255 Köpenhamn K

Telefon (+45) 33960400

Fax (+45) 33111870

www.norden.org

\section{Det nordiska samarbetet}

Det nordiska samarbetet hör till de äldsta och mest omfattande regionala samarbetsformerna i världen. Samarbetet omfattar Danmark, Finland, Island, Norge och Sverige samt Färöarna, Grönland och Åland. Det stärker samhörigheten mellan de nordiska länderna med respekt för nationella skillnader och likheter. Samarbetet ger bättre möjligheter att hävda nordiska intressen i omvärlden och främja goda grannförhållanden.

Samarbetet formaliserades år 1952 då Nordiska rådet grundades som ett forum för parlamentarikerna och regeringarna i de nordiska länderna. År 1962 ingick de nordiska länderna Helsingforsavtalet, som sedan dess har utgjort den grundläggande ramen för det nordiska samarbetet. År 1971 bildades Nordiska ministerrådet som ett formellt forum för samarbete mellan de nordiska regeringarna och den politiska ledningen i de självstyrande områdena Färöarna, Grönland och Åland. 


\section{Innehåll}

Förord.

DEL I: Introduktion

9

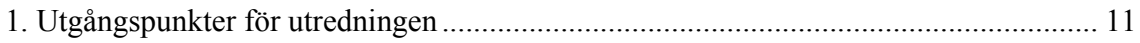

1.1 Strukturreformen för det nordiska kultursamarbetet............................................ 11

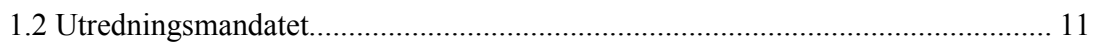

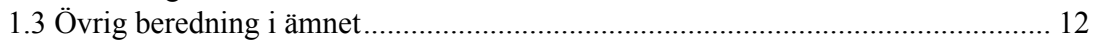

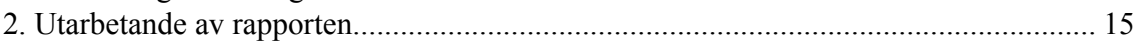

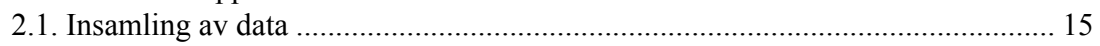

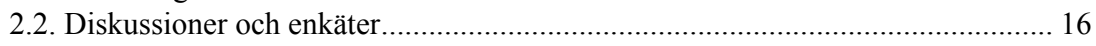

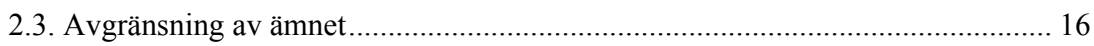

DEL II: Kartläggning av mobilitets- och residensprogram ........................................ 19

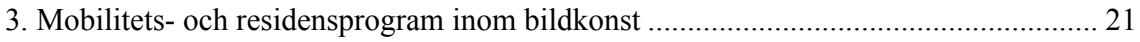

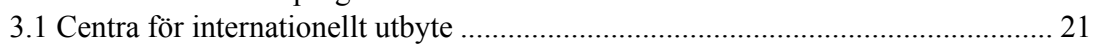

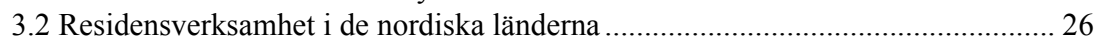

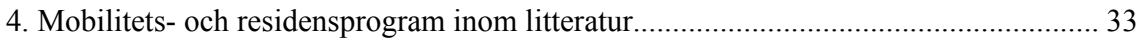

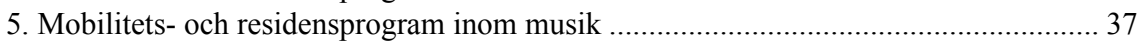

6. Mobilitets- och residensprogram inom scenkonst.................................................... 39

7. Mobilitets- och residensprogram i regi av Nordiska ministerrådet .............................. 41

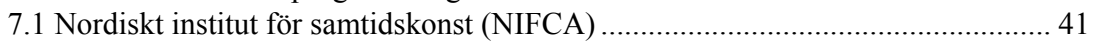

7.2 Resestipendieprogrammet Sleipnir.................................................................. 43

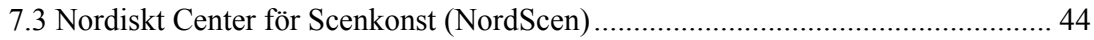

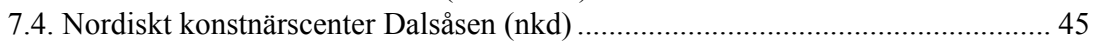

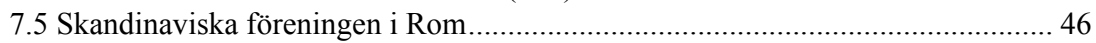

7.6 Övrig verksamhet i samband med mobilitet ...................................................... 47

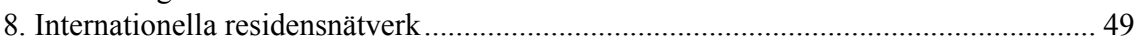

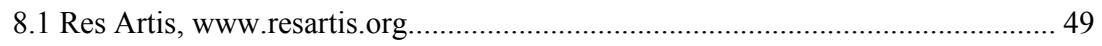

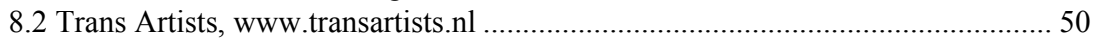

DEL III: Nuvarande läge och behov ............................................................................ 53

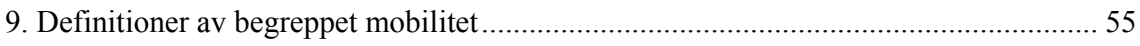

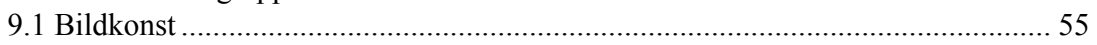

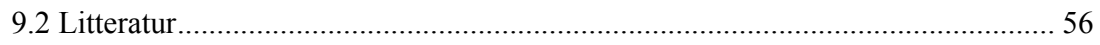

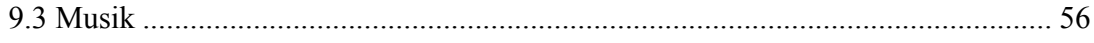

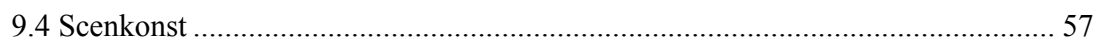

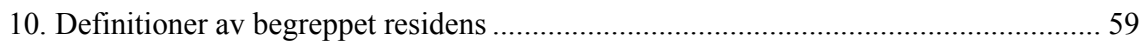

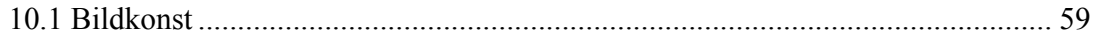

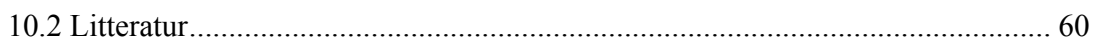

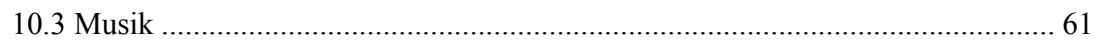

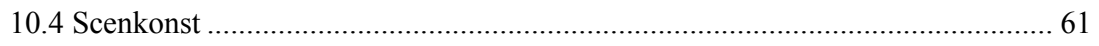

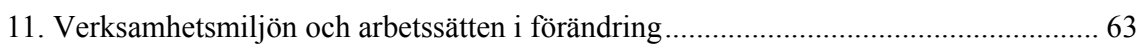

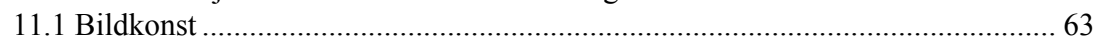

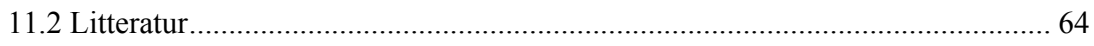

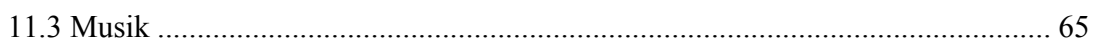

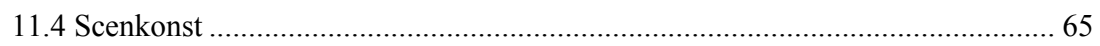

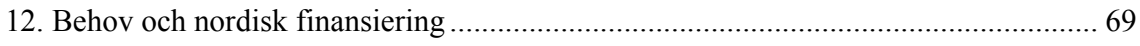

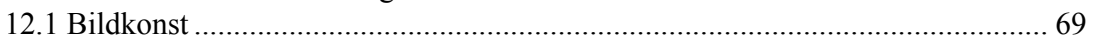

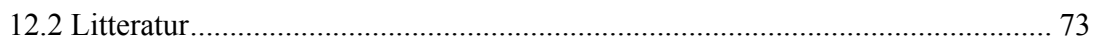

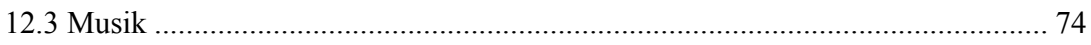

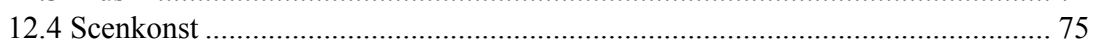




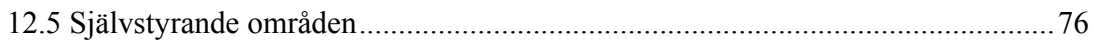

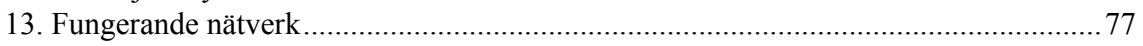

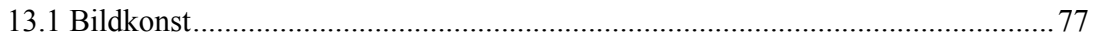

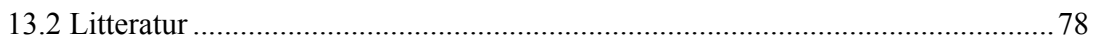

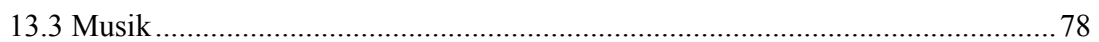

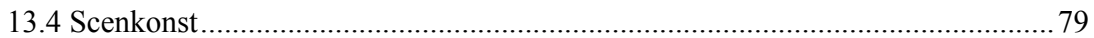

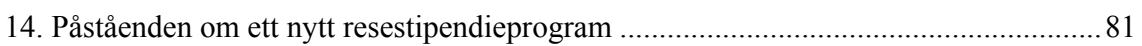

Del IV: " De fyra modulernas modell"

- Förslag till ett nytt mobilitets- och residensprogram ...............................................83

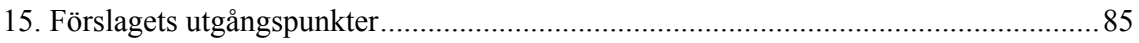

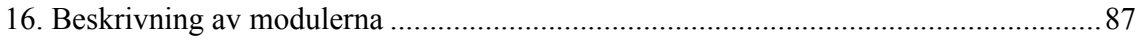

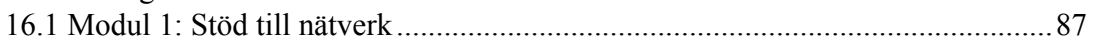

16.2 Modul 2: Samarbetscirkel/krets för konstnärsresidenser....................................... 88

16.3 Modul 3: Produktionsinriktad residensverksamhet (Artist-in-Production) ..........89

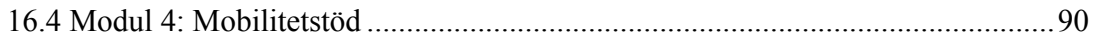

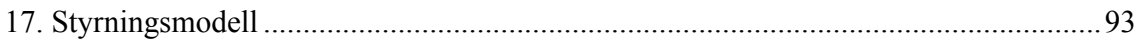

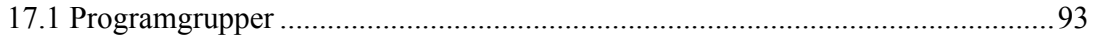

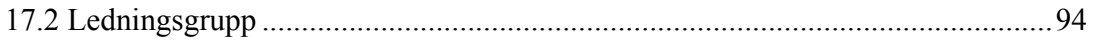

17.3 Beredning av beslut för produktionsinriktad residensverksamhet...........................94

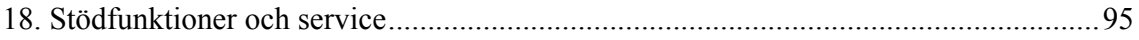

19. Utvecklingsmöjligheter för de nuvarande nordiska mobilitetsprogrammen................97

19.1 Skandinaviska föreningen i Rom ................................................................... 97

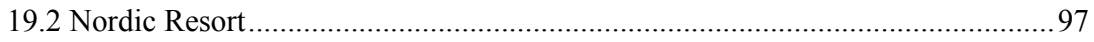

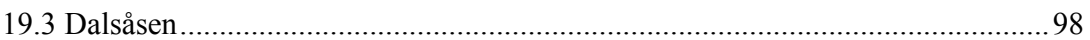

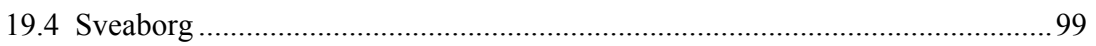

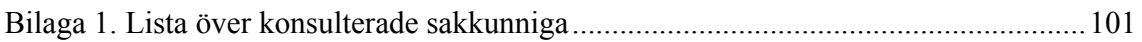

Bilaga 2. Lista över konsulterade nordiska organisationer.............................................. 102

Bilaga 3. Enkät till nordiska konstnärsorganisationer - de som svarat

Bilaga 4. Enkät till bilaterala fonder och vänskapsföreningar - de som svarat och sammandrag av svaren........................................................ 107

Bilaga 5. Lokaler som disponeras av Nordiska institutet för samtidskonst - NIFCA ..... 117

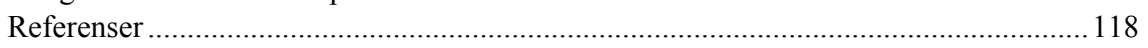

Kort om utredaren ........................................................................................... 119 


\section{Förord}

"Det finns en struktur, använd dig av den!" Det var det enkla råd fick jag av många när jag inledde arbetet med utredingen.

Det har varit mycket givande att arbeta med utredningen och jag har kunnat skönja att man på kulturfältet förhåller sig mycket positivt till ett nya mobilitets- och residensprogrammet. Även om det råder delade meningar om strukturreformen inom det Nordiska kultursamarbetet är det uppenbart att idén om att dirigera medel till mobilitet har ett brett stöd.

Utredningen har också var en utmaning. Ju längre jag kom i arbetet desto klarare blev det att alla konstarter har ett stort behov av mobilitet, men att de olika konstarternas behov är av helt olika karaktär. Jag hoppas att de förslag jag presenterar skall möta den efterrågan och de behov som finns.

Jag anser att det nya mobilitets- och residensproragmmet skall erbjuda möjligheter till samarbete för redan verksamma organisationer och residenser, men att det också skall peka på nya verksamhetsformer. Programmet skall på ett modernt, smidigt och effektivt sätt svara på de behov som de olika konstarterna har.

I min utredning har jag betraktat konstområdet ur ett brett perspektiv. Det är inte endast konstnärerna som behöver mobilitetsordningar utan också de andra nivåerna på konst- och kulturfältet. Målet är att skapa förutsättningar att knyta kontakter och att utveckla gemensamma intressen och att stärka den nationella utvecklingen.

I utredningen har ja använt ett omfattande material i form av skriftligt material, intervjuer och diskussioner. I utredningen har jag presenterat det så som jag har förstått det och därför är det jag som ansvarar för ev. feltolkningar ochj andra brister.

Arbetet har gett mig nöjet att samarbeta med sakkunniga över hela Norden. Jag vill tacka alla sakkunniga och alla repesentanter för de nordiska konstinstitutionerna och - kommittéerna som har delat med sig av sina erfarenheter, sitt kunnande och sin tid. Jag vill också tacka alla de nordiska konstnärsorganisationerna, de bilaterala fonderna och föreningarna som svarade på den elektroniska enkät som ingår i utredningen.

Ett speciellt tack går till producent Mervi Sainio, som har arbetat som min assistent i utredningsarbetet. Sainio har målmedvetet arbetat med kartläggningen av de nuvarande mobilitets- och residensordningarna och fungerat som en oersättlig hjälp i hela processen.

Helsingfors, februari 2006

Riitta Heinämaa 
DEL I: Introduktion 


\section{Utgångspunkter för utredningen}

\subsection{Strukturreformen för det nordiska kultursamarbetet}

Det nordiska kultursamarbetet håller på att gå in i en ny tidsålder. Den rapport som framlagts av en arbetsgrupp som förberett strukturreformen ger en bra bild av målsättningarna för hela strukturreformen och visar på vilka nya verksamhetsformer man strävar till. Det nordiska kultursamarbetet indelas i framtiden inte längre i sektorer enligt konstart eller förmedlingssätt. Denna linjedragning har också varit en av utgångspunkterna för utredningsarbetet.

"I stället inrättas tematiserade, tidsbundna program, som kan täcka hela eller klart definierade delar av kulturfältet. Detta är en logisk följd av att en allt större del av kulturlivet arbetar i tvärkonstnärliga konstellationer och i ständigt föränderliga nätverk. Genom att inte definiera sektorer utan målsättningar och problemställningar kan det nordiska kultursamarbetet breddas och fördjupas och också nå ut till nya nätverk."

I arbetsgruppens rapport drar man upp övergripande riktlinjer och målsättningar också då det gäller mobilitet. Enligt arbetsgruppens linjedragningar kommer mobilitetsprogrammen att utökas och utvecklas och mobiliteten kommer att gälla både professionella personer och kulturprodukter/verk.

"Inom mobilitetsprogrammet för personer är det möjligt för konstnärer, utövare av alla slag, översättare, förmedlare att söka stipendier som gör det möjligt för dem att besöka institutioner, organisationer, ateljéer, workshops etc. i grannländerna och bilda nätverk för fortsatt utbyte. Mobilitetsprogrammet för personer handlar om bilateralt utbyte och förutsätter inte att det är tre länder involverade. Jfr. Nordplus programmen, som högskolorna och universiteten i Norden administrerar mer eller mindre automatiskt."

\subsection{Utredningsmandatet}

Utredningens mandat baserar sig på det beslut som kulturministrarna fattade 15.6.2005 och som preciserades vid kulturministrarnas möte 26.10.2005.

MR-K beslutter, at 
- etablere et mobilitets- og residensprogram, som er åbent for alle kunstarter fra 1.1.2006.

- Ministerråd (kultur) afsætter MDKK 10,0 til formålet i budget 2006.

- Programmet skal tage udgangspunkt i Mobilitetsprogrammet Sleipnir samt de mobilitets- og residensaktiviteter, som hidtil har været udviklet og administreret af NIFCA, Kunstnercentret Dalsåsen og NordScen. Midlerne fra disse aktiviteter lægges ind i programmet fra 2006, men ordningerne administreres som i 2005, så langt det er muligt.

- Kunstnerkollegiet i Rom skal inviteres til at udgøre en del af residensprogrammet i en treårig forsøgsperiode 2007 - 2009. Derefter evalueres aktiviteten. Midlerne til Kollegiet er indlemmet i programmet fra 2006. Dalsåsen inddrages ligeledes i dette arbejde.

- Mobilitets- og residensprogrammet skal være et flerårigt program. Et konkret forslag for rammerne til etablering af et bredere anlagt flerårigt program, og hvordan det skal administreres fremlægges for MRK senest på møde 2/2006.

Utgående från detta beslut har syftet med utredningen formulerats enligt följande:

\footnotetext{
"Utredaren skall göra en kartläggning av de mobilitets - och residensprogram som administreras av de nordiska organen och av de ordningar som administreras i länderna, antingen av nationella myndigheter eller av centrala konstorganisationer. På basen av denna överblick skall utredaren komma med konkreta förslag till hur ett nordiskt mobilitets- och residensprogram för personer kunde inrättas så att det på bästa sätt skulle utgöra ett dynamiskt komplement till nationella och internationella ordningar och inte överlappa redan existerande ordningar. Utredaren skall presentera ett konkret förslag för ämbetsmannakommittéen för kultur den 15.2.2006 och på Nordisk kulturforum den 27.2.2006.”
}

\section{3 Övrig beredning i ämnet}

Det utredningsarbete som gäller rytmisk musik kommer att kompletteras av Dansk Rock Samråds (ROSA) förberedelsearbete. Under våren 2006 kommer ROSA med stöd av Nomus att anordna tre seminarier om rytmisk musik i Norden. Ett av dessa seminarier kommer att behandla musik och mobilitet i Norden. På seminaret kommer ROSA att

\footnotetext{
"afdække vilkårene for den rytmiske musiks bevægelse rundt i de nordiske lande og gerne komme ind på den nordiske kulturpolitiske struktur, hvilke muligheder og begrænsninger, der er indenfor det nordiske system, hvad der sker med musikområdet efter NOMUS og evt. hvilke muligheder, der findes for at etablere internordiske mobilitetsprogrammer for musik."
}

Det är stundom svårt att dra en gräns mellan mobilitet för personer och mobilitet för verk. En av Nordiska ministerrådet tillsatt arbetsgrupp "Ar- 
betsgruppen för stöd till konstsamarbete i Norden" kommer i sin beredning också att behandla mobiliteten för olika verk. Arbetsgruppens uppgift är viktig och omfattande:

"Arbejdsgruppen skal forberede et grundlag for drøftelserne af rammerne for et eller flere kunstprogrammer, som skal erstatte og kan videreføre væsentlige funktioner inden for de enkelte fagområder i forhold til det fællesnordiske kultursamarbejde." 


\section{Utarbetande av rapporten}

I utredningen behandlar jag mobilitets- och residensprogrammen ur kulturpolitiskt perspektiv (presentation av nuvarande mobilitets- och residensprogram), ur konstsamfundets perspektiv (utvecklingsbehov och nuläge) samt ur administrativ synvinkel (planering av det nya programmet).

\subsection{Insamling av data}

Jag presenterar nuvarande mobilitets- och residensprogram i form av en förteckning. Förteckningen är inte heltäckande men torde ge en överblick av existerande utbud. Då jag uppgjorde förteckningen kunde jag inte förutse en hur stor förändring inom nordiskt kultursamarbete det kommer att bli fråga om då man övergår från ett sektortänkande till tematiska program. Inom en sektor administreras innehållen i linjeorganisationen och det är ofta tillräckligt att man upprätthåller kontakten till linjeorganisationens centrala aktörer. De tematiska programmen är däremot decentraliserade och genomkorsar ett flertal kulturpolitiska program. Bland annat International Federation of Arts Councils and Cultural Agencies (IFACCA) har betonat att man då det gäller mobilitet bör beakta bland annat följande kulturpolitiska program:

- Kultursamarbete

- Kulturutbyte

- Konstnärsutbyte

- Resestipendium

- Internationellt forskningsstipendium

- "Go and see" -stipendier

- Program för internationella samproduktioner

- Internationellt program för studiovistelse, residens

- Internationell turné

I praktiken innebär det här att det inte finns ett eller endast några ställen från vilka man centraliserat skulle kunna få upplysningar om de nordiska mobilitets- och residensprogrammen. Alla uppgifter är ytterst fragmentariska. Strukturerna är olika i de olika nordiska länderna och även om aktörerna har samma status som myndighet, så kan de ha olika uppdrag, ansvar och uppbyggnad. En utmaning vid insamlandet av data är också att residensverksamheten ofta är lokalt förankrad och åtnjuter kommunalt 
stöd. Det är svårt att få adekvata uppgifter om den lokala residensverksamheten.

\subsection{Diskussioner och enkäter}

För utredningsarbetet har jag fört ett flertal samtal med experter från konstfältet och med representanter för nordiska institutioner och kommittéer (namnlistor som bilaga 1. och 2.). Nordiska ministerrådet har inte ställt några krav på vem jag borde kontakta. Alla kontakter har baserat sig på mitt eget initiativ och omdöme.

Jag har för utredningen också utarbetat två enkäter. Den ena elektroniska enkäten sändes till 117 nordiska konstnärsorganisationer. Totalt besvarade $26 \%$ av organisationerna enkäten (lista på dem som svarat och frågeformuläret som bilaga 3.). Enligt min åsikt kan man utgående från svaren göra sig en relativt klar bild av hur mycket de olika konstområdenas uppfattning om mobilitet och residensverksamhet skiljer sig från varandra och framförallt av hur mycket behoven inom de olika konstområdena skiljer sig från varandra. Ur svaren framgår också enligt min mening hur omfattande behov man inom alla konstområden har beträffande mobilitet och residensverksamhet. Jag tror att man har svårt att svara på dessa behov om man inte samtidigt försöker förstå på vilket sätt konstfältet håller på att förändras. De svar som gäller förändring av verksamhetsmiljö och arbetssätt samt fungerande nätverk är fragmentariska, men desto mer belysande. Jag har grupperat konstnärsorganisationernas svar enligt konstområde och granskat dem som en del av utredningen (kapitel 9-14).

Den andra enkäten sändes till 30 bilaterala fonder och vänskapsföreningar. Allt som allt besvarade $60 \%$ av fonderna och vänskapsföreningarna enkäten (sammanfattning av dem som svarade och enkäten som bilaga 4.). Dessa fonder delar årligen ut betydande summor i stipendier. En stor del av dessa stipendier beviljas uttryckligen som vistelsestipendier, resestipendier och/eller veckostipendier. Ur svaren framgår det i hur stor utsträckning de bilateral fondernas verksamhetsförutsättningar skiljer sig från varandra. Det här å sin sida påverkar de bilaterala fondernas och vänskapsföreningarnas förutsättningar att koordinera sitt samarbete. Ur svaren kan man också utläsa att man i ansökningskriterierna i allmänhet inte skiljer på professionell och amatörverksamhet.

\subsection{Avgränsning av ämnet}

Utredningen befattar sig inte med hindren för mobilitet och hur man skulle kunna reducera dem. Ett flertal av hindren för mobilitet som t.ex. beskattning, mervärdeskatt, upphovsrätt och socialskydd beror på skillnader i de nationella lagstiftningarna. Men hindren för mobilitet kan också ha 
andra än juridiska orsaker. Språkmurar eller avsaknad av residensplatser på något geografiskt område kan utgöra ett hinder. SICA:s konferensrapport "Artists on the Move" ger upplysning om litteratur som behandlar hinder för mobilitet, om organisationer som arbetar med mobilitet samt om webbportaler som är specialiserade på området. Rekommenderas kan också en allmän översikt i ämnet, en undersökning gjord vid Université de Paris X "Study on the Mobility and Free Movement of People and Products in the Cultural Sector". Bland nordiska publikationer kan man bekanta sig med exempelvis det i Sverige utgivna verket "Konstnärerna och trygghetssystemen".

Utredningen befattar sig inte med utomlands belägna residens som ägs eller administreras av nordiska instanser. Uppgifter om dem kan bäst fås via de nordiska konstnärsorganisationernas och ministeriernas internationella avdelningar. Utredningen presenterar inte heller internationella residensprogram. I utredningen presenteras kort tre centrala informationskällor, med vars hjälp man har möjlighet att bekanta sig med internationella residensprogram

Uppgifter om internationella residensaktiviteter fås också på adressen www.artiste-residences.org, Med residensverksamhet i USA kan man bekanta sig på adressen www.artistcommunities.org och afrikanska residensaktiviteter finns på www.yatfund.org/e index5.html. Europeiska mobilitetsprogram som finansieras av European Cultural Foundationin (ECF) hittar man på adressen www.eurocult.org. Man kan på sidorna http://www.art4eu.net/residart bekanta sig med residensverksamhet inom teater- och danscentra. En bra informationskälla är också IFACCA:s rapport "Artists' International Mobility Programs", som innehåller en sammanställning av enkätsvar beträffande residensverksamhet som upprätthålls av konstkommissioner och kulturagenturer samt en heltäckande länk- och referenslista. Bland annat Sveriges Författarförbund presenterar utförligt internationell residensverksamhet som riktar sig till författare på adressen www.forfattarforbundet.se. 


\section{DEL II: Kartläggning av mobilitets- och residensprogram}




\section{Mobilitets- och residensprogram inom bildkonst}

\subsection{Centra för internationellt utbyte}

Alla de nordiska länderna har under de senaste tio åren skapat sina egna internationella centra för bildkonst. FRAME (Finnish Fund for Art Exchange) inledde sin verksamhet år 1992 och IASPIS (International Artists' Studio Program in Sweden) å sin sida 1996. I anslutning till OCA (Office for Contemporary Art Norway) grundades International Studio Program Oslo år 2003. CIA (Center for Icelandic Art) inledde sin verksamhet 2005 ja DIVA (Danish International Visual Art Exchange Program) å sin sida i år.

\section{Finnish Fund for Art Exchange (Frame), www.frame-fund.fi}

Frame fungerar som center för internationellt utbyte inom visuell konst. Centret har ett populärt stipendieprogram som gör det möjligt att stöda finska konstnärer att producera, ställa ut och presentera sina verk utomlands. Frame har delvis också egna produktioner och samarbetsprojekt antingen med finska eller utländska partners. Frame har ett eget gästprogram för kritiker, kuratorer, konsthistoriker och forskare. Frame satsar också på information om nutidskonst, bland annat genom att på sina nätsidor presentera månadens konstnär. Frame har också en egen diskussionskanal, en publikation vid namn Framework: The Finnish Art Review.

Frame har ett forskningsinriktat residensprogram för internationella kuratorer. Däremot har Frame inget eget residensprogram utan samarbetar med Helsinki International Artists Programme (HIAP) och Bildkonstakademin. Arbetsfördelningen mellan Frame och HIAP har länge varit den att Frame svarar för "exporten" af finska konstnärer medan HIAP å sin sida står för "importen" av internationella konstnärer. På senaste tid har HIAP dock haft projekt inom vilka man svarat för såväl "import" som "export". Det har då varit fråga om ömsesidiga enstaka konstnärsutbyten, bland annat med Korea, Tyskland och Spanien. Frame har dock varit med och deltagit i finansieringen av dessa projekt.

Frame ger finska konstnärer möjlighet att delta i följande internationella residensprogram: The Rijksakademie van Beeldende Kunsten i Amsterdam (www.rijksakademie.nl), Centre for Contemporary Art - Ujazdowski Castle i Warszawa (http://csw.art.pl/a-i-r), Centre d'Art i Natura de Ferrera i Katalonien (http://farrera.ddl.net/can), Foundation for Art and Creative Technology - FACT i Liverpool (http://www.fact.co.uk), Gallery 
Miroslav Kraljevic/ GMK, i Zagreb (www.miroslav-kraljevic.hr), [A.I.T.] Arts Initiative Tokyo Residency Programme i Tokyo (www.a-i-t.net), EXO experimental org i Sao Paulo (www.exo.org.br), Galerie Vermelho i Sao Paulo (http://www.galeriavermelho.com.br/v2/index.asp), Location One i New York (www.location1.org) och SPACEX i Exeter (www.spacex.co.uk).

Till Frames direktion hör representanter för undervisningsministeriet samt representanter för Helsingfors stad och konstnärsorganisationer. Direktionen utnämner en expertkommittée som består av fem personer (International Advisory Board). Vid sidan av direktören arbetar i Frame fem heltidsanställda personer. Frame kommer i framtiden att sträva till att stöda tillblivelsen av sådana långvariga produktions- och forskningsinriktade residensaktiviter som också ger möjlighet att ställa ut verk.

International Artists' Studio Program in Sweden (IASPIS), www.iaspis.com

IASPIS är ett svenskt utbytesprogram med uppgift att skapa dialog mellan bild- och formkonstnärer i Sverige och internationell samtidskonst. IASPIS verksamhet omfattar ett internationellt residensprogram i Sverige. IASPIS förfogar över 11 gästateljéer i Konstakademin i Stockholm och dessutom över gästateljéer i Malmö, Göteborg och Umeå för internationella gästande konstnärer. IASPIS hyr i Stockholm ett konstnärshotell vid namn Art Hotel.

IASPIS regionala verksamhet har en stark lokalförankring i en intressant miljö. I Malmö samarbetar IASPIS med Malmö konstmuseum, Högskolan för Konst och Kommunikation (K3), Konsthögskolan i Malmö, Malmö Konsthall, Rooseum, Form design center, Signal, Emma Reichert, Carl Lindh och Lunds Konsthall. I Göteborg består samarbetspartnerna av Göterborgs kulturförvaltning, Göterborgs Konstmuseum, Konsthögskolan i Valand, Högskolan för fotografi och film (HFF), Konstepidemin och Göteborgs Konsthall. I Umeå samarbetar IASPIS med instanser som Umeå kommun, Galleri Ahnlund, Galleri Stefan Andersson, Konsthögskolan i Umeå, Bildmuseet, Verkligheten och Museum Anna Norlander.

För svenska konstnärer har IASPIS ansökningstid till ateljéerna två gånger per år. IASPIS reserverar årligen en kvot för två nyexaminerade konstnärer. Det finns inget ansökningsförfarande för internationella konstnärer utan de inbjuds att delta i programmet. Nordiska och baltiska konstnärer har kunnat ansöka om ateljéer via NIFCA. Förutom för ateljén svarar IASPIS för konstnärens logi och resekostnader samt beviljar konstnären ett stipendium.

IASPIS erbjuder också svenska konstnärer ett internationellt residensprogram, i vilket det ingår fem ateljéer. Till alla ateljéer anknyts ett stipendium och vistelsen i dem är för det mesta långvarig (1 år). Nu är IASPIS' samarbetspartners Künstlerhaus Bethanien i Berlin (www.bethanien. de), Platform Garanti i Istanbul (www.platform.garanti.com. tr), ACME i 
London (www.artistsineastlondon.org.uk), ISCP i New York (www.iscpnyc.org) och AIT Arts Initiative Tokyo i Tokyo (www.a-i-t.net).

IASPIS' verksamhet är produktionsinriktad. I sin verksamhet betonar IASPIS att residensprogrammet inte får vara alltför "slutet" utan att man till det måste knyta en publik verksamhet med föreläsningar, utställningar och publikationer. IASPIS bjuder in konstnärer, kuratorer, kritiker och konstteoretiker för att föreläsa eller delta i seminarier. IASPIS har också ett eget kuratorsprogram inom vilket man inbjuder gäster. Besöken räcker i allmänhet 2-5 dagar och man betalar gästernas resor och logi. IASPIS har också specialprojekt, bland vilka till exempel Craft in Dialogue var en extra satsning på konsthantverk och design. Genom projektet ville IASPIS förstärka svenska konsthantverkares internationella synlighet och kontakter. Ibland initierar och organiserar IASPIS utställningar utomlands. IASPIS har till exempel sedan några år organiserat sidoutställningar i samband med Venedig biennalen.

Administrativt är IASPIS en del av Konstnärsnämnden. IASPIS har en fyra personers delegation. Vid sidan av en konstnärlig ledare som utnämns på viss tid arbetar inom IASPIS fyra heltidsanställda personer, som alla har mycket konstnärsnära arbetssätt. IASPIS har spelat en betydande roll i internationaliseringen av svensk konst. Man har inom svensk kulturpolitik gjort stora ekonomiska satsningar på IASPIS' verksamhet och detta har också gett resultat. I Internationella kulturutredningen 2003 utvärderas IASPIS' verksamhet synnerligen positivt och i utvärderingen konstateras att verksamheten är "grundad på konstnärernas egna behov". Utvärderingen rekommenderar att IASPIS-modellen förutom inom bildkonst skulle prövas också inom andra konstområden.

\section{Office of Contemporary Art (OCA), www.oca.no}

International Studio Programme Oslo (ISP-Oslo) som administreras av Office of Contemporary Art består av två ateljéprogram. OCA inbjuder internationella konstnärer till Norge för ett program som sträcker sig från 2 veckor till 6 månader. Till vistelsen anknyts ofta en utställning eller någon annan programinriktad verksamhet, men gästen kan också koncentrera sig enbart på sitt arbete som residenskonstnär. Inom programmet förfogar OCA över fyra ateljéer i Kunstnerernes Hus, som man också samarbetar med i utställningssammanhang. Från 2005 har man härtill haft tillgång till Edward Munchs forna ateljé i Ekely som tidigare administrerades av utrikesministeriet. Programmet täcker konstnärens resekostnader och logi, transporter och försäkring samt en del av produktionskostnaderna.

OCA svarar för programverksamheten i anslutning till residensprogrammet och organiserar bland annat föreläsningsserier med olika samarbetspartners. OCA har också ett International Visitor Programme inom vars ram man erbjuder korta, komprimerade besök åt kuratorer. Man ber i allmänhet gästerna om en rapport om vilka kontakter de etablerat under 
sitt besök och om med vilka konstnärer/utställningar de eventuellt kommer att samarbeta med. OCA:s verksamhet omfattar härtill andra internationella uppgifter som att ansvara för presentationen av norsk konst på internationella biennaler och konstmässor. OCA stöder också de norska konstnärernas och kuratorernas internationella deltagande. OCA har ett internationellt residensprogram för närvarande på följande platser: ISCP New York City (www.iscp-nyc.org), Platform Garanti Istanbul Residency Program (www.platform.garanti.com.tr), Künstlerhaus Bethanien, Berlin (www.bethanien.de), Residency Beijing Platform China Residency (www.platformchina.org) och Residency Berlin Mitte (www.kw-berlin.de).

OCA har en direktion som består av fem medlemmar. Till direktionen hör en representant för konstuniversiteten, en gallerist, en konstnär, en muséechef och en representat för utrikesministeriet. Vid OCA finns härtill en internationell expertisgrupp (International Board) som består av tre personer. I OCA arbetar vid sidan av ledaren en personal av varierande storlek. OCA har i sin verksamhet hittills varit forskningsinriktad men som följd av en utvärdering som gjordes för ett år sedan kommer OCA att småningom övergå till en mera produktionsinriktad verksamhet. Man kommer också att bredda sitt samarbete med aktörer i olika länder och leta efter samarbetspartners i nyckelställning.

Danish International Visual Art Exchange Program (DIVA), www.kunststyrelsen.dk/DIVA

Danska konstnärer har redan länge haft möjlighet till residens utomlands. Billedkunstcentret som numera lyder under Kunststyrelsen har ett internationellt residensprogram på följande platser: Berlin Mitte - Residency (www.kw-berlin.de), New York - International Studio and Curatorial Program, ISCP (www.iscp-nyc.org), Los Angeles - Otis College of Art and Design, i samarbete med Otis College of Art and Design, OCAD (www.otis.edu), Paris - Legatbolig i Cité International des Arts (www. kunststyrelsen.dk/5620029). På Kuba finns det möjlighet till studievistelse för danska kuratorer. I år har Billedkunstcentret dock inlett ett nytt internationellt residensprogram vars syfte är att locka internationella konstnärer till Danmark.

Det nya programmets målsättning är att höja den internationella standarden på dansk konstliv. Billedkunstcentret utförde ett grundligt planeringsarbete och programmet följer två modeller. Man kan å ena sidan skönja drag lånade från IASPIS, å andra sidan påminner programmet om det i Berlin belägna DAAD (www.daad-berlin.de). DIVA erbjuder konstnären residens för en längre tid (3-6 månader) samt betalar konstnärens resor och logi. Dessutom beviljas konstnären ett månatligt vistelsestipendium. I gengäld förutsätts konstnären deltaga i olika aktiviteter, i exempelvis en workshop, utställning eller hålla en föreläsning. Programmet förfo- 
gar över Kollegiefonden Bikubens gästbostäder i Köpenhamn, Odense och Örestad.

Programmets gästande konstnärer väljs i samarbete med det danska konstfältet. De danska konstorganisationerna, enskilda konstnärer och gallerier har möjlighet att föreslå konstnärer till programmet. Samtidigt presenterar förslagsgivaren en plan för på vilket sätt man kunde samarbeta med konstnären. Förslagsgivaren bör på förhand försäkra sig om att den konstnär som föreslås är intresserad av residens. Om förslagsgivaren inte kommer från Köpenhamn bör i ansökan också finnas förslag om boende- och ateljémöjligheter. Kunstrådets internationella bildkonstkommitté gör utgående från ansökningarna det slutliga valet av konstnärer. Billedkunstcentret å sin sida svarar för administrationen av programmet och för en aktiv programverksamhet med de personer som framfört förslagen. Vid sidan av direktören finns vid Billedkunstcentret nio heltidsanställda personer.

\section{Center for Icelandic Art (CIA), www.cia.is}

Center for Icelandic Art eller på isländska KÍM (Kynningarmiðstöð íslenskrar myndlistar) började sin verksamhet som informations- och marknadsföringscenter för den visuella konsten på Island, men dess uppgift håller redan nu klart på att breddas. Centret har samarbetsprojekt och produktioner med isländska och internationella partners som till exempel ansvar för den isländska avdelningen på följande Venedig-biennal. Dess verksamhet omfattar ett resestipendiumprogram och centret strävar att utveckla det till ett "artist-exchange" program. Numera har CIA internationellt samarbete bland annat med Kunstlerhaus Bethanien i Berlin (www.bethanien.de). Centret har också ett gästprogram för kuratorer, kritiker, konsthistoriker och forskare.

Centret finansieras huvudsakligen av Islands kulturministerium och dess medlemmar är alla centrala aktörer inom de isländska konstinstitutionerna och konstnärsorganisationerna. Vid sidan av Centrets direktör finns en heltidsanställd person. Man håller emellertid för närvarande på att förnya kulturförvaltningens struktur och denna förnyelse torde också komma att påverka CIA:s verksamhet. Man kommer på Island att grunda en motsvarande Kunststyrelse som finns i Danmark och under denna Kunststyrelse kommer att finnas sex kulturråd (musik, litteratur, bildkonst och arkitektur, film samt design). Varje råd kommer att ha sin egen fond och ett eget kontor. En del av fonderna existerar redan nu, som till exempel Bókmenntakynningasjódur för litteratur och Íslenska tónlistarsjódur för musik. En del av fonderna kommer att vara nya, som fonden för bildkonst. Varje kulturråds verksamhet kommer också att omfatta informationsverksamhet och internationella uppgifter. 


\subsection{Residensverksamhet i de nordiska länderna}

Inom bildkonsten existerar en mångsidig residensverksamhet. En av de vanligaste verksamhetsformerna består av gästateljéverksamhet, där konstnären kan hyra både arbetsrum och bostad. I anknytning till residensvistelsen förekommer ofta att konstnärerna har möjlighet att utnyttja de verkstäder och andra tekniska lokaler som finns på orten. Till exempel Kökars konstnärsresidens på Åland erbjuder gästkonstnärerna möjlighet att använda grundskolans mörkrum, Hembygds-muséets smedja och keramikateljé. Skaftfells kultturcentrum i Island erbjuder å sin sida i samband med residensvistelse möjlighet att använda de lokala professionella hantverkarnas olika verkstäder, snickarverkstäder, smedjor med mera.

Konstnären kan också erbjudas en stipendiebostad avgiftsfritt. Konstnären kan få en stipendiebostad som kompensation om han till exempel håller en workshop eller överlåter sitt arbete. Till exempel i Upernavik på Grönland betalar konstnären inte hyra, men det bör arrangeras en öppen verkstad så att lokalbefolkningen kan få inblick i konstnärens arbete. Senast sex månader efter avresan från Upernavik ska konstnären sända ett verk som framställts $i$ anslutning till vistelsen i Upernavik. Verket kommer sedan att ställas ut $\mathrm{i}$ konstnärsbostaden.

Det finns residensverksamhet också i samband med muséer. Till exempel på konstmuséet Rooseum i Sverige finns det på andra våningen två arbetsrum som används för 2-6 månaders ateljévistelse. Enligt Rooseum kan "de gästande konstnärerna använda sitt rum till vad de önskar: kontor, utställningsrum eller andra aktiviteter". Lokalerna är tillgängliga för besökare och ger alla intresserade en chans att möta konstnärerna under deras arbete. Residensverksamheten kan alternativt förverkligas i samband med en verkstad. Den privata Grafisk Vaerkstad på Färöarna fungerar som arbetslokal också för nordiska konstnärer. Grafisk Vaerkstad kan härtill erbjuda en gästbostad.

Många konstnärskollektiv fungerar som gästateljécentra. Till exempel den svenska Konstepidemin drivs av en självständig grupp konstnärer som förfogar över tio byggnader. Den totala ateljéytan är drygt 4000 kvadratmeter. Inom en del residensverksamhet som HIAP i Finland och BAC i Sverige finns program som erbjuder konstnärer en kostnadsfri gästateljé och -bostad och därutöver beviljas vistelsestipendium samt produktionsoch/eller utställningsmöjligheter. En del av residensprogrammen är forskningsinriktade.

Residensverksamheten kan antingen innehållsmässigt eller med tanke på nationalitet vara ytterst noggrant definierad. I Finland koncentrerar sig till exempel Majala Gästateljé främst på samfundsrelaterad konst medan Hollufsgård i Danmark däremot är Nordens viktigaste centrum för skulptur. Till Tapiola residensen som administreras av ateljéstiftelsen för Konstnärsgillet i Finland tar man emot konstnärer från enbart Kanada och Schweiz och till Svolvaer vid Lofoten accepterar man vid sidan av norr- 
män enbart svenskar. Ibland kan gränsdragningarna vara synnerligen skarpa. USF-Verftet i Norge tar som residenskonstnärer emot författare, regissörer och kompositörer från alla nordiska länder utom från Norge. När det gäller bildkonst och konsthantverk tar man emot enbart konstnärer som inte kommer från de nordiska länderna.

Största delen av residensprogrammen tar dock emot nordiska sökande. Men de flesta residensprogrammen verkar fungera utan nätverk eller partners, en del fungerar helt lokalt. Några residensprogram samarbetar dock med de nationella ateljéprogrammen eller är länkade till internationella residensprogram. Residensprogrammens ekonomi är i allmänhet rätt svag och en långsiktig planering av verksamheten är en stor utmaning.

\section{Danmark}

- CRIR, Christiania Researcher in Residence, Köpenhamn, http://crir.homepage.dk

- Danmarks Keramikmuseum Guldagergard, Skælskør, www.ceramic.dk

- Fabrikken for Kunst og Design, Köpenhamn, www.ffkd.dk

- Guestatelier Hollufgård, Odense, www.gah.dk

- Klitgården, Skagen, www.klitgaarden.dk

- Kunstnerhus på Fanø, Sønderho, www.bkf.dk/regado.jsp?type=page\&id $=253$

- Pardo House, Skive, www.krabbesholm.dk/projects/pardohouse/da index.html

- Statens Værksteder for Kunst og Håndværk, Gammel Dok Pakhus, Köpenhamn, www.kum.dk/sw3323.asp

- Storströms amts grafiske vaerksted, Næstved, www.grafisk-kunst.dk

\section{Finland}

Centralkomissionen för konst har nyligen publicerat en utredning, i vilken Riikka Suomi presenterar den internationella residensverksamheten i Finland under åren 1995-2005. Publikationen kom till i samarbete med Ateljéstiftelsen för Konstnärsgillet i Finland. I publikationen presenteras bland annat residensverksamheten för konstnärer i Finland och vilka resurser den kan erbjuda konstnärerna. I publikationen analyseras också residensverksamhetens inflytande på det lokala samfundet och diskuterar verksamhetens framtidsutsikter. Man betonar speciellt ett utvecklande av verksamheten på lång sikt.

I en annan publikation som nyligen utgivits av Centralkommissionen för konst granskar Sari Karttunen det stöd som funnits för konstnärernas mobilitet och gästbostäder under åren 2000-2004. I sektionen för residensverksamhet, som är underordnad Centralkommissionen för konst, kommer man att utnyttja bägge utredningarna då man drar sina slutsatser och gör upp framtida riktlinjer för verksamheten. Sektionen har varit 
verksam sedan 1996 och dess uppgift är att vidareutveckla det internationella konstnärsutbytet i Finland.

Publikationerna har utgivits på finska, men Centralkommissionen för konst som ger ut tidskriften ARSIS har publicerat ett engelskspråkigt temanummer, ARSIS 3/05, som behandlar residensverksamheten i Finland ur många olika synvinklar. Publikationen kan beställas per e-post (tktinfo@minedu.fi).

Förteckningen över residensverksamheten i Finland utgår huvudsakligen från de uppgifter som sammanställts av Ateljéstiftelsen för Konstnärsgillet i Finland.

- AiR - Nykarleby, www.art.syh.filresidence

- AiR Lovisa, http://kotisivu.dnainternet.net/lov-air/index.html

- AiR Pro Artibus, Ekenäs, www.proartibus.fi

- Konstnärsresidens i Kemijärvi, www.kemijarvenkuvanveistoviikot.fi/residenssi_index.htm

- Ateljéstiftelsen för Konstnärsgillet i Finland, www.artists.fi

- Arbets- och semesterbostäder, Oravaniemi och Jesrisjärvi

- Ateljéhus i Helsingfors

- Ateljéhus i Kuopio

- Tapiola Gästateljé, Esbo, www.artists.fi/studio/tapiola.htm

- Ateljé Stundars, Vasa, www.svof.fi/artstundars/

- Ateljéhuset Tuulensuu, Viitasaari, www.tuulensuu.net

- Fågelsångens konstnärsresidens, Helsingfors, www.kulttuuri.hel.fi/elaintarhanhuvila

- Galleri Titanik, Åbo, www.arte.fi

- Gjutars Gästateljé, www.tietovantaa.fi/gm/wl/newsp/vs/spages/tv/taitseur.html

- Helsinki International Artist-in-Residence Program (HIAP), www.hiap.fi

- Enare konstnärsresidens, Enare, www.artslap.fi

- Japan House, Ranua, www.artslap.fi

- Jyväskylä grafikcentrum, www.jkl.fi/kulttuuri/taidemuseo/grafiikkakeskus

- Kolin Ryynänen, Lieksa, www.pktaidetoimikunta.net

- KulttuuriKauppila Ii project, www.ii.fi

- Majala konstnärsresidens, Salo, www.salontaidemuseo.fi

- Mansikkanokka residens, Kemi, www.kulttuurivoimala.com

- Nelimarkka residens, Alajärvi, www.nelimarkka-museo.fi

- Orivesi konstresidens, Orivesi, (ingen hemsida)

- PERiOD - Residens, Nagu, www.peri.fi

- Periodi residens på Nagu, www.peri.fi/projektit.html

- Platform, Vasa, www.platform.fi

- Pori A-I-R, www.uiah.fi/pori

- Portait residency, Björneborg, www.porintaiteilijaseura.fi

- Porvoo Paperart Studio, Borgå, (ingen hemsida) 
- Raumars, www.raumars.org

- Saksala ArtRadius, Haukivuori, www.saksala.org

- Konstcentret Salmela, Mäntyharju, www.taidekeskussalmela.fi

- Santtus Hus, Keuruu, www.keuruu.fi/museo/santuntalo.htm

- Sotka konstnärsresidens, Kankaanpää, http://art.bf.spt.fi

- Stora Räntan, Helsingfors, www.kultuuri.hel.fi/harakansaari/index_se.html

- Residens Sumu , Arte rf, Åbo, http://www.arte.fi

- Tammerfors Studio, www.tampere.fi

- Torgateljéen, Tammerfors, www.tampere.fi/culture

- Viippola I.A.R., Torneå, www.artists.fi/studio/balticsea/viippola.htm

- Vilniemi, Aspas arbetsstuga, Karislojo, www.artists.fi/skjl/vilniemi.html

- Voipaala konstcentrum och barnkulturcentrum, Valkeakoski (ingen hemsida)

Helsinki International Artist-in-Residence Program (HIAP), www.hiap.fi

HIAP som driver sin verksamhet på Kapelfabriken i Helsingfors grundades för sex år sedan i en situation då man lokalt inte hade några andra kontakter till utlandet än de som man fick genom residensverksamheten. HIAP var ett ställe som utländska konstnärer kom till för att arbeta och det centrala i verksamheten bestod av växelverkan, kommunikation, sociala kontakter och skapande av nätverk. Organisationen byggde på att det fanns en person som garanterade och såg till att konstnären kunde skapa de kontakter han behövde. Enligt HIAP har under de senaste åren konstnärernas förväntningar dock förändrats.

HIAP har under hela sin verksamhetstid fungerat på gräsrotsnivå. HIAP befinner sig fortfarande i en situation där endast verksamhetsledaren är anställd och har fast lön. HIAPS:s styrelse arbetar på frivillig basis. HIAP:s verksamhet har från första början haft en ytterst ambitiös konstnärlig målsättning och man väljer vem man vill samarbeta med. De gästande konstnärerna väljs av en jury som utsetts av HIAP. Residensvistelsen är från 2-3 månader i HIAP:s tre ateljéer på ca 50 m2. HIAP betalar åt konstnären ett stipendium på $1000 € \mathrm{i}$ månaden för levnadskostnader. Då det gäller konstnärsutbyte strävar man till att ha jämförbara villkor med sina utbytespartners. För de utländska konstnärerna är ateljén gratis, men de måste själva bekosta sina resor.

HIAP kommer i framtiden att utvidga sin residenskapacitet och vara mera produktionsinriktat samt organisera flera utställningar i samband med residensverksamheten. Utställningarna arrangeras antingen i HIAP:s egna lokaliteter eller så hjälper man konstnären att hitta någon annan utställningslokal. HIAP har nätverkssamarbete med bland annat Bildkonstakademin, Helsingfors Konsthall, Zodiak (Centrum för modern dans), konstnärkollektivet MUU, AV-arkki (ett konstnärslett arkiv för film- och 
videokonst). HIAP har täta inrikeskontakter och har också väckt stort intresse utomlands.

\section{Island}

- Gilfélagiđ, www.listagil.is

- Hafnarborg, www.hafnarborg.is/contact.htm

- Herhúsiđ, www.herhusid.com

- Klaustriđ, www.skriduklaustur.is/ensksida/klaustrid/klaustrid.htm

- Krokur, www.gardabaer.is

- SÍM gästateljé i Reykjavik, www.sim.is

- Skaftfell kulturcentrum, www.skaftfell.is

- Varmahliđ, www.hveragerdi.is

\section{SÍM gästateljé i Reykjavik, www.sim.is}

Nuförtiden förfogar organisationen för bildkonstnärer i Island, SÍM, över två mindre gästateljéer som man hyr ut i centrum av Reykjavik. Hyran är $25000 \mathrm{IKR} / \mathrm{månad}$. SÍM planerar dock att ytterligare utvidga sin residensverksamhet. Ett alternativ för de utvidgade residensaktiviteterna är ett gammalt mejeri på ca 4000-5000 m2. I huset finns redan några arbetsrum för konstnärer och SÍM underhandlar med Reykjaviks kulturnämnd. Hälften av lokaliteterna skulle reserveras för bildkonst och andra hälften för design. Såvida projektet blir verklighet kommer SÍM att förfoga över tre bostäder, tre ateljéer och verkstäder (bland annat för grafik och skulptur), ett seminarieutrymme och en utställningslokal. SÍM skulle hyra ut lokalerna åt såväl isländska som utländska konstnärer. SÍM administrerar tillsammans med Reykjaviks kulturnämnd fonden Muggur, som ger den möjlighet att finansiera isländska konstnärers deltagande i internationella residensprogram.

Norge

- BEK, Bergen Center for Electronic Arts, www.bek.no

- Ekely kunstlerboliger, Oslo, www.oca.no

- Flagfabrikken, senter for fotografi og billedkunst, Bergen, www.flagfabrikken.net

- Gästateljén i Vadsø, Finnmark, www2.finnmark-f.kommune.no/5390.asp

- Hordaland Kunstcenter, Bergen, www.kunstsenter.no

- Kunstnerhuset i Svolvær, Lofoten, www.nnks.no

- Lademoen Kunstnerverksteder, Trondheim, www.l-k-v.no

- Longyearbyen Kunstcenter, Svalbard, www.nifca.org/resi/Cities/Longyearbyen

- Pikene på Broen, Kirkenes, www.pikene.no

- Troms fylkeskulturcenter, Tromsø, troms.kulturnett.no 
- USF Verftet, Bergen, www.usf.no

\section{Sverige}

- Axel Sjöbergs hus, Stockholm (ingen hemsida)

- Baltic Art Center (BAC), www.balticartcenter.com

- Bonniers Konsthall, Stockholm, www.bonnierskonsthall.se

- Konstepidemin, Göteborg, www.konstepidemin.com

- Skulpturateljén Malongen, Stockholm, www.kultur.stockholm.se

- Nordiska Akvarellmuseet, Skärhamn, www.akvarellmuseet.org

- Rooseum, Malmö, www.rooseum.se

\section{Baltic Art Center (BAC), www.balticartcenter.com}

BAC är ett internationellt samtidskonstcenter med särskilt focus på Östersjöregionen. Centret startade sin verksamhet år $2001 \mathrm{i}$ ett gammalt magasin i Visby på Gotland. I sin utställningsverksamhet satsade BAC sedan starten i en hög internationell nivå och koncentrerade sig på platsspecifika nya produktioner. Konstnären erbjöds produktionsresurser och konstnären uppmuntrades till att experimentera under en längre arbetsperiod. Kända konstnärer gjorde enastående verk, som i dag reser runt i världen. Utgående från dessa positiva erfarenheter började BAC utveckla ett eget residensprogram samt blev medlem i ett internationeltt residensnätverk. De senaste två åren har BAC i sin verksamhet koncentrerat sig på residensprogrammet PIR (Production-in-Residence).

Residensprogrammet BAC-PIR har redan under en kort tid visat sig betydelsefullt för den till residensen inbjudna konstnärens konstnärliga produktion. BAC-PIR erbjuder konstnären både en gästateljé och en studio. Programmet vill utryckligen satsa på produktion. Man ser utställningen som en möjlighet att visa det processarbetet som skett under residensvistelsen. Det centrala i programmet är att konstnären erbjuds också produktionsresurser och personal. Man stöder också planeringsprocessen. Vanligvis startar konstnären sitt förberedelsearbete cirka ett år före residensvistelsen och i planeringsprocessen ingår två arbetsresor till BAC. BAC mottar till sitt program PIR tre residenskonstnärer per år.

BAC får många förfrågningar angående nätverkssamarbete, men centret vill själv välja konstnärerna till programmet. BAC samarbetar emellertid med andra lokala aktörer i Visby. I framtiden kommer gränsöverskridande verksamhet att få en större plats $i$ centrets verksamhet. Centrets framtida planer kan också påverkas av att både Riksutställningar och SIDA kommer att flytta till Visby.

\section{Färöarna}

- Fuglafjördur, infoey-f@post.olivant.fo 
- Grafisk verksted, www.art.fo

\section{Grönland}

- Upernavik, www.upernavik.gl

Åland

- Eckerö Post- och tullhus, www.kultur.aland.fi/gastbostad.htm

- Källskär i Kökar (ingen hemsida)

- Kökars konstnärsresidens, www.kokarkultur.com 


\section{Mobilitets- och residensprogram inom litteratur}

Gästhem för författare och översättare är ofta belägna i en litterär omgivning där man också ordnar annat program, i till exempel litteratur- och kurscentra. Det finns gästbostäder för långvarig vistelse tillgängliga $\mathrm{i}$ författarhusen. Största delen av gästhemmen hyr ut arbetsrum för kortvarig vistelse. Gästbostädernas syfte är att garantera författaren arbetsro. Klitgården ja Villa Bergshyddan mottar ansökningar från alla de nordiska länderna. På andra gästhem prioriteras sökande från det egna landet. I fall det finns lediga gästbostäder kan sökande från andra länder få hyra dem. En del gästhem prioriterar sökande vars arbete har anknytning till residensorten. Till exempel i Gunnarshús i Reykjavik ser man gärna personer vars arbete har med Gunnar Gunnarsson att göra.

\section{Danmark}

- Brechts hus, Svendborg, www.svendborg-bib.dk

- Dagny Christensens sommerhus, Ringe (ingen hemsida)

- Hald Hovedgaard, Det Danske Forfatter- og Oversættercenter, Viborg, www.haldhovegaard.dk

- Jeckels hotel i Gl. Skagen, www.timeshare.dk/sider/feriesteder/jeckels.htm

- Julius Bomholts hus “Digterhjemmet”, Sønderho, Fanø (ingen hemsida)

- Klitgården, Skagen, www.klitgaarden.dk

- Kunstnerboligen Gammel Have, Ringe på Fyn, www.gammelhave.dk

- Kunstnerboligene på Hirsholmene, Frederikshavn, www.danskkunstnerraad.dk

- Legatboligen Kongegaarden i Korsør, www.kongegaarden.dk

- Løgumkloster (ingen hemsida)

- Tranebo, Köpenhamn (ingen hemsida)

- ørslev Kloster, www.oerslev-kloster.dk

\section{Finland}

- Författargården Villa Biaudet, Lovisa, forfattarna@kaapeli.fi

- Mellersta Finlands Författarhus, Jyväskylä, www.kirjailijatalo.fi

- Villa Kivi/Läscentrum, Helsingfors, www.villakivi.com 


\section{Island}

- Davíđshús, Akureyri, www.skaldhus.akureyri.is/dshusa.html

- Gunnarshús, Reykjavik, www.rsi.is

- Gästhemmet vid Arnarfjörđur, Isafjörđur, www.rsi.is

- Herhúsid, Siglufjörđur, www.herhusid.com

- Nordurđbær, Einarshöfn, www.rsi.is

- Skriđuklaustur, Fljótsdalur, www.austurland.is/skriduklaustur

- Snorrastófa, Reykholt, www.snorrastofa.is

- Varmahlíđ, Hveragerđi, www.hveragerdi.is

Norge

- Dalanaustet, Haugesund, www.rogaland.fylkesbibl.no/kunstbolig/dalanaustet.html

- Geitungen fyr, Karmøy, www.rogaland.fylkesbibl.no/kunstbolig/geitungen.html

- Obrestad fyr, www.rogaland.fylkesbibl.no/kunstbolig/tilbud.html

- Rogaland kunstnerbolig för författare och andra konstnärer, www.rogaland.fylkesbibl.no

- Voksenåsen, Oslo, www.voksenaasen.no

\section{Sverige}

- Barents Literature Center, Överkalix, http://support2.overkalix.se/ blc/overk.htm

- Danielsgården i Bingsjö, Rättvik, kultur@rattvik.se

- Författarnas Hus, Stockholm, www.forfattarforbundet.se

- Geijerskolan i Ransäter, Karlstad, www.geijerskolan.se

- Internationella gästhemmet, Stockholm, www.forfattarforbundet.se

- Jan Fridegårds sommarhus, Uppsala (ingen hemsida)

- Lissmyr Kesti-gården (ingen hemsida)

- Ruuthska stipendiebostaden på Runmarö, Stockholm (ingen hemsida)

- Salagården i Delsbo (ingen hemsida)

- Sigtunastiftelsens gästhem, Sigtuna, www.sigtunastiftelsen.se

- Villa Bergshyddan, Stockholm, www.kultur.stockholm.se

- Östersjöns Författar- och Översättarcentrum, www.bcwt.org

Östersjöns Författar- och Översättarcentrum, www.bcwt.org

Enligt sin egen beskrivning är Östersjöns författar- och översättarcentrum (The Baltic Centre for Writers and Translators, BWC)

"ett internationellt center för professionella författare och översättare från Danmark, Estland, Finland, Island, Lettland, Litauen, Norge, Polen, Ryssland, Tyskland, Sverige och, i mån av plats, även från andra länder." 
Verksamheten inleddes år 1993 och centret kan erbjuda elva arbetsrum, biblioteket och it-utrustning. Författare och översättare kan på samma villkor söka om ett vistelsestipendium på en månad. Centret har periodvis möjlighet att stöda också resor och uppehälle. Detta är beroende av antalet tilldelade projektstöd samt av bland annat EU-finansiering. År 2004 mottog centralen sammanlagt 202 gäster från 30 länder.

Centret idkar en omfattande programverksamhet, bland annat författarkvällar, författar- och översättarverkstäder, program på bokmässor, symposier samt litteraturevenemang såsom den internationella poesifestivalen på Gotland. År 2005 publicerade centret en utvärdering av sin tioåriga verksamhet mellan 1994 - 2003. Utvärderingen hade gjorts av en utomstående instans. Den är mycket positiv och konstaterar att centret $\mathrm{i}$ sitt slag är enastående och att det inte finns någon motsvarande institution i Norden som på ett liknande eller jämförbart sätt skulle fungera som mötesplats för olika litterära yrken.

Centret har ett representantskap med nio medlemmar, varav en medlem är styrelseordförande för centret. Styrelsen består av sex medlemmar, varav två är representanter för Sveriges författarförbund, två för Länsstyrelsen (varav den ena representerar Gotlands län, och den andra Högskolan) samt två medlemmar från Östersjöförfattarnas råd (Baltic Writers' Council). Centrets chef väljer deltagande författare och översättare för residensvistelserna. Förutom chefen finns vid centret en heltidsanställd och två timanställda personer. En del av servicen är utlokaliserad. Centret har länge försökt få finansiering för sin verksamhet från Nordiska ministerrådet. För närvarande finansieras verksamheten av svenska staten och Gotlands län. Centret hör till det internationella översättarnätverket (www.bon-a-tirer.com/recit) och fungerar som sammankallare av Östersjöförfattarnas råd. 


\section{Mobilitets- och residensprogram inom musik}

Inom musiken känner man inte till begreppet residens i samma bemärkelse som inom bildkonsten. Det finns ett fåtal residens som är i allmänhet ägnade för tonsättare och anslutna till någon musikstudio. Som undantag kan nämnas Miekkaniemi, en residensverksamhet som inleddes senaste år och som riktar sig till utövare av rytmisk musik. Professionella musikutövare har också möjlighet att ansöka om gästbostäder som är menade för författare. Härtill kan de ansöka om residens som är öppna för alla konstområden, som till exempel USF Verftet i Bergen.

Danmark

- Klitgården, Skagen, www.klitgaarden.dk

- Lille skiveren, mellan Skagen och Hirtshals, www.artisten.dk

- Mårup Havn, Samsø, www.djbfa.dk

- Salenegården, Bornholm, www.djbfa.dk

Finland

- Miekkaniemi, Viitasaari, www.kolumbus.fi/miekkaniemi

- Teosto/FIMIC, bostad för komponister, södra Finland, www.fimic.fi

Sverige

- Visby Internationella TonsättarCentrum (VITC), www.centreforcomposers.org

Visby Internationella TonsättarCentrum (VITC), www.centreforcomposers.org

Visby Internationella TonsättarCentrum (VITC) startade sin verksamhet år 2001 och centret är det enda i sitt slag i världen. Centrets verksamhetsidé går ut på att kompositören kan ansöka om stipendium för residensvistelse. Stipendiet består av fri logi och tillgång till studio (pianostudio och elektroakustisk studio) under högst 4 veckor. VITC har i viss mån även möjlighet att ge bidrag till resor och levnadskonstnader. Kompösitörer kan ibland också inviteras till residensen. I sådana fall har centret vanligtvis samarbetat med andra parter, som till exempel NOMUS som kan beställa ett nytt verk av kompositören. Centret har också samarbetat med 
Svenska Rikskonserter då det rört sig om kompositörer från Balkan. Med Svenska Institutet har centret samarbetat då det gällt kompositörer från Ryssland och Ukraina. Samarbetspartnern har i allmänhet ansvarat för den inbjudna kompositörens resor och dagtraktament.

Centret kan erbjuda en enastående miljö för en kompositör i residens. I centret arbetar samtidigt alltid tre kompositörer från olika håll i världen. Centret har tagit emot kompositörer från över 40 länder och bland dessa finns också några nordiska kompositörer. Cenret har samarbete med Gotlands tonsättarskola som är belägen i samma byggnad och den har i begränsad omfattning program som är öppna för publik. Utöver residensverksamheten har centret också övrig internationell verksamhet. Centret är bland annat medlem i International Society of Contemporary Music.

Centrets styrelse på fem personer består av centrets direktör samt en representant för Gotlands kommun, Gotlands landsskapsstyrelse, Föreningen Svenska tonsättare och Gotlands medborgarinstitut. Valet av konstnärer fattas av en grupp på tre personer; centrets direktör, centrets studiochef och styrelsens ordförande. Som en av sina verksamhetsprinciper betonar man att centret inte fungerar som "stilpolis" utan att dess uppgift är att erbjuda kompositörer faciliteter och verksamhetsmöjligheter. I framtiden är centret intresserat av nya tvärkonstnärliga samarbetsformer, exempelvis på så sätt att en libretist, koreograf och bildkonstnär kunde samarbeta med en kompositör. 


\section{Mobilitets- och residensprogram inom scenkonst}

Begreppet residens andvänds inom scenkonst inte i samma bemärkelse som inom bildkonst. När det inom scenkonst talas om residenser så menas det ofta ett "arbete i process" (Work-in-progress). Residensverksamheten är då kopplad till en produktionsmiljö. Det finns bl.a. så kallade gästspelsscener för dans. Den gästande huskoreografen arbetar ensam eller tillsammans med en ensemble. Vanligvis slutar processen i en offentlig föreställning. I Norden finns det tills vidare mycket litet av den här sortens organiserade och produktionsbaserade residensverksamhet. Men till exempel inom dans har många koreografer möjlighet att från sitt hemland ansöka om stöd för internationell residensvistelse. Nationellt finns det också stöd som möjliggör att unga dansare kan delta i internationella verkstäder och festivaler.

För närvarande planerar man i Sverige att skapa ett eget "IASPIS" för danskonst. Med hjälp av det nya programmet skall koreografer ha möjlighet till långvariga vistelser och ett produktiosbaserat arbete. Det är också meningen att man med hjälp av programmet skall kunna skapa kontakter till internationella danscentra och -nätverk. Programmet kommer att erbjuda ett forum för ny koreografi. Programmet torde komma att ta exempel från Paris, där Centre National de la Dance driver ett internationellt studioprogram som inkluderar 11 studior och ett videotek.

I Finland kommer det regionala danscentret $i$ väst att från och med år 2007 starta ett mästarresidens i koreografi i Åbo. Residenset kommer att ha en öppen ansökan. I residensstipendiet kommer att ingå boende, repetitionsutrymme och lön under residensvistelsen. Residensvistelsens längd kommer att vara 2-3 månader. Också Jo-Jo, Danscentret i Uleåborg, planerar att starta residensverksamhet från och med år 2007.

\section{Danmark}

- Dansescenen, huskoreograf, www.dansescenen.dk

- Huskoreograf, talentpleje inden for moderne dans, www.kunststyrelsen.dk

- Huskoreografer, www.dansevidesnkab.ku.dk

- Kulturhus Århus, www.kulturhusaarhus.sk

- Moderne dans på turne, www.dansenshus.dk 


\section{Finland}

- Villa Marketta \& Manu, Pyhäsalmi, www.fullmoondance.fi

Norge

- BIT Teatergarasjen, Bergen, www.bit-teatergarasjen.no

- Black Box teater, Oslo, www.blackbox.no

- Teaterhuset Avantgarden, Trondheim, www.avantgarden.no

- DTS, Dance og teatersentrum i Oslo, www.scenekunst.no/dts

- SFD, Senter for Dansekunst i Oslo, www.dance.no

\section{Sverige}

- Dansnät Sverige - residens, gästspelscen, huskoreograf, www.dansnatsverige.se

- Dansstationen, Malmö, www.dansstationen.nu

- Pustervik - gästspelsscen, Göteborg, www.pustervik.goteborg.se 


\section{Mobilitets- och residensprogram i regi av Nordiska ministerrådet}

\subsection{Nordiskt institut för samtidskonst (NIFCA)}

NIFCA's nuvarande residensprogram har långa traditioner. Gästateljéverksamheten med egna ateljéer inleddes redan år 1982 som en del av Nordiska konstcentrets verksamhet. Verksamheten utvecklades på 1990talet så att NIFCA för gästateljéverksamheten förhandlade om samarbetsavtal med nordiska och baltiska gästateljéer. De senaste fem år har NIFCA inriktad sin gästateljéverksamhet mer som ett prosessiorienterat residensprogram, i vilket NIFCA som värdorganisation samarbetar med gästande konstnärer. I sitt huvudprogram Nordic Air har NIFCA årligen förverkligat ca 100 residensmånader för professionella konstnärer från Norden, Baltikum och nordvästra Ryssland. I år 2006 samarbetar NIFCA med följande partners i Nordic Air:

- Art Home, Konstnärsförbundet (Lettland)

- Eckerö Post- och tullhus (Åland)

- Fuglafjördur Residens (Färöarna)

- Hafnarborg (Island)

- Hollufgård (Danmark)

- Hordaland Kunstsenter (Norge)

- IASPIS (Sverige)

- Konstepidemin (Sverige)

- Konstnärsförbundet (Estland)

- Konstnärsförbundet (Litauen)

- Koppelo (Finland)

- National Centre for Contemporary Art (Ryssland)

- Nýlistasafniđ (Island)

- Pikene på Broen (Norge)

- Pro Arte Institute (Ryssland)

- Rooseum (Sverige)

- Upernavik (Grönland)

NIFCA's alla residenser omfattar en studio eller möjlighet till arbetsutrymme. Härtill kommer bostad, ett månatligt stipendium på $840 €$, presentation av konstnären på NIFCA's hemsida samt möjlighet att knyta kontakter och delta i olika aktiviteter. 
Från år 2000 har NIFCA arrangerat ett residensprogram också för kritiker och kuratorer och de har årligen erbjudits ca 10 residensmånader. NIFCA har årligen förverkligat också ca 50 residensmånader genom olika kortvariga tematiska residensprogram, vars tema har grundat sig i Nordiska ministerrådets politiska prioriteringar. I tematiska residensprogram har man ofta koncentrerat sig på vissa geografiska områden. Till exempel programmet Network North förverkligades i Skotland-Nord-Irland, VestBalkan och Nord-Västra Ryssland. NIFCA:s tematiska residensprogram har också ibland kunnat omfatta ett tematiskt innehåll som Nordiska ministerrådet prioriterat, som exempelvis nya media. I det bilaterala programmet Global Respectives finns alla residenser utanför Europa. År 2006 samarbetar NIFCA med residensverksamhet i Beirut, Buenos Aires, Kairo, Shanghai, Singapore och Yangon. Programmet Global Perspectives har arrangerats sedan år 2002.

På Sveaborg disponerar NIFCA $2558 \mathrm{~m} 2$ lokaler som är kvalitativt utrustade och renoverade och som värdlandet har ställt till disposition utan vederlag. Sveaborg ligger söder om Helsingfors i skärgården, ca 1,5 km från Helsingfors salutorg. Sveaborg har ett historiskt värde. Fästningen grundlades 1748 av svenska kronan och hör sedan 1991 till Unesco förteckning över Världsarv. Sveaborg är också ett av Finlands viktigaste turistmål och ön besöks årligen av ca. 650.000 personer. Byggnaderna på Sveaborg förvaltas, renoveras och uthyrs av Sveaborgs förvaltningsnämnd, som står under Undervisningsministeriet. Förvaltningsnämnden betraktar kulturinstitutioner som lämpliga hyresgäster. Konstskolan Maa fungerar på ön och Helsingfors konstnärsförening har hyrt de utställningslokaler i Strandkasernen som tidigare disponerades av Nordiska konstcentret.

NIFCAs lokaler ligger på Vargholmen, som utgör centrum i ögruppen Sveaborg. Sveaborgs förvaltningsnämnd beskriver NIFCAs lokaler så här:

"Kontorslokalerna och Galleri Augusta ligger i en kasern (B 28) från år 1860. Kasernen renoverades för Nordiska konstcentret i början av 1980-talet. Lokalerna är fortfarande representativa och i gott skick.

Ateljéerna och gästrummen ligger i Bastionen Palmstierna (B 42). När byggnaden renoverades för att rymma ateljéer och gästrum byggdes vinden om och rymmer nu de bostäder som är kopplade till ateljéerna.

Institutets huvudbyggnad (B 28) renoverades på 1980-talet och då inrättades utställningslokaler för Galleri Augusta. Galleriet används inte längre för utställningar, men NIFCA arrangerar seminarier och möten i utställningslokalen. Sveaborgs förvaltningsnämnd har själv bruk för Galleri Augustas utställningslokaler och kommer att hyra ut galleriet till konsthantverk.

NIFCA disponerar dessutom fyra lägenheter. Tre av dessa ligger vid Fästningens central-skvär i det hus som kallas Platsmajorens hus, ett av ön mest värdefulla byggnader. En lägenhet finns i samma hus som NIFCAs kontor och har använts av NICFAs vaktmästare. För en del av lägenheterna betalar innevånarna hyra." 
Angående lokalernas arealer och fördelning finns det en särskild bilaga (bilaga 5.).

Det har ofta varit diskussion om NIFCAs tillgänglighet. Ibland har NIFCA upplevt att de är "långt borta på en ö" och det har också funnits planer på att flytta bort från Sveaborg. Sveaborg har goda trafikförbindelser och Sveaborgs förvaltningsnämnd beskriver dem på följande sätt:

\footnotetext{
"Sveaborg är en ö och trafiken från och till ön sköts med färjor. Persontrafiken ingår i Helsingfors stads trafikverks nät och fungerar med dess tariffer. På ön finns det ca 350 bostäder (ca 900 helsingforsare bor på ön) och 400 arbetsplatser. Färjtrafiken fungerar hela året och dygnet (på natten mellan kl 02- 06 är det paus i trafiken). Överfarten med färja tar ca 15 minuter. Färjan kan också ta bilar och paketbilar. Färjtrafikens hamn finns på Stora Svartholmen och härifrån är det ca 1 $\mathrm{km}$ till NIFCAs lokaler. En färja i servicetrafiktrafikerar dagligen mellan Skatudden och den stranden på Stora Svartholmen. Servicefärjan kan ta 90 ton (långtradare i full last). I princip är Sveaborg ett bilfritt område och den interna trafiken sköts med lätta fordon. Servicetransporter och transport av byggnadsmaterial är dock tillåtet."
}

\subsection{Resestipendieprogrammet Sleipnir}

NIFCA har också administerat Sleipnir, Nordiska ministerrådets resestipendieprogram för unga professionella konstutövare i Norden. Sleipnir har haft som målsättning att öka rörligheten bland yngre konstutövare och uppmuntra till verksamhet i Norden och dess närområden. Genom Slepnir har ca 300000 EUR delats ut varje år. Stipendierna har beviljats av en sakkunnigkommitté utsedd av Nordiska ministerrådet. Kommittén har bestått av representanter för NordScen, Nomus, Nordisk Film- \& TV Fond - NFTF, Nordbok och NIFCA. Ansökningarna har behandlats var fjärde vecka. År 2004 beviljades allt som allt 443 resestipendier.

Sleipnir stipendierna har varit personliga resestipendier. Ansökningen har varit öppen för professionella konstutövare i Norden under 36 år och omfattat alla konstområden: teater, dans, bildkonst, design, arkitektur, musik, film, litteratur och tvärkonstnärliga. Med professionell konstutövare har man avsett genomförd konstnärlig utbildning och/eller dokumenterad yrkesverksamhet. Sleipnir har vanligtvis inte beviljat stipendier åt studerande som inte slutfört sina studier.

Sleipnir har beviljats för resor inom Norden, men utanför det egna landets gränser, samt från Norden till de östra närområdena. Till de östra närområdena räknas Estland, Lettland, Litauen och Rysslands nordvästra delar. Sleipnir har möjliggjort finansiering av resekostnader och andra kostnader i anslutning till resan, såsom boende, levnadskostnader, eventuella kursavgifter osv. Sleipnir har inte finansierat direkta projektkostnader som inköp eller transport av material eller produktion av konstverk. 
Sleipnir har prioriterat 1) kontaktskapande och nätverksbyggande resor, deltagande vid evenemang med relevans för den egna konstnärliga verksamheten, 2) fortbildning och forskning med relevans för den egna konstnärliga verksamheten och 3) andra resor med stor vikt för den egna konstnärliga verksamheten som inte är arbetsresor med avtalad lön. Vid sidan av dessa allmänna kriterier har de sakkunniga i praktiken också använt sig av mer specifika betoningar inom sina egna konstområden. Med hjälp av Sleipnir har man ofta gett stöd också för residensvistelser.

Konstnärer som bor i de baltiska länderna eller i nordvästra Ryssland har ansökt om Sleipnir-stipendier via Nordiska ministerrådets informationskontor i Estland, Lettland, Litauen och Ryssland. Resestipendier har beviljats även för kuratorer, kulturredaktörer och konstforskare. Från och med år 2001 har de nordiska informationskontoren i Baltikum erbjudit resestipendier också för kulturförvaltare genom programmet "Closer Culture Neigbours". År 2005 utdelades totalt 70000 DKK åt sju stipendiater. Summorna är inte stora men programmet har varit en framgång. Med hjälp av det har man kunna sända iväg "det bästa av de bästa". Sleipnir verkar också för övrigt att fungera bra i Baltikum. Enligt de nordiska informationskontoren är ansökningarna på hög nivå, programmet är relativt väl känt och administreringen av programmet sköts flexibelt. Det är också av stor vikt att ha kännedom om lokala informationsmöjligheter. Sleipnirstipendiet erhålls årligen av ca 60-85 personer per informationskontor för en sammanlagd summa på ca 1,5 miljoner DKK.

I de samtal som jag fört har man ofta kritiserat det faktum, att man i Sleipnir satt en övre åldersgräns på 36 år som ett ansökningskriterium. Många har konstaterat att det inom konstfältet är en trend att konsten "föryngras" och undrat över varför man vill stöda den här utvecklingen också med nordiska medel. I samtalen kom det också fram önskemål om att stipendieordningar som rör kultursamarbete, såsom Sleipnir, borde förändras $i$ en sådan riktning att balterna inte längre skulle ha ett separat program utan kunna ansöka i samma program som nordbor. Man åller som bäst på att förnya programmet Nordplus så att det öppnas för balter på samma villkor som för nordbor. Från och med 2007 kommer de baltiska länderna att själv betala sin andel i det nya baltiskt-nordiska programmet. Detta beslut har föregåtts av en avancerad diskussion med myndigheterna och ett politiskt beslut i saken.

\subsection{Nordiskt Center för Scenkonst (NordScen)}

I NordScens verksamhet ingår residensprogrammet Nordic Resort. Residensprogrammet startades år 2004 och programmet riktar sig till aktiva, professionella nordiska scenkonstnärer och akademiker. Det forskningsbetonade programmet förverkligas i samarbete med nordiska scenkonstskolor och opera-akademier. NordScen har som mål att förverkliga 
de 1 - 4 långa residensvistelserna individuellt. Enligt NordScen skall programmet

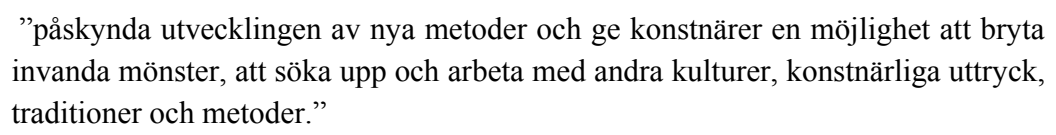

NordScen har planer på att också teaterinstitutioner i framtiden kunde vara samarbetspartners i programmet.

NordScens projektchef väljer deltagarna i programmet i samarbete med de mottagande värdorganisationerna. Senast inkom 60 ansökningar varav nio deltagare blev valda på basen av deras projektplan. Det var andra gången som ansökningsrundan arrangerades. NordScen beviljar deltagarna i programmet ett vistelsestipendium på $600 € /$ månad och ett boendestöd på $300 € /$ månad samt resekonstnader för deltagare över 36 år (deltagare under 36 år har rekommenderats att ansöka om ett Sleipnirstipendium). Den mottagande värdorganisationen skaffar en hyresbostad och ansvarar för de lokala arbetsförhållandena. I Finland har programmets deltagare kunnat bo i NIFCA's ateljéutrymmen på Sveaborg. Förutom för konstnärernas stipendier har NordScen också ansvarat för projektichefens lön och programmets administration. För år 2006 har man för programmet budgeterat ca $650.000 \mathrm{DKK}$, men den här summan inkluderar ännu inte löne- och administrationskonstnader.

Förutom residensprogrammet Nordic Resort har NordScen också satsat på många andra program vars syfte varit att uttryckligen stöda personers moblitet, inte verkens. Många av dessa program har omfattat verkstäder, föreläsningar och symposier. NordScen har också skapat virtuella mötesplatser som www.scenerum.org.

\subsection{Nordiskt konstnärscenter Dalsåsen (nkd)}

Nkd ligger i Dale, en liten stad med 1300 invånare. Resan från Bergen till Dale tar ca tre timmar med bil och båt. En känd norsk arkitektbyrå har planerat centrets utrymmen speciellt med tankte på residensverksamhet. Centret omfattar ett kombinerat verkstads-studioutrymme på $670 \mathrm{~m} 2 \mathrm{och}$ identiska, internet-kablade ateljéer på $50 \mathrm{~m} 2$. Centret har därtill tekniska utrymmen och utrustning, såsom mörkrum, tryckpress, videoeditering, lagerutrymmen $\mathrm{mm}$. Centrets läge möjliggör också arbetet ute. Centret förfogar också över en privat donaterad villa. Villan används som konstnärernas gemensamma utrymme och för administrationen. Konstnärernas förfogar härtill över fem bostader med 1 - 3 sovrum. I närheten finns också en fyr, en liten gäststuga och en bondgård som konstnärerna kan hyra via centret. I bondgården finns också arbetsrum för musiker och kompositörer. 
Centret har sedan starten 1998 drivits som en stiftelse. Nordiska ministerrådet har finansierat $2 / 3$ av verksamheten (löner, administration, verksamhet) och norska staten $1 / 3$ av verksamheten (fastigheter och deras underhåll). NIFCA's styrelse har administrerat också Dalsåsen. Årligen har centret delat ut ca 19 konstnärsstipendier för residensverksamhet. Stipendiet täcker reskostnader, materialstöd på 3000 NOK och ett vistelsestipendium på 3700 NOK. Centret har årligen mottagit ca 230 residensansökningar men år 2006 fick centret ta emot över 400 ansökningar.

Cirka $80 \%$ av konstnärerna som kommer till centret är från Norden och ca $20 \%$ är internationella gäster. De gästande konstnärerna arbetar ofta med hantverk, design, arkitektur eller videokonst. Många arbetar med träd som material. Konstnären har erbjudits arbetsutrymmen och arbetsro, men centret har också försökt ge konstnären möjlighet att presentera sitt arbete. Som en väsentlig del av centrets verksamhet ingår olika samarbetsprojekt i centrets närområde, seminarier, verkstäder, utflykter och studieresor, för att bl a bekanta sig med utställningsutbudet i Bergen. Vanligtvis är residensvistelsens längd mellan 3 - 12 månader.

I nårområdet har centrets konstnärer samarbetat med bland andra Fjalers lekskola Elvetun, grundskolan Dingemoen och det internationella gymnasiet Red Cross Nordic United World College. Dalsåsen har också samarbetat med kulturcentret Kulturbeiten i Dale, som har gästrum för författare och journalister. Till Dalsåsens lokala samarbetspartner hör också Sogn og Fjordane Kunstmuseum i Førde, Høgskolen i Sogn og Fjordane, Kystmuseet i Florø, Vevang produksjon i Dale och Innvik ullevarefabrikk, där man håller utställningar och verkstäder på sommarn. Tvärkonstnärliga Måre biennal i Sognefjord och den internationella bildkonstutställningen Vevring är också viktiga lokala partners. I Bergen har Dalsåsen samarbetat med bl a Kunsthøgskolen i Bergen, BAS Bergen Arkitektskole, Galleri 3.14, Bergen kunsthall, BIT Teatergarasjen och Sparbanken Vest.

\subsection{Skandinaviska föreningen i Rom}

Skandinaviska föreningen i Rom beskriver själv sin residensverksamhet med begreppen "studieställe och studievistelse". I praktiken betyder verksamhetsidén att ca 50 nordiska konstnärer årligen har möjlighet att vistas i en förmånlig miljö/arbetsrum i Rom. År 2005 kostade dubbelrum $390 €$ per månad och ett enkelrum $310 €$. Skandinaviska föreningen i Rom kan hyra ut fyra rum för en period som sträcker sig från 1-4 månader. I föreningens lokaliteter finns också gemensamma utrymmen, som en salong, ett bibliotek, en matsal och ett kök. Som bäst förhandlar föreningen om en ny lokal som skulle möjliggöra uthyrning av fem rum.

Verksamhetsidén grundar sig å ena sidan på att konstnären erbjuds en anonym tillvaro och arbetsro, möjlighet att bli inspirerad av sin vistelse i 
en främmande stad. Å andra sidan vill man uppmuntra tvärkonstnärliga, möten mellan olika konstarter. Man betonar växelverkan, nätverk och sociala relationer. Platsen har också fungerat som ett slags kulturcenter och arrangerat publika arrangemang. I mån av möjlighet har föreståndaren på konstnärernas begäran ordnat kuratorstöd, lokala möten eller studiebesök.

Platsen har ansökningstid en gång per år. De nordiska konstnärsorganisationerna prioriterar i sitt eget land ansökningarna inom det egna konstområdet. För en utomstående blir det inte klart enligt vilka kriterier konstnärsorganisationerna sammanställer sina förslag, men ansökningarna uppger information om den sökandes utbildning, konstnärliga verksamhet och syftet med vistelsen. Föreståndaren schemasätter och delar ut studieplatserna i enlighet med konstnärsorganisationernas förslag. Man strävar till att de gästande konstnärerna representerar olika konstarter och kommer från olika länder.

Enligt nuvarande stadgar skall häften av de årliga gästerna representera bildkonstnärer och det här avspeglas också i ansökningssiffrorna. Ur dem framgår det också tydligt att konstnärerna nationellt har mycket olika möjligheter att ansöka om stöd för sitt studiebesök. Till exempel varje vistelse av en norsk bildkonstnär stöds med 15000 NOK av Bildkonstnärsförbundet i Oslo. Två danska konstnärer har i sin tur årligen möjlighet att för sitt studiebesök få stipedium från Tuborgsfondens konstnärslegat.

Styrelsens roll är administrativ och den ansvarar juridiskt för platsens ekonomi. Men hjälp av Nordiska ministerrådets bidrag betalas hyran och föreståndares lön. Styrelsen består av de nordiska ambassadörerna i Rom samt direktörerna för de nordiska institutionerna i Rom.

\section{6 Övrig verksamhet i samband med mobilitet}

Nordiska litteratur- och bibliotekskommittén Nordbok har årligen finansierat mobilitet genom tre olika stödformer. Folkbiblioteken i Norden har kunnat ansöka om stöd för rese- och boendekostnader till författargäster. Nordbok har för detta ändamål årligen utdelat ca 200000 NOK och med detta belopp har man kunnat finansiera ca 10 besök per år. Härtill har Nordbok årligen delat ut ca 25.000 NOK i rese- och boendekonstnader till översättare som arbetar med små språk. Med detta belopp har man kunnat finansiera 2 - 3 besök per år. Också största delen av Nordboks projektstöd har användts till rese- och boendekostnader. Nordbok har bl a årligen beviljat ca 500.000 NOK i projektstöd för folkhögskolan BiskopsArnö. Detta har möjliggjort att ca 70 författare årligen kunnat delta i folkhögskolans författarkurser.

Också Nordiska musikkommittén NOMUS har finansierat verksamhet som ökar mobilitet. Nomus har årligen utdelat stöd för sammankomster 
och nätverk. Summorna har dock inte varit särskilt stora. Under åren 2001 - 2005 beviljades totalt 2 milj. SEK (dvs. cirka 240000 SEK/år) för detta ändamål. Men för dessa stödformer ansöktes allt som allt 7,4 milj. SEK (=ca 1,5 milj. SEK/år). Nomus har haft planer på att i större utsträckning stöda uppkomsten av nätverk. Den har bland annat börjat planera stöd för ett nordiskt nätverk som skulle bestå av 20-30 ledande jazzarrangörer. 


\section{Internationella residensnätverk}

\subsection{Res Artis, www.resartis.org}

Res Artis (Worldwide network of Artists residencies) är världens största nätverk för residensprogram. Nätverket representerar över 200 centra och organisationer i över 50 länder. I sin verksamhet koncenterade sig Res Artis tidigare på Europa och USA, men nuförtiden har verksamheten expanderat till Asien. Som bäst håller Res Artis på att expandera sin verksamhet också till Afrika och Syd-Amerika. Res Artis fungerar som ett öppet nätverk för alla konstområden. I nätverket finns många olika typer av medlemskap, men alla medlemmar betalar en medlemsavgift som baserar sig på organisationens storlek. Det här möjliggör att medlemmarna i Res Artis består av allt från personmedlemmar och konstnärsgrupper till stora residensprogram och organisationer. På ett årligt tematiskt möte bekantar sig medlemmarna med värdlandets/landsdelens verksamhet, delar erfarenheter och letar efter samarbetespartners.

Vid sidan av personliga kontakter uppskattas Res Artis' hemsidor, till vilka alla medlemmar kan förmedla information om sin residens. På hemsidorna hittar man uppgifter om andra internationella residensnätverk, som till exempel Triangle Art Trust (fokus på utbyte av idéer och samarbetsmöjligheter), RAIN Artists' Initiatives Network (fokus på Afrika, Asien och Syd-Amerika) och European Forum of Art and Heritage (fokus på kulturpolitisk utveckling i Europa). På hemsidorna presenteras också finansieringmöjligheter och andra informationskällor. Två gånger per år publicerar Res Artis också en medlemsbulletin.

Även om Res Artis fungerar med en medlemsavgift så kan medlemskapet i nätverket ändå berätta något om residensverksamhetens stabilitet. Res Artis har 19 nordiska medlemmar. Också NIFCA och Nordiskt konstnärscenter Dalsåsen är medlemmar i Res Artis.

Norge

- Lademoen Kunstnersverksteder

Danmark

- Dansk Kunstnerråd

- Fabrikken for Kunst og Design 


\section{Sverige}

- BAC, Baltic Art Center

- IASPIS

- Konstepidemin

Finland

- Ateljéstiftelsen för Konstnärsgillet i Finland

- Galleri Nunes

- Helsinki International Artist-in-Residence Programme HIAP

- Institutet för vuxenutbildning

- Kemijärvi Skulptur

- Kökars konstnärsresidens

- Kolin Ryynänen - konst- och kulturcentrum

- Kulturstiftelsen Arte ry.

- Nelimarkka residens/museum

- Raumars

- Saksala ArtRadius

- Salo konstmuseum Veturitalo

- Stiftelsen Pro Artibus

\subsection{Trans Artists, www.transartists.nl}

Trans Artists (The world's main information centre for artists or artist-inresidence opportunities) är en världsomfattande informationskanal som på sin hemsida presenrerar aktuell ansökningsinformation om residenser och som informerar om stipendiemöjligheter, nya publikationer etc. Trans Artists fungerar också som rådgivningskanal, där man kan be om råd till exempel då det gäller val av residens. Trans Artists publicerar också en mer redaktionell och avgiftsbelagd tidskrift. I den presenteras konstnärernas erfarenheter från olika residenser och $\mathrm{bl}$ a residenser i olika landsdelar. Trans Artists arrangerar på beställning workshops, där det presenrerar residensmöjligheter. Trans Artists har 40 nordiska medlemmar och också Nordiskt konstnärscenter Dalsåsen är medlem i Trans Artists.

Norge

- Hordaland Kunstcenter

- Lademoen Kunstnerverksteder

- Longyearbyen Kunstcenter

- USF Verftet/ Stiftelsen kulturhuset 


\section{Danmark}

- Brechts hus

- Danmarks Keramikmuseum Guldagergard

- Fabrikken for Kunst og Design

- Hald Hovedgaard, Dansk författer- och översaettarcenter

- Hollufgård

- Pardo House

- Statens Værksteder for Kunst og Håndværk, Gammel Dok Pakhus

\section{Sverige}

- BAC, Baltic Art Center

- Konstepidemin

- Kunstnerhuset i Svolvaer

- Nordiska Akvarellmuseet

- Östersjöns Författar- och Översättarcentrum

- Visby Internationella TonsättarCentrum

\section{Finland}

- AiR Lovisa

- Ateljé Stundars

- Ateljéstiftelsen för Konstnärsgillet i Finland

- Enare konstnärsresidens

- Galleri Titanik

- Jyväskylä grafikcentrum

- Konstnärsresidens i Kemijärvi

- Kuopio gästateljé

- Kökars konstnärsresidens

- Majala konstnärsresides

- Nelimarkka residens

- Oulunkylä studioateljé

- Porvoo Paperart Studio

- Raumars

- Saksala ArtRadius

- Tapiola Gästateljé

- Viippola I.A.R.

- Zodiak

\section{Island}

- Gilfélagiđ

- Hafnaborg

- Klaustriđ

- SÍM gästateljé 
- Skaftfell kulturcentrum

8.3 On the Move, www.on-the.move.org

Informal European Theatre Meeting (IETM) är en förening som består av europeiska festivaler, gästspelscener, turnerande grupper och organisationer som befrämjar internationellt utbyte inom teater- och danskonst. Föreningen fungerar som ett nätverk och den arrangerar möten av vilka de största är de årliga arrangemangen Annual Meeting ja Members Forum. Webbsidan On the Move föddes inom IETM för några år sedan, men numera är On the Move en självständig organisation som finansieras med EU-stöd. On the Move upprätthåller en nyhetsservice och en portal som innehåller aktuell information om bland annat finansieringsmöjlligheter. On the Move publicerar också artiklar om aktuella teman, som till exempel beskattning. On the Move har också specialiserade utbildare i mobilitet som i sin tur utbildar nya utbildare av medlemmar i olika länder. Ett av utbildningsämnena behandlar frågan hur man kan förminska hindren för mobilitet. 
DEL III: Nuvarande läge och behov 


\section{Definitioner av begreppet mobilitet}

Enligt IFACCA finns det geografiska skillnader i begreppet moblitet, till exempel "...the expression "mobility" is not widely used at present outside Europe in the context of the movement of artists across national borders." Därför är det relevant att veta hur den nordiska konstnärsmiljön uppfattar begreppet och hur användningen av begreppet skiljer sig inom olika konstområden.

\subsection{Bildkonst}

- Att byta tankar, metoder och åsikter emellan människor på samma branch i olika länder. Det kan hända genom brev, internet, mötar och residens programmer.

- Det afgørende er at man videreudvikler de kontaktflader der er i mellem de lokale kapaciteter, de nordiske brugere og den internationale kunstscene. Et residency er det mest naturlige regi for udveksling af information på et internationalt niveau, for diskussioner, seminarer, møder mellem kunstnere, kuratorer, kritikere og andre relevante aktører. Ved at trække internationale kuratorer og museumsfolk op som gæster i korte perioder skaber man et fantastisk grundlag for internationale eksponering af nordiske kunstnere. De faglige møder vil være stærkt stimulerende for udviklingen i og kendskabet til Norden.

- För arkitekter kunde mobilitet innebära möjlighet att jobba och studera utomlands (typ som i Villa Lante).

- Gränsöverskridande fri mobilitet för konstverk samt konstnärer, artist-in-residencies, samarbete med utländska konstorganisationerna, gallerier, och konstnärsföreningar.

- Informationer via netværk, rejser og studieophold/workshops, udvekslinger, invitation af udenlandske kapaciteter.

- Mobilitet innebærer for meg både en evne og mulighet til å vise kunstneriske arbeid ulike steder i verden, samt også som kunstner kunne reise og oppholde seg på ulike steder i verden for å arbeide. Begge disse momentene kan ikke realiseres uten en økonomisk og politisk basis.

- Mobilitet innebär att det finns pengar att söka för resor och logi.

- Moblilitet for kunsthåndverkere betyr både å ha råd til å reise et sted og til å la seg inspirere til nye rettninger i sine arbeider. Det kan både 
dreie seg om reise til utstillinger der de delta eller om studie reiser til andre land eller høyskoler.

- Rörlighet och internationella kontakter för konstutövare.

- Våra medlemmar verkar som illustratörer och grafiska formgivare. Mobilitet för vårt yrkesområde är giltigt i kontakt med uppdragsgivaren för att mötas och förstå dennes intention. Eftersom vi ägnar oss åt att visualiser intentioner.

- Vara möjligast rörlig och kunna resa runt och besöka ett flertal platser. Ha möjlighet att bekanta sig med bildkonstnärer i andra länder och skapa kontakter. För isländska bildkonstnärer är det mycket viktigt att kunna delta i utställningar utomlands.

\subsection{Litteratur}

- Att författare och översättare med olika specialintressen bereds möjlighet att besöka och vistas i de länder de har behov av. Det kan även vara i form av öppna arbetstipendier som bereder tillfälle till spontana möten och kontakter ungefär som det fungerar på Halds Hovedgård i Danmark eller på författar- och översättarcentret i Visby.

- För översättarna innebär mobilitet närmast möjlighet att arbeta i de länder vars språk man översätter från. Ett exempel på mobilitet är översättarnas möjlighet att använda författar- och översättarcentren i olika länder. Deltagandet i branschens internationella evenemang är också en del av mobilitet. Några exempel på sådana evenemang är kongresser, seminarier, kurser och verksamhet inom olika länders översättarorganisationer samt i samarbetsorgan.

- Mulighet til å reise og orientere seg i andre lands (nabolandenes) litteratur og dramatikk, og å knytte kontakt med forfattere og oversetterkolleger; faglig og språklig oppdatering.

\subsection{Musik}

- DAF repræsenterer især rytmisk musik, cirkus- og estradkunst samt visse genrer inden for dans, med mere. Inden for vore områder betyder mobilitet flere ting, f.eks.: Villighed til at rejse, evne til indlevelse i andre kulturer, evne til at bruge nye indtryk til ny kreativitet, evne til samarbejde.

- Festivaler, konserter, kompositionsbeställningar, operaprojekt, workshops, seminarier och residensverksamhet.

- För en tonsättare kan begreppet mobilitet innebära två helt olika saker: 1. mobilitet av tonsättaren som person. Att resa och dela med sig som instuderare, lärare m.m. eller att uppehålla sig i annan miljö 
för förkovran och inspiration. 2. mobilitet av tonsättarens verk. Att det sätts upp eller spelas av annan institution eller att den uppförande ensemblen får möjlighet att turnera med verket ex. till annat nordiskt land.

- Att det finns möjligheter för att presentera nordisk musik i hela Norden.

\subsection{Scenkonst}

- Att regissörer arbetar på annnan ort än bostadsort - nationellt och internationellt.

- Begrepet mobilitet forstås innen dansen, det å kunne reise og arbeide med dans $i$ andre regioner og land, vise sine forestillinger i andre regioner og land. Dansen er ikke så sterkt avhengig av språket, og det er derfor færre barrierer for dansekunstnere når det gjelder det å reise utenlands for å utøve yrket eller delta på kurs, seminarer, workshops osv.

- Det er åpenhet mellom de forskjellige genre innenfor teater, innenfor offentlig støttede virksomheter og det såkalt frie miljøet. At man bruker hverandres ressurser og spesielle kompetanse.

- Det er selvfølgeligt vigtigt for danske dramatikere at have kontakt/blive spillet i de andre nordiske lande.

- Det som kanske mest påverkar vårt sätt att se på begreppet mobilitet är vårt georafiska läge. Vi ser gärna att scenkonsten bereds möjlighet till mobilitet; att tankar, konstnärer, grupper inom teatern skulle ha möjlighet att arbeta tillsammans. Det behövs fler tvärkonstnärliga och gränsöverskridande projekt som man kan delta i och sätta upp inom Norden.

- Filmarbeidere er i stor grad vår tids nomader. Det betyr at film- og fjernsynsproduksjoner forflytter seg fra location til location, fra landsdel til landsdel og til utlandet. Man kan si at det fordrer en kronisk mobilitet. Dersom man tenker seg mer permanent flytting, når man bruker begrepet, så opplever vi i Norge at mange ønsker å flytt tilbake til sine landsdeler etter år i Oslo eller i utlandet. Forventningene til en ny regional filmpolitikk er stor i den sammenhengen.

- Måttet av turnéverksamheten och gästföreställningar är litet - i synnerhet internationellt. $90 \%$ av aktiva regissörer och dramaturger (och 50\% av skådespelare därtill) jobbar på freelance-basis här i landet. Det är vardagens mobilitet. Den absoluta majoriteten av de 500 nya yrkesteater- och dansföreställningar som produceras i Finland görs av freelancarna.

- Mobilitet inom danskonsten har alltid varit en väsentlig del av dess egenart. En gränsöverskridande konstart behöver enbart ekonomiskt stöd för att kunna upprätthålla sin verksamhet, vara nyskapande och i 
kontinuerlig utveckling. Danskonstnärer har alltid letat efter nya intryck från andra kulturer och idag visas redan en femtedel av dansföreställningarna utomlands. Mobiliteten borde ytterligare stödas; bästa sättet att få till stånd innovationer är att skapa nya samarbetsformer och genom att man kan mötas på ett internationellt plan.

- Möjlighet att vistas utomlands som fristående konstnär och yrkesutövare samt gästspel de Nordiska länderna emellan.

- Möjlighet till gästspel med en viss teaterproduktion både inom instiuionerna och de fria grupperna till annat nordiskt land möjlighet till studier för en kortare tid.

- Muligheten for å arbeide i nye kostellasjoner.

- Det at vi er plassert midt $i$ havet og det at vi er ganske få gjör berepet temmelig fjernt. Men vi ville gjerne at senekunsten hadde mulighet for å være mere mobil, at ideer, kunstnerer, grupper og teatre hadde muligheter til å samarbeide. Det ville være morsomt å se flere produkter som var utarbeidet på tvers av kunstartene og landegrensene og at vi fikk også prosjekt som var utarbeidet og vist frem over hele norden. 


\section{Definitioner av begreppet residens}

Också begreppet residens kan uppfattas på många olika sätt. Därför är det relevant att veta hur den nordiska konstnärsmiljön uppfattar begreppet och hur användningen av begreppet skiljer sig inom olika konstområden. Det internationella residensnätverket Res Artis beskriver och definierar residensverksamhet på följande sätt:

\footnotetext{
"Artists residencies invite artists to live and practice their art for a period of time within the residency organisation, away from their usual environment. A residency program allows an artist to investigate his/her art practice by involvement in another community. It emphasises the importance of meaningful cultural exchange and dialogue with another culture. A wide variety of arts organisations, tertiary institutions and artist-run initiatives host residencies. Currently there are over 600 such programs hosted globally. The interaction between the resident and the host is often an important aspect of a residency program. The form a residency takes will vary as widely as the host. In some artists are involved in the day to day operations of their host giving talks and lectures, or presenting workshops or engaging in formal teaching. Other residencies make no such demands and provide artists with time to investigate their art practice in the context of a new culture. In many cases residencies provide artists with their first extended visit to a host country, often a radical departure from their own culture. A residency can open doors and create opportunities for the artist to build on in future visits."
}

\subsection{Bildkonst}

- Att det finns hus och lägenheter där konstnärer kan jobba i fred, gärna utomlands.

- Att jobba i residens brukar innebära en vistelse som räcker från några månader till ett par år i ett annat land. Tiden används till att få nya tankar och metoder då det gäller ens jobb och till att bygga nätverk för framtida projekt och verksamhetsformer.

- En tildeling af residency skal omfatte logi, værkstedfaciliteter og dieter for hele opholdet. Evt. seminarer, kunstner/kurator talks mm. bør også tibydes ansøgerne uden omkostning. Det er væsentlig at faciliteterne imødekommer behov som studiesamlinger/faglitteratur, computer faciliteter $\mathrm{mm}$.

- Et sted og bo og et sted å arbeide, gjerne adskilt slik at arbeidsprosesser som ikke altid er forenelig med boligformål kan utføres. Innenfor noen arbeidsområder kreves også tilgang på egnet verktøy/utstyr for å kunne arbeide konkret. 
- För arkitekternas vidkommande kunde residens betyda en fast bostads- och arbetsplats i Finland.

- För en bildkonstnär är det mycket viktigt att kunna arbeta utomlands. För många konstnärer är det just arbetsperioden utomlands som har inneburit en vändpunkt med tanke på den egna konstnärliga produktionen. Residens bör emellertid inte endast bestå av en bostad och en ateljé. Det vore bra om residenset också kunde omfatta kontakter till lokala konstorganisationer, gallerier mfl aktörer samt möjlighet att också kunna visa sina verk offentligt.

- Opphold i gjesteatelier er godt egnet for å eksperimentere med flere materialer, sette teorier om i praksis, knytte nye kontakter, kunne bruke større produksjonsutstyr (fabrikker) og dermed akselere den kunstneriske produksjonen.

- Organisationens sekretariat, tilsvarende organisationers sekretariat/indland som udland, oversigt over museer, gallerier, værksteder, centre med studieophold, værksteder med studieophold.

- Svårt här at riktigt förstå vad ni vill veta. Residens för oss eftersom vi jobbar med bilder och visuella uttryck som oftast reproduceras och sprids. Därför är ju språkområdet/mediaindustrin vår yrkesmässiga residens.

- Uppehålla en viss tid borta hemifrån där man har ett arbetsrum med teknisk utrustning. Stärka konstnärernas nätverk.

\subsection{Litteratur}

- Enligt min uppfattning erbjuds konstnären inom ramarna av ett residensprogram arbetsmöjlighet och ett stipendium i ett annat land. Detta sker i samarbete med de andra deltagare i residensprogrammet samt med professionella från den lokala miljön. För närvarande har översättarna möjlighet till denna typ av verksamhet vid de lokala översättarcentren, t.ex. Östersjöns Författar- och Översättarcentrum på Gotland. Översättarna har möjlighet till vistelsestipendier vid olika författar- och översättarcenters, även om det inte specifikt handlar om ett residensprogram. Så vitt jag vet finns det inte några residensprogram inriktade speciellt för översättare.

- Kortere eller lengre arbeids- og studieopphold utenfor hjemlandet, som f. eks. ved Forfatter- og Oversettersenteret i Visby.

- Med betoning på längre vistelser i samband med större litterära projekt - möjlighet att besöka och vistas i de länder de har behov av. Även i form av öppna arbetstipendier som bereder tillfälle till spontana möten och kontakter. 


\subsection{Musik}

- Att det finns möjligheter för nordiska musiker att kunna arbeta i gemensamma projekt.

- De tonsättare som är medlemmar i svenska FST, behöver inte vara svenska medborgare, vara utbildade i Sverige eller ens bo där. Man skall ha en anknytning till det svenska musiklivet. Ur föreningens perspektiv är man därmed resident. Man kan i och för sig vara "resident" i flera länders musikliv.

- I fortsættelse af mobilitet f.eks.: Evne til hurtigt at tilpasse sig nye omgivelser, evne til at skabe socialt og fagligt netværk, evne til åbenhed for forandringer.

- Residens betyder logi och arbetsrum utomlands - alltså arbetsmöjligheter med kontakter till lokala kolleger och musiker. Det är också ofta bra, att komma bort från dagliga rutiner och kunna koncentrera sig i skapande arbete djupare än vad det kanske annars är möjligt $i$ vardagen. Ofta är det också mycket stimulerande att arbeta i en ny omgivning.

\subsection{Scenkonst}

- Et sted dramatikeren kan sitte å skrive eller få utviklet sitt manuskript.

- Film- og fjernsynssektor er i utgangspunktet konservativt. Med det mener jeg at det er krevende å fă til endringer. Vi ser det ift at det er en sterk underrepresentasjon i alle de nordiske landene ift kjønn. Når man ser på nøkkelfunksjonene produsent, regissør og manusforfatter, så går omlag $80 \%$ til menn og $20 \%$ til kvinner. Bildet ift personer med fremmedkulturrell bakgrunn er enda mye mer nedslående. Dette er et område Norsk filmforbund kommer til å bruke mye krefter på i årene framover.

- Finns egentligen inte.

- Möjlighet att bo på förmånligt pris i ett främmande land för att ta avstånd till sina rutiner, förnya uppfattningen av sitt eget konstområde och resonera dess relation med tiden.

- Möjlighet att tillfälligt bosätta sig i ett annat land för förberedning eller verkställande av projekt.

- Möjlighet till längre studier eller arbete i ett annat nordiskt land inom scenkonstens område.

- Motsats till mobilitet, någonting som är bundet $i$ ett fast ställe.

- Muligheten for å bo en periode et annet sted enn hjemme for å forske eller utarbeide nye prosjekter

- Residens betyder for vores medlemmer dels livsvigtig arbejdsro, dels igen kontakt med andre landes kollegaer, producenter osv. 
- Residens forstås innenfor danseområdet, til å være et sted som stilles til disposisjon for danseren eller koreografen eller begge for å arbeide frem f.eks. danseproduksjon og deretter vise produksjonen, der den som tilbyr residensen betaler de fleste utgifter for kunstnerens opphold og arbeid. Residens kan også forstås slik at man tilbys bomuligheter i forbindelse med studier o.l.

- Residens för danskonstnärer innebär ofta en arbetsperiod från en till flere månader. Då arbetar koreografen process- eller worshopsartat, antingen ensam eller tillsammans med dansare för att skapa en föreställning, ett resultat. Vanligtvis förutsätter arrangören ett resultat men arrangören kan också erbjuda utrymme och arbetsfaciliteter utan att kräva något resultat. Till exempel The Place $\mathrm{i}$ London erbjuder möjligheter att under sommarmånaderna arbeta i perioder och de erbjuder en daglig övninssal, teknik för att kunna experimentera etc. Residensernas innehåll är varierande, men det krävs i allmänhet inte bilaterala avtal. Man förväntar sig alltså inte att den som ansökt om residens borde kunna erbjuda samma slags möjligheter för någon annan i sitt hemland. 


\section{Verksamhetsmiljön och arbetssätten i förändring}

Också i Norden är verksamhetsmiljön och arbetssätten i förändring inom alla konstområden. En förståelse av detta förändringstryck kan hjälpa vid planeringen av det nya mobilitets- och residensprogrammet eftersom programmet borde kunna svara på framtida behov.

\subsection{Bildkonst}

- Billedkunstnernes Forbund og en lang række nordiske kunstnerorganisationer har været stærkt kritiske overfor reduktionen af dialog og netværk med kunst og kulturlivet i den nye struktur. De traditionelle forestillinger om geografisk centrum og periferi er under afvikling $i$ en multispaciel tidsalder betinget af globaliseringen.

- Business attityden är på gång att komma in även i den mera artistiskt motiverade delen av vår branch. Många vill börja med eget företag. Nätverk-baserad verksamhet är också i bra kurs.

- Den digitala omvälvningen innebär stora förändringar i arbettsätten och även i distributionen av de färdiga konstverken. Detta ställer även nya krav på upåphovsrättslagstiftningen. Annars har ingenting särskilt nytt hänt, och det bästa är att stödja konstens grundförutsättningar: beställningar osv.

- Den digitala tekniken har förändrat vår möjlighet till visning och distribution av illustrationer/grafisk formgivning. Det har också gjort oss geografiskt oberoende, men beroende av uppkoppling mot internet. Vi har också gått från statisk bild till allt mer rörlig bild. Därför har tex musik och ljud blivit nya områden som blir möjliga att integreras med illustration och grafisk form.

- Flere og flere kunsthåndverkere er i kontakt med utlandet både gjennom videreutdanning, gjesteopphold, utstillinger og ved å ha utenlandske forelesere på høyskolene. Økt tilgjengelighet gjennom Web etc gir større forståelse av det som skjer utenom hjemlandet.

- I framtiden arkitekten arbetar alltmer med digitala informationssystem. Ett sådant arbete är inte bundet till tid och rum.

- Innen mitt speifikke område grafikk, har de siste årene den digetale teknologien fått om-seg-gripende konsekvenser.

- Internationalisering, større markedsføring, produktion af mindre serier - designere i Danmark og producenter i udlandet, afsætning til det udenlandske marked. 
- På Island ökar antalet konstnärer hela tiden och konstnärerna är bättre utbildade än tidigare. Arbetsförhållandena har inte förändrats i takt med samhällsutvecklingen. SÍM arbetar kontinuerligt med att förbättra konstnärernas arbetsförhållanden så att de skulle ha bättre förutsättningar att arbeta med sin konst. Mycket har förändrats under de senaste åren och skillnaderna mellan olika konstarter håller på att minska. Skapande har större relevans i samhället än tidigare. Konsten har större betydelse i samhället än tidigare.

- $\AA$ ena sidan borde den lokala samarbetspartnern erbjuda residenskonstnären tillfällen att träffa konstnärer, gallerister samt arrangera möjlighet för att hålla utställning eller för att på något annat sätt kunna visa sina verk. Men å andra sidan borde konstnärsorganisationernas, de konstnärsledda föreningarnas och konstnärernas direkta kontakter stödas så att det nordiska utställningsutbytet och samarbetet skulle fungera bättre än vad det gör nu.

- Ökade kontakter utanför det egna geografiska området för att hitta en större marknad och få inspiration och vidareutveckling av sitt hantverk.

\subsection{Litteratur}

- Den økende kommersialiseringen av bokbransjen i alle de nordiske landene sammen med det stadig sterkere språklige presset fra engelsk, gir seg blant annet utslag $i$ at flere og flere titler oversettes fra engelsk og amerikansk på bekostning av nabolandslitteraturen og litteratur fra andre deler av verden. Samtidig som vi ser at all oversatt litteratur marginaliseres i forhold til nasjonallitterauren. Kommersialiseringen har også ført til dårligere økomiske betingelser for den enkelte oversetter.

- Framför allt inom översättarområdet blir det svårare att hitta pengar eller förutsättningar för riskprojekt. Att introducera okända författarskap från grannländerna tex. För författare är det lättare att få stipendier för vistelser i andra delar av europa. Man söker sig i större utsträckning längre bort. Resor och logi inom norden är rätt kostsamma och därför svåra att realisera.

- Samhällen och språken förändras snabbare än förut, översättarnas kännedom om länder och kulturer måste hela tiden vara uppdaterad. För att utvecklas i sitt översättaryrke är det på alla sätt fruktbart och av största vikt att arbeta i det landet vars språk man översätter från. Betydelsen av det internationella samarbetet ökar också i den alltmer globaliserade arbetsmiljön som översättarna agerar i. Översättaryrket överskrider gränser och därför är också gränsöverskridande samarbete ytterst viktigt när det gäller översättarnas arbetsvillkor, avtal och upphovsrätt. 


\subsection{Musik}

- Fram till nu har en av de hittills existerande kommittérna - NOMUS framgångsrikt och med en mycket liten organisation administrerat ett väl fungerande utbyte mellan tonkonstnärer, institutioner och utövande musiker i de nordiska länderna. $\mathrm{Nu}$ är den nedlagd enl. beslut i Nordiska Ministerrådet. Vad som kommer därefter vet ingen. Den största nyheten de senaste åren är att nordiska musikinstitutioner börjat samarbeta om beställningsverk av tonsättare och uppförande i flera länder. (Med stöd av t.ex. NOMUS).

- Konkurrencen blir antagligen hårdare, men det blir inte större förändringar i arbetssätten. Det som blir allt viktigare är personliga kontakter och nätverk. Det kan dock hända, att konstmusikens tonsättare måste i fortsättningen vidga sin verksamhet ännu starkare till andra områden inom musikliv (undervisa, vidga repertoire till övriga genren, musikadministration etc.) för att kunna överleva

- Nævnes kan: Der er kommet større bevidsthed om karriereønsker og mål og større bevidsthed om krav til egne evner og egen arbejdsindsats til forfølgelse af ønsker og mål og større bevidsthed om krav til professionalisme og krav til ekstern professionel rådgivning.

- Stærk skift fra mere traditionel noteret musik mod mere eksperimenterende udtryk: lyd fremfor tone, performance fremfor udøvelse.

- Nordiskt samarbeide vil bli mindre og nordisk kultur vil bety mindre i international samenheng.

\subsection{Scenkonst}

- Att det skulle vara lättare och enklare att få stöd för att kunna starta samarbete och projekt för scenkonstnärer i Norden. Så lite pengar som möjligt till byråkrati och så mycket pengar som möjligt till skapande arbete.

- Dansekunst i Norge er i stor utvikling. Norske dansekunstner tar del i den globaliserte verden. Mange tar utdanning i utlandet, eller bor perioder i europeiske byer i Tyskland, Belgia og Nederland. De senere årene har mange norske koreografer og grupper vist sine forestillinger mer i utlandet enn i Norge, på grunn av dårlig utbygd infrastruktur/scener for dans i Norge. Enkelte koreografer har bygd opp kontaktnett i Europa og ellers i verden, slik som Jo Strømgren kompani, Zero Visibility corp med Ina Christel Johannessen, og Ingun Bjørnsgaard Prosjekt. I tillegg har gruppen We, Scavetta og Homan Sharifi, reist mye utenlands. Noen av disse gruppene har også vært del av EU prosjekter med støtte i KULTUR 2000, og Kaleidoskop. Vi ser også en trend $i$ at noen få norske dansekunstnere arbeider sammen med kunstnere fra andre land i Europa, og viser sine 
forestillinger også i Norge. Særlig BIT Teatergarasjen i Bergen har hatt en viktig nettverksbyggende posisjon, og gjennom dette har flere koreografer fătt kontakter $i$ andre land. Vi ser en positiv politisk holdning til dansekunst nå, og har forventniner om at etableringen av det nasjonale Dansens Hus også skal lede til at forestillinger blir sendt på turné i ulike regioner i landet, og at gjestespill fra utlandet får vise forestillinger i Norge. Dette er i startfasen, og en meget positiv utvikling for alle som arbeider med dans i Norge.

- Den stadig mer akslererende globaliseringen vil etter all sannsynlighet også få konsekvenser for vårt kunstnerområde. Foreløpig har det skjedd lite på feltet i Norge og det har vært lite diskutert i bransjen. Men det er naturligvis en diskusjon vi må ta på alvor.

- Det blir større og større konkurranse. Genrene flyter og pengene kommer fra stadig flere hold. Man jobber både i fjernsyn, film og teater, det kan være nødvendig for å kunne ha dette som arbeid med tilstrekkelig inntekt.

- Det mång- eller tvärkonstnärliga breder ut sig inom scenkonsten i allt större omfattning. Dansen, den nya cirkusen, videoprojiserinar mm. används i större utsträckning och scenkonsten för allt mer samman konstnärer med olika bakgrund. Verksamhetsmiljörena har sökt sig allt mer från de institutionaliserade scenerna till, inte bara nya, tillfälliga spellokaler, utan också, genom den tillämpande scenkonsten (så som forumteater, devising och processdrama) till miljöer inom social- och hälsovårdssektorn och skolväsendet. De här förändringarna sker både inom institutionerna, de fria grupperna och enskilda scenkonstnärer.

- En ny skattelagstiftning har gjort att "mobiliteten" har minskat. Regissörerna arbetar allt mindre internationellt och har färre arbeten nationellt. Arbetsförhållandena har förändrats genom ett ökat användande av samproduktioner från Institutionsteatrarnas sida; en form som inte har reglerats i kollektivavtal om ersättningar o dyl. De betyder i praktiken 2 produktioner för samma pris som en, för teatrarna och 1 regiarbete istället för 2 för regissörskollektivet.

- Innenfor scenekunst er det i ferd med å skje store endringer. Skuespillerne er blitt kunstnere på lik linje med billeedkunstnere etc. De må selv skape sitt eget arbeidssted og utvikle sitt eget arbeid. Færre og Færre er ansatt ved et teater. Skuespillerne må selv ta ansvar for sin egen kunsteriske utvikling og sine levekår på en helt annen måte enn for bare ti år siden.

- Om det bara skulle finnas mera arbetsmöjligheter tycker jag att danskonstnärernas arbetsmiljö och arbetsmetoder i och för sig är i ordning. Antagligen är det samma problem i hela Norden: konstnärerna är ivriga och villiga att arbeta och de är redo att ge avkall på sin socioekonomiska status och lön, fysiska faciliteter etc. - om de bara kan arbeta med det yrke som de har valt. Det är fint att man vill 
förstärka mobiliteten inom Norden och ett sätt att öka nationell finansiering är att öka finansieringen just med hjälp av mobilitets- och residensprogram. Det är ganska frustrerande att man stöder finansiering av nordiska stödordningar, när den nationella finansieringen släpar efter - åtminstone när det gäller danskonst.

- Samma problem som inom andra sektorer, snuttjobben ökar, fasta anställningar färre, av Finlands Svenska Skådespelarförbunds ca 130 aktiva medlemmar (+ 50 pens och stud) är över 90 st frilansare!

- Situationen kräver förmågan att anpassa sig snabbt till nya förhållanden, arbetskamrater och arbetssätt. Detta håller en vaken men är även mycket förslitande. Det kan leda till att man blir ytlig, verkställare i stället för konstnär. Många teatermänskor känner sig övergivna. Arbetssätt håller på att ändras för en del av teaterfolk tar själv ansvaret av sin konstnärlig utvecklig. När folk ser att yrskesbranchen inte bjuder på utvecklingsmöjligheter skaffar de själva dem. Antalet av sk. egna produktioner växer kontinuerligt. Man måste satsa mera pengar för denna verksamhet både nationellt och internationellt. 


\section{Behov och nordisk finansiering}

För att kunna planera det nya mobilitets- och residensprogrammet skall man först kunna ha en överblick över vilka behov det just nu finns inom olika konstområden i Norden. Planeringen underlättas också av att man har en uppfattning om vad som nu finansieras nationellt och av att ha en åsikt om var en nordisk insats kan utgöra en skillnad.

\subsection{Bildkonst}

- De nationale programmer faciliterer først og fremmest eksponeringer på internationale kunstinstitutioner og residencies uden for Norden. Hvis programmet skal sikre at der fortsat eksisterer en særlig nordisk optik og udveksling/udvikling i en globaliseret verden, må programmet facilitere netværksdannelser mellem kunstnere, mellem kunstnere og kunstfaglige personer/institutioner, og en del af programmet må rette sig mod at disse netværk inddrager internationale kunstnere, kuratorer, kritikere og institutioner i samarbejder i og udenfor Norden. Som netværksdannende aktiviteter forstås; residency programmer der sikrer kontakt og dialog og evt. samarbejder med kunstnere, kunstinstitutioner, kritikere og kuratorer i residency landet. Længerevarende ophold der muliggør personlige møder med andre nordiske og internationale kunstnere på residency pladsen. Eksponering af allerede producerede værker, udstillinger og projekter af anerkendte kunstnere varetages allerede af de nationale institutioner og behøver ikke yderligere nordisk støtte.

Programmets identitet bør afspejle det moderne Norden som et område med et enestående kulturhistorisk fællesskab i kraft af sin opfattelse af kunst og kultur som værende væsentlige faktorer i en dynamisk demokratisk samfundsudvikling. Et Norden som siden den tidlige industrialisering har været åbent overfor, opsøgende og velinformeret om internationale udviklinger og tendenser. Et Norden som har udviklet et kunststøttesystem hvor de nordiske nationer fastholder den kunstneriske frihed som et velkomment kritisk og dynamisk korrektiv til skiftende paradigmer og politiske strømninger.

Målgrupper och potentielle ansogere: Professionelle skabende og udøvende kunstnere, kunstnere med kuratorpraksis og kuratorer der ansøger i forbindelse med netværksbaserede projekter i samarbejde med kunstne- 
re. Da det nye mobilitetsprogram ikke tilføres væsentlige nye økonomiske midler, bør programmet ikke støtte ansøgere som modtager løn eller honorar andetsteds fra i forbindelse med ansøgte rejse eller projekt. Programmet bør fortsat ikke støtte studerende. Programmet bør fortsat ikke yde økonomisk støtte til nationalt financierede institutioners projekter. Ligeledes må nationale institutioner og kommercielle agenter forventes at dække rejse og transportudgifter i forbindelse med samarbejder med kunstnere.

Særlige støtteområder: De selvstyrende omåder og geografiske randområder bør prioriteres særligt i mobilitetsprogrammet. De særlige vilkår for disse områder er et fælles anliggende som kun kan varetages ansvarligt under en særlig nordisk optik. De baltiske lande er ligeledes et satsningsområder hvor der igennem det hitidige nordiske kultursamarbejde er knyttet gode samarbejdsforbindelser. I lyset af globaliseringen er det væsentligt at fastholde et fokus på disse nærområder. Man kan overveje at ophæve aldersgrænsen på 36, da den i mange tilfælde forekommer absurd pga. de store forskelle i de kunstneriske fags vilkår.

International dimension: Basis for mobilitetsprogrammet bør fortsat være netværksdannelse og samarbejder mellem nordiske kunstnere og kulturproducenter med fokus på udvikling af de aktuelle tendenser. Herunder selvstyreområderne, randomåder og de baltisk lande. Men da samtidskunst i dag I høj grad er internationalt/globalt orienteret, er det nødvendigt, at man på denne basis faciliterer udvekslinger med kunstnere og samarbejdspartnere udenfor Norden, særligt Europa og Mellemøsten hvor Norden historisk set har været engageret, både politisk og i kulturudvekslinger.

Ansöknings og bedömmelsevilkor: Ang. Sleipnir; For billedkunstens område bør man overveje at informationskravene til ansøgninger skærpes. Projekt beskrivelser på 10 linier er ikke tilstrækkeligt til at vurdere en ansøgning. De ansøgere der bruger muligheden for at vedhæfte bilag, letter behandlingen af ansøgningerne meget og nu hvor ansøgningerne behandles elektronisk vil det desuden være oplagt at bede om begrænset billeddokumentation fra kunstnerens arbejde. Når man vurderer nordiske ansøgninger kan én person ikke have referencer nok til at vurdere samarbejdspartnere og cv referencer i hele det nordiske område. Det betyder at en samvittighedsfuld behandling af ansøgninger kræver ekstra reseach på internettet. Dette burde ikke være nødvendigt.

Angående residencies; Uden at kende de nuværende kriterier, skal det siges at det samarbejdsrettede, opsøgende eller netværksdannende aspekt må prioriteres, hvis den nordiske kulturstøtte skal sikre en kvalitativ udvikling af kultursamarbejdet. Selve financieringen af det konkrete residencyprogram kan som nu være sammensat af nordisk kulturstøtte og lokale financieringspartnere. Ansøgere der bliver tildelt residencies bør også sikres støtte til rejseudgifter til og fra pladsen. Dette sker nu igennem Sleipnir. I Sleipnir programmet lægges nu vægt på at de ovenstående 
krav til residency pladsen opfyldes. Rejselegater til andre projekter bør også fortsat kunne opnåes.

Der opstår i disse år en lang række virkelig kvalificerede kunstprojekter i Norden og de baltiske lande, med vidt forskellige samarbejdspartnere. Mange af disse projekter når ud til en stor offentlighed og skaber en fortsat basis for samarbejder på tværs af lande, institutioner og kunstnernetværk. I denne type projekter får man med et beskedent økonomisk tilskud støttet en virkelig fremadrettet professionel udvikling med meget lave administrative omkostninger.

Et nordisk kultursamarbejde må basere sig på fagpersoner der både repræsenterer de forskellige kunstneriske fag og de forskellige lande og selvstyreområder. Dette besværliggør kommunikation og møder. Det kræver et virkelig velfungerende og kunstfagligt professionelt sekretariat som skal have den fornødne fagkundskab til at monitere og vurdere løbende aktiviteter på de enkelte fagområder. Behandlingen af ansøgningerne er det der afgør programmets professionalisme og den mest hensigtmæssige anvendelse af midlerne. På langt sigt er det disse beslutninger, der indenfor rammerne, danner programmets profil. Derfor er det afgørende at de fagpersoner der træffer afgørelserne på de forskellige fagområder har en løbende diskkussion om kriterier og udviklinger på feltet.

I den nuværende struktur refererer de fagkyndige til de nordiske kunstinstitutioner og råd. Dette er en stor støtte for udvekslingen af den nødvendige information, for at kunne vurdere fagområderne $i$ hele deres nordiske udstrækning. I den nye struktur bortfalder denne reference. Hvis ikke dette skal resultere $i$ at de enkelte fagkyndige opererer $i$ et tomrum må de fagkyndinge kunne mødes fysisk flere gange om året og iøvrigt behandle ansøgninger løbende.

Kunstneriske og fagspecifikke beslutninger: Armslængdeprincippet skal opretholdes. Fagkyndige skal være udøvende og skabende professionelle kunstnere og kunstfaglige personer som udpeges nationalt af de respektive organisationer og instanser som normalt udpeger i de enkelte lande. Ang. De faglige kompetancer må man sørge for en bedre dækning af fagområderne end Sleipnir komiteen på nuværende tidspunkt har. Design og arkitektur området behandles nu under billedkunst. Det er ikke acceptabelt. Man kunne forestille sig lign. blinde vinkler i felterne mellem rytmisk/klassisk musik, litteratur/lyrik, dokumentar/spillefilm og moderne/klassisk dans. På billedkunsområdet er det desuden utopisk at forestille sig at én billedkunstner har indsigt $\mathrm{i}$ alle medier og genrer generelt.

Honorar; Nu hvor man indfører en ny struktur kan man ikke længere forlange at kunstfaglige sagkyndige skal arbejde uden passende honorar. Som eksempel kan nævnes at der i Sleipnir komiteen behandles 20-30 billedkunst/design/arkitektur ansøgninger om måneden. Dette arbejde honoreres ikke, udover godtgørelse for afholdte møder. För att garantere 
dialog og netværk med kunst og kulturlivet, der bør oprettes en permanent kunstfaglig instans, der repræsenterer de respektive kunstfaglige områder via repræsentanter for skabende kunstnere, udøvende kunstnere, kunstinstitutioner $\mathrm{mm}$. Samarbejdsaftaler, netværk og eller sociale relationer som programmet kunne omfatte: Her er der utallige muligheder.

Det afgørende er at samarbejdet skal forankres i en nordisk optik. Man kan ikke uddelegere langsigtede programmer til nationale institutioner, hvis man skal fastholde en nordisk optik. Hvorimod enhver type institution, kunstfaglig organisation eller gruppe kan være potentielle samarbejdspartnere til afgrænsede projekter.

Det er vigtigt at forstå den store økonomiske faktor der ligger i netværkstanken. Det at aktører i og udenfor Norden har mulighed for at henvende sig til en veldefineret og kendt nordisk samarbejdspartner på det enkelte fagområder, betyder at man kan gennemføre store satsninger med medfinaciering $i$ en helt anden størrelses orden end hvis samarbejdspartneren er en anonym administrativ instans. De personlige netværk mellem kunstnere, bestemte institutioner og aktører kan ikke undervurderes.

Der bør oprettes en permanent kunstfaglig instans, der repræsenterer de respektive kunstfaglige områder via repræsentanter for skabende kunstnere, udøvende kunstnere, kunstinstitutioner $\mathrm{mm}$. De enkelte residencies skal udvikles som differentierede programmer, hvilket kræver kunstfagligt personale på stedet.

Forhøj budgettet - jo mindre budget en institution har jo højere en procentdel af budgettet vil automatisk gå til administration. Om en årlig evaluering foretages $\mathrm{i}$ en permanent kunstfaglig instans, vore det overskueligt for både brugere og politikere.

De nordiske hovedsprog som er beslægtede; norsk, svensk og dansk skal kunne anvendes. Engelsk kan anvendes i tilfælde hvor norsk, svensk og dansk ikke forstås eller beherskes. Dette har fungeret udmærket i det hidtidige nordiske samarbejde.

- Den gamla strukturen för nordiskt kultursstöd var inte dålig ur kulturens egen synpunkt. Det första målet inom kultur är att stöda det substantiella. Mobilitets- och residensmöjligheter kan vara ett extra bonus, men inte på bekostnad av det väsentliga.

- Det finns ett stort behov av mobilitets- och residensprogram inom bildkonst. En konstnär arbetar ofta ensam för att kunna visa sina verk utomlands och projekten kan inte förverkligas utan finansiering. Också galleriernas och föreningarnas resurser är små. Det är ytterst viktigt att stöda utställningsutbyte i Norden och i Baltikum och att stöda residensverksamhet.

- Det finns ett stort behov av rese- och residensstipendier som gör det möjligt för isländska konstnärer att vistas i gästbostäder i andra nordiska länder. Nordiskt stöd är viktigt för isländska konstnärer, stöd för att hålla utställningar och för att delta i samarbetsprojekt tillsammans med andra nordiska konstnärer. 
- En nordisk reisestøtteprogram ville betyr meget for norske kunsthåndverkere. Det er mye gjensidig utstillingsaktivitet og reisestøtte ville kunne ganrantere at flere kunstnere kan delta på nordiske utstillinger. Også gjesteopphold er svært viktig for den kunstnereiske utviklingen, særlig ved større produksjonsenheter og hvis man er interessert i teknikker/arbeidsmetoder som ikke praktiseres i en eget land.

- Ett nordiskt program skulle vara ett utmärkt tillskott till de möjligheter som nu finns för att arbeta utomlands.

- I det omfang vi har ressourcer til det, trækker vi på samarbejde med vores fælles nordiske organisationer. Men vi ville meget gerne kunne gøre mere.

- Jeg har ikke den fulle oversikten når det gjelder dagens tilbud. Selvsagt vil en nordisk innsats gjøre en forskjell når det gjelder å etablere en plattform for konkrete møteplasser mellom kunstnere.

- Många designare vill gärna jobba perioder utomlands. Kostnaderna brukar vara en problem, som gör det omöjligt. Genom effektivare finansiering kan man finna möjligheter att aktivera mobilitet inom branchen. Annars så finns det redan många intressanta internationella program som man kan ta del i.

- Vi har nära samarbete med de övriga nordiska illustrationsorgansiationerna. Men koppling är stark till förlag/media/språkområde. Därför finns det generellt ett stort behov av ökat utbyte mellan de nordiska ländernas yrkesutövare.

\subsection{Litteratur}

- Fellesnordiske oversetterseminarer vil ha betydning for utbredelsen av kjennskap til og utbredelse av nabolandenes litteratur. Særlig gjelder dette for de språkområdene som skiller seg mest fra de øvrige nordiske, så som finsk, færøysk, grønnlands, islandsk og samisk. Og naturligvis de baltiske språkene. Fellesnordiske fagpolitiske oversetterseminarer vil også ha betydning for hele det nordiske fellesskapet av oversettere. Begge disse tiltakene har tidligere vært finansiert gjennom Nordbok

- Framför allt fasta strukturer för et kulturellt utbyte liknande IASPIS. Det internationella gästhemmet i författarnas hus i Stockholm skulle t.ex må bra av en stark huvudman och större lokaler. Lättare ansökningsrutiner. Och mycket effektivt sätt att använda pengarna tror jag skulle vara att ge en andel direkt till de olika organisationerna att användas i befintliga strukturer.

- I översättarbranschen har det nordiska samarbetet enligt tradition varit starkt liksom stöd till detta samarbete. Det ekonomiska stödet har haft en stor betydelse för framgången för olika projekt. Utan stöd 
skulle översättarna med låg inkomst inte haft möjlighet att delta eller genomföra dessa projekt. Att översätta litteratur från ett nordiskt språk till ett annat är kulturutbyte när det är som bäst. Det lönar sig att stödja detta utbyte när de stora språken pressar på. Jag hoppas samarbetet fortsätter även i framtiden på samma sätt som nu. Resestipendierna för översättare liksom seminarie- och översättningsstödet understödjer skapandet av en högkvalitativ översättningslitteratur. Utan dessa stöd har inte översättarna ekonomiska resurser att arbeta $\mathrm{i}$ ett annat land eller delta $\mathrm{i}$ olika projekt.

\subsection{Musik}

- Der er absolut behov i forbindelse med mere projektorienterede kunstproduktioner hvor skabelsesprocessen involverer en højere grad af samarbejde end den traditionelle dikotymi: komponist $<>$ udøver(e).

- Det blir allt viktigare. Programmen gör det möjligt för en tonsättare att kunna skapa kontakter och bygga nätverk. NOMUS-stöd har haft en enormt stor betydelse för både Nordiska Musikdagar och UNMfestivaler och varit alldeles grundläggande för mycket omfattande kontakter mellan nordiska tonsättare och musiker. Sleipnir har varit säkert bra för unga konstnärer, men för etablerade konstnärer kunde residensprogram också vara nyttiga och användbara.

- Det er vort indtryk, at der ikke hidtil har været en væsentlig nordisk indsats på vore områder. Inden for musikken har det hovedsageligt drejet sig om den klassiske musik, og inden for scenekunsten har det hovedsageligt drejet sig om det dramatiske teater i mere klassisk forstand. Denne indsats skal naturligvis fortsættes. En nordisk indsats på vore områder vil klart gøre en forskel i form af ny fokus på også disse genrer. Vi tænker på f.eks. ny-cirkus området og den nyskabende rytmiske musik. Disse områder vil kunne have stor gavn af en nordisk indsats, som vil kunne være mere med til at skabe ny energi og inspiration.

- Det finns ett stort behov av rese- och arbetsmöjligheter för nordiska musiker. Ett sådant samarbete förstärker nordisk musik såväl inom Norden som internationellt.

- Vi som arbetat med internationella samarbeten inom musikområdet har märkt att: 1. många av de nordiska nationella konst- och kulturstödssystemen är mycket just "nationalistiska" till sin karaktär och medger inte att man söker uppförare eller upphovsmän utanför den egna nationens gränser. Därför finns ett behov både av tvärnationella verkbeställningsmöjligheter och av t.ex. turnéstöd för ensembler och institutioner inom Norden. 2. Trots att de fem nordiska nationerna har valt anmärkningsvärt olika strategier när det gäller förhållandet till EU, så omfattar EU:s olika stödprogram i och för sig de icke-anslutna 
Norge och Island, men att man, i det fall man söker EU-medel för genomförande an explicit Nordiska projekt hänvisas just till de nordiska medel ministerrådet förfogar över. Det finns m a o ett enormt behov av att behålla både omfattning och nivå på finansieringen för att överhuvudtaget vidmakthålla ett nordisk samarbete på musik-, men även på hela kulturområdet. Andra källor är nämligen svåra att finna.

\subsection{Scenkonst}

- Behovet av samarbete är stort, inte minst för ett fjärran och litet land som Island. Vi vil så gjerne ha muligheten til å arbeide med flere senekunstnere en vi kan i vårt lille samfunn.

- Det borde finnas mera möjligheter för alla konstarter, finansieringen borde ökas och samrbetet mellan nordiska festivaler borde stödas. Med lättare strukturer kunde man skapa ett mera flexibelt nordiskt samarbete och på det här sättet framhäva det som är enastående i den nordiska kulturen.

- Det er et stort behov for kunstnerisk utveksling og et slikt nordisk program vil gjøre en stor forskjell fra dagens situasjon.

- Eftersom vi svenskspråkiga skådespelare i Finland i princip har en möjlighet att klara oss på vårt modersmål förutom i Finland och Sverige även i Danmark och Norge skulle det vara fint med ett konkretare kontaktnät för skådespelare som kunde möjliggöra skådisarbetet i ett annat Nordiskt land, en sorts Nordisk marknadsförare av skådespelare.

- En nordisk innsats kan være med på å stimulere til større kvalitet hos den enkelte kunstner. Det vil også styrke båndene mellom land, og kunstneriske uttrykk. Dramatikeren har et dilemma fordi hun/han skriver på norsk, det kan imidlertid inspirere den norske språket, ikke minst innholdssiden å være i program med nordiske kolleger.

- Genom att öka "mobiliteten" inom Norden.

- Jeg tror at innen filmområdet, så har vi mye å hente gjennom tettere og mer organisert samarbeid. Vi trenger friske tanker, fra folk som kan se oss fra utsiden. Og vi trenger å se mer av hva som skjer innen feltet vårt i de andre nordiske land. Tettere og bedre samarbeid kan etter min mening bare føre godt med seg.

- Jeg vurderer, at der er et stort behov netop for den internordiske støtte (som modvægt til den europæiske/amerikanske påvirkning).

- Mulighet for å skape samarbeidsprosjekt og forske i de andre nordiske lands scenekunst er viktig. Nordiske kurs er verdifulle fordi de bringer oss sammmen om et faglig emne.

- Utbyte av erfarenheter, projekt och kunnande är av största vikt. Inte minst för/av oss i Finland som ligger med nära och naturliga 
kontakter till Ryssland och Baltien. Ur ett språkligt perspektiv är det nordiska samarbetet inom scenkonst också av största vikt. Scenkonsten opererar med språket; dels behöver de finskspråkiga bli påminda om det skandinaviska, dels behöver den finlandssvenska minoriteten ha aktiva nordiska kontakter. Via en samnordisk insats, som överskrider det administrativa planet till det praktiska, finns det möjligheter att göra skillnad med väsentlig betydelse.

- Ömsesidiga nordiska gästspel som har varit en gång mycket viktiga bör financieras. Till exempel gästspelverksamhet mellan Finland och Island har fört med sig en fortvarnde livlig växelverkan mellan isländska och finska teatermänskor. Utan att tala om växelverkan mellan Sverige och Finland vars aktivitet tyvärr inte kan jämföras i dag med situationen 15-20 år sedan då vi var i alla avseenden blodbröder.

\subsection{Självstyrande områden}

I de samtal jag fört har det framkommit att det på Färöarna och Grönland är residensbehov inom bildkonst, litteratur och musik som är de största. På Åland finns det största residensbehovet inom bildkonst, film och musik. Från självstyrande områdena vill man helst söka sig till residenser som är belägna i huvudstäder eller andra stora städer. På de självstyrande områdena är den professionella miljön begränsad, och därför har konstnärerna behov av att dela erfarenheter, skapa nätverk och arbeta tillsammans med professionella från andra orter.

Inom bildkonst är det speciellt målare och grafiker som är i behov av residenser där de också har möjlighet att ställa ut sina verk och att presentera sig för publik. Däremot finns det inte någon stor efterfrågan på residens i Dalsåsen eftersom det på de självstyrande områdena finns få skulptörer och konstnärer som använder sig av trä som sitt material. Författarna däremot har mest behov av att få resestöd för deltagande i litteraturfestivaler, litteraturmöten etc. För musikens och filmens del föreligger det behov för produktionsbaserad residensverksamhet.

Konstnärer från de självstyrande områdena har nationellt begränsade möjligheter att få resestöd eftersom också alla frivilliga organisationer, körer etc. tävlar om samma medel. Situationen försvåras också av att resestödet vanligtvis täcker enbart en del av resekostnaderna, till exempel 2700 DKK för en resa som kostar 15000 DKK. 


\section{Fungerande nätverk}

I planeringen av det nya mobilitets- och residensprogrammet är det viktigt att veta vilka slags nätverk det i dag överhuvudtaget existerar inom det nordiska kultursamarbetet. Men framför allt är det viktigt att fă en bild av vilka slags nätverk som fungerar bra inom det nordiska kultursamarbetet i dag.

\subsection{Bildkonst}

- Forum Artis medlemsföreningar har fungerande nätverk med sina nordiska motsvarigheter.

- I Danmark har erfaringerne fra CDBs arbejde vist at netværksfremmende satsninger skaber en effektiv synergi effekt for kunstnerne, kuratorer, kritikere, institutioner og kunstmarkedet, som er langt mere udviklende og økonomisk end store nationale satsninger. Man når bedst ud til de rette målgrupper og potentielle ansøgere genom de respektive fagorganisationer i hvert land, deres fagblade og faglige internetsider der er mest søgt. Desuden nyhedsmails over e-flux. I Danmark anbefales www.kopenhagen.dk og Billedkunstnernes Forbunds blad og hjemmeside. Institutioner som kan nationalt informere om programmet i Danmark: Kunststyrelsen, Billedkunstnernes Forbund og Unge Kunstnere og Kunstformidlere.

- Klys, Dansk Kunstnerråd osv, dvs. paraply- och samarbetsorganisationsnivån har fungerande nätverk.

- Nifca fungerar bra, det är viktigt att man inte förlorar de samarbetsnätverk som har uppstått under Nifcas tid. Samarbetsnätverket BIN (nordiska bildkonstorganisationer) fungerar bra. Man håller ett möte per år, men BIN kunde utvidga sitt arbetsfält ytterligare. På de nuvarande mötena informerar medlemsorganisationerna varandra om aktuell konstpolitik i sina respektive hemländer.

- Nifca, Dalsåsen, Sleipner er nettverk som jeg kjenner til konkrete resultater fra.

- Nordisk hantverksforum - den har också haft utbyte via vestnorden art and craft på Island.

- Nordisk Visuell Kommunikation (fd Nordiska tecknare) ett nätverk mellan de nordisk organisationerna. Inom upphovsrättsfrågorna existerar idag ett samarbete mellan de nordiska bildupphovsmannaorganisationerna.

- Nordiska arkitektföreningar har ett tätt samarbete. 
- Representanterna från de nordiska länderna har fått bra kontakt med varandra genom Beda. Om man inte räknar in personliga kontakter, så finns det inte särskilt bra nätverk inom branscherna för design och konsthantverk.

\subsection{Litteratur}

- Først og fremst Nordisk Forfatter- og Oversetterråd (NFOR). Dessuten det nære fagpolitiske samarbeidet som med støtte gjennom Nordbok har utviklet seg de senere årene mellom de skjønnlitterære oversetterorganisasjonene i Norden.

- Nordbok, Biskops-Arnö.

- Översättarseminarierna som Nordbok stött har varit givande och även främjat nordisk litteratur. Vart och ett av de nordiska länderna har arrangerat seminariet för översättare som specialiserat sig i värdlandets språk och litteratur. På seminarierna diskuterades förutom översättningsproblemen bland annat de nya trenderna i värdlandets litteratur. Med stöd från Nordbok har det även arrangerats så kallade fackpolitiska seminarier där översättarna bland annat behandlat branschens avtals- och upphovsrättsfrågor.

\subsection{Musik}

- De væsentligste netværk inden for vore områder eksisterer uden for de officielle kanaler - det vil sige inden for de enkelte brancheområder, uddannelsesområder eller privat. Nævnes skal dog ROSA, som udfører et flot arbejde og bl.a. arrangerer den årlige SPOT festival. Dette arbejde er med til at skabe ovennævnte netværk - også på nordisk plan.

- Nordisk Komponist Råd (NKR) och dess festival Nordiska musikdagar, Ung Nordisk Musik (UNM) och dess UNM-festival samt Nordiska MIC-organisationer.

- Nordisk Komponistråd, Nordiske Musikdage, Ung Nordisk Musikfest.

- NRK - Nordisk Komponistråd, är en sammanslutning av organisationer på tonkonstnärsområdet, som nyligen förstärk och utökat sin verksamhet dels med finansiering från NOMUS dels också, och i huvudsak, med bidrag från medlemsorganisationerna. 


\subsection{Scenkonst}

- Finlands Regissörförbund och Sveriges Regissörer: mycket bra, Nordisk Råd för Sceninstruktörer: ganska bra. Vårt livligaste nätverk är med Estland: med Eesti Teatriliit (Estlands Teaterförbund) och Eesti Lavastajate Liit (Estlands Regissörförbund). Det skulle vara mycket viktigt att nordiska kulturpengar skulle nå dem också.

- For dramatikeres vedkommende, ingen.

- Jag har för mig att NordScen har fungerat relativt bra. Har inte själv deltagit i något projekt. Är själv aktiv inom nordiska sammanhang via förenings- och förbundssammanhang som Nordiska Skådespelarrådet och Nordiks Teaterunion. Som kanaler för utbyte av information och erfarenheter fungerar dessa väldigt bra.

- Min personliga erfarenhet begränsar sig till NordScens och Nordisk Skuespillerådets verksamhet. Enligt min mening representerar NSR:s möten ett fungerande nordiskt samarbete. Verksamhetsmodellen bygger på öppenhet och frivillighet. Det här främjar också informationsutbytet mellan länderna och sprider kunskap om aktuell kulturpolitik i Norden.

- Nordisk Skuespillerråd fungerer suverent med møte i et av de nordiske land hver vår og hver høst.

- Nordiska Skådespelarrådet, fyller 70 år! (äldst bland de Nordiska samarbetsorganen?)

- Nordiske teaterdage. Nordisk dramatikerunion.

- Norske Dansekunstnere er medlem i Nordisk Skuespillerråd et viktig forum for kunstnerorganisasjonene som representerer dansere, koreografer, skuespiller og sangere m.fl. Vi kjenner til få nordiske nettverk som er spesielle for dansekunst. NordScen har spilt en viss rolle, og det nye Nettverket av nordiske informasjonskontorer for dans kan bli en interessant tilvekst $i$ infrastrukturen rundt kunstnerne.

- NSiR - Regissörernas samarbetsorgan inom Norden.

- Våre organisasjoner jobber sammen i FERA og MEI. Norsk filmforbund har nå fått aksept fra Den Norske filmfestival, som har tatt mål av seg til å bli et Nordisk forum, for å lage et bransjetreff for organisasjonene på film- og fjernsynsfeltet. Ellers ser vi med spenning fram til et nærmere samarbeid mellom Filmpool Nord og det Nord Norske miljøet og likeledes mellom andre av våre nordiske miljøer ift produksjon og prosjektutvikling. 


\section{Påståenden om ett nytt resestipendieprogram}

Värdera följande påståenden

Det nya mobilitetsprogrammet bör öppnas för sk förmedlare av konst, som kuratorer, producenter, kritiker, kulturredaktörer och översättare. (Medelvärde: 3,444; Sammanlagt: 27)

Det nya mobilitetsprogrammet bör öppnas för sk förmedlare av konst, men i ansökningsvillkoren bör man betona konstnärer. (Medelvärde: 4,929; Sammanlagt: 28)

Det nya mobilitetsprogrammet bör inte ha några åldersgränser. (Medelvärde: 5,741; Sammanlagt: 27)

Det nya mobilitetsprogrammet bör inte ha några åldersgränser, men man bör i ansökningsvillkoren betona unga sökande. (Medelvärde: 3,321; Sammanlagt: 28)

Stipendierna inom det nya mobilitetsprogrammet bör beviljas enbart på konstnärliga grunder. (Medelvärde: 5,37; Sammanlagt: 27)

Det nya mobilitetsprogrammet bör omfatta kvoter för varje land. (Medelvärde: 4,63; Sammanlagt: 27)

Det nya mobilitetsprogrammet bör omfatta kvoter för sökande från de självstyrande områdena och fö samerna. (Medelvärde: 4,75; Sammanlagt: 28)

Det nya mobilitetsprogrammets stipendier bör inte täcka alla kostnader, utan den sökande bör söka en del av finansieringen från andra instanser. (Medelvärde: 2,929; Sammanlagt: 28)

Det nya mobilitetsprogrammet bör bevilja större summor per sökande än vad som nu är fallet, också om detta skulle betyda att färre sökande beviljas stipendier. (Medelvärde: 4,393; Sammanlagt: 28)

Det nya mobilitetsprogrammet bör utvecklas till ett nordikst-baltiskt program, inom vilket såväl nordiska som baltiska sökande har samma förutsättningar. (Medelvärde: 3,852; Sammanlagt: 27)

Det nya mobilitetsprogrammet bör ha en särskild kvot för baltiska sökande. (Medelvärde: 3,704;

Sammanlagt: 27)

De baltiska länderna bör också i fortsättningen ha ett skilt program (nuvarande Sleipnir-Baltia). (Medelvärde: 4,464; Sammanlagt: 28 )

Det nya mobilitetsprogrammet bör öppnas också för internationella sökande. (Medelvärde: 2,37; Sammanlagt: 27)

Medelvärde: 4,146; Sammanlagt: 357

\begin{tabular}{|c|c|c|c|c|c|}
\hline $\begin{array}{c}\text { Helt av } \\
\text { annan } \\
\text { åsikt } \\
\text { (Värde: 1) }\end{array}$ & $\begin{array}{l}\text { Nästan av } \\
\text { annan } \\
\text { åsikt } \\
\text { (Värde: 2) }\end{array}$ & $\begin{array}{c}\text { Lite av } \\
\text { annan } \\
\text { åsikt } \\
\text { (Värde: } 3 \text { ) }\end{array}$ & $\begin{array}{l}\text { Lite av } \\
\text { samma } \\
\text { åsikt } \\
\text { (Värde: 4) }\end{array}$ & $\begin{array}{l}\text { Nästan av } \\
\text { samma } \\
\text { åsikt } \\
\text { (Värde: 5) }\end{array}$ & $\begin{array}{c}\text { Helt av } \\
\text { samma } \\
\text { åsikt } \\
\text { (Värde: 6) }\end{array}$ \\
\hline $3,7 \%$ & $29,6 \%$ & $18,5 \%$ & $29,6 \%$ & $3,7 \%$ & $14,8 \%$ \\
\hline 1 & 8 & 5 & 8 & 1 & 4 \\
\hline $3,6 \%$ & $10,7 \%$ & $3,6 \%$ & $14,3 \%$ & $7,1 \%$ & $60,7 \%$ \\
\hline 1 & 3 & 1 & 4 & 2 & 17 \\
\hline $0 \%$ & $3,7 \%$ & $0 \%$ & $0 \%$ & $11,1 \%$ & $85,2 \%$ \\
\hline 0 & 1 & 0 & 0 & 3 & 23 \\
\hline $25 \%$ & $7,1 \%$ & $21,4 \%$ & $14,3 \%$ & $21,4 \%$ & $10,7 \%$ \\
\hline 7 & 2 & 6 & 4 & 6 & 3 \\
\hline $0 \%$ & $3,7 \%$ & $3,7 \%$ & $7,4 \%$ & $22,2 \%$ & $63 \%$ \\
\hline 0 & 1 & 1 & 2 & 6 & 17 \\
\hline $3,7 \%$ & $3,7 \%$ & $14,8 \%$ & $22,2 \%$ & $14,8 \%$ & $40,7 \%$ \\
\hline 1 & 1 & 4 & 6 & 4 & 11 \\
\hline $10,7 \%$ & $3,6 \%$ & $0 \%$ & $17,9 \%$ & $21,4 \%$ & $46,4 \%$ \\
\hline 3 & 1 & 0 & 5 & 6 & 13 \\
\hline $28,6 \%$ & $17,9 \%$ & $17,9 \%$ & $14,3 \%$ & $10,7 \%$ & $10,7 \%$ \\
\hline 8 & 5 & 5 & 4 & 3 & 3 \\
\hline $3,6 \%$ & $10,7 \%$ & $10,7 \%$ & $21,4 \%$ & $25 \%$ & $28,6 \%$ \\
\hline 1 & 3 & 3 & 6 & 7 & 8 \\
\hline $18,5 \%$ & $7,4 \%$ & $7,4 \%$ & $29,6 \%$ & $11,1 \%$ & $25,9 \%$ \\
\hline 5 & 2 & 2 & 8 & 3 & 7 \\
\hline $18,5 \%$ & $11,1 \%$ & $18,5 \%$ & $7,4 \%$ & $22,2 \%$ & $22,2 \%$ \\
\hline 5 & 3 & 5 & 2 & 6 & 6 \\
\hline $17,9 \%$ & $3,6 \%$ & $0 \%$ & $10,7 \%$ & $28,6 \%$ & $39,3 \%$ \\
\hline 5 & 1 & 0 & 3 & 8 & 11 \\
\hline $44,4 \%$ & $25,9 \%$ & $3,7 \%$ & $7,4 \%$ & $11,1 \%$ & $7,4 \%$ \\
\hline 12 & 7 & 1 & 2 & 3 & 2 \\
\hline $13,7 \%$ & $10,6 \%$ & $9,2 \%$ & $15,1 \%$ & $16,2 \%$ & $35 \%$ \\
\hline 49 & 38 & 33 & 54 & 58 & 125 \\
\hline
\end{tabular}


Del IV: " De fyra modulernas modell" - Förslag till ett nytt mobilitets- och residensprogram 


\section{Förslagets utgångspunkter}

Många av de nordiska kulturinstitutionerna och -kommittéerna har haft en stark position på det nordiska konstfältet. Det kan nästan ge intrycket av att ju bättre de nordiska institutionerna har lyckats i sin verksamhet, desto mer har de nationella aktörerna dragit sig ur det nordiska samarbetet. De nationella aktörerna har koncentrerat sig på nationella och internationella uppdrag utan att ha en nordiskt uppdrag.

Denna konstellation ändras då ett stort antal av de nordiska aktörerna avvecklas. Samarbetsstrukturer försvinner och det finns inte ekonomiska förutsättningar att skapa en ny liknande permanent struktur. Därför är det nödvändigt att inleda samarbete med existerande strukturer. Visionen är att man skall kunna skapa sammanhang och förena resurser i Norden.

Det finns stor efterfrågan på mobilitets- och residensverksamhet inom alla konstarter i Norden. Konstarterna har behov av mobilitet, men behoven är olika inom de olika konstarterna. Programmet skall kunna svara mot befintliga behov och efterfrågan. Det är stora variationer i efterfrågan, beroende på hur man i de nationella systemen lyckats svara på behoven.

Det nya mobilitets- och residensprogrammet skall kunna erbjuda möjligheter för ett bättre samarbete mellan redan befintliga residensprogram och skapa möjligheter för ny verksamhet. Programmet skall på ett modernt, smidigt och effektivt sätt kunna reagera på konstarternas skiftande behov och utveckling. Det är inte bara konstnärerna som har behov av mobilitet. Också andra nivåer i konst- och kulturfältet har behov av mobilitet och därför betraktar det nya programmet konstfältet i ett brett perspektiv. Målsättningen är att på ett nytt sätt skapa kontakter och gemensamma intressen och förstärka utvecklingen nationellt.

Detta är inte möjligt att genomföra med endast ett stort och alltomfattande program. I stället ska programmet byggas upp av moduler, som kan startas upp och avslutas i olika rytmer. En modul kan vara i tre år, en annan i fem år, helt beroende på efterfrågan. När en modul avslutas kan den utvecklas på basen av de erfarenheter man har fått. Modulerna kan avlösa varandra och det innebär att man inte behöver avveckla hela programmet när en modul avslutas eller förnyas.

En modell som är uppbyggd på efterfrågan och moduler förutsätter att organisationens arbetssätt måste vara processinriktat. En kontinuerlig utveckling av modulerna förutsätter kontakt och dialog med hela konstfältet i Norden. 


\section{Beskrivning av modulerna}

\subsection{Modul 1: Stöd till nätverk}

Modulen stöder nätverksbildning inom det nordiska konstfältet. Via modulen kan man inte skapa nya permanenta strukturer, men däremot förutsättningar för att existerande aktörer skall kunna samarbeta, utveckla partnerskap och lära av varandra. Genom nätverksbildning som bygger på samverkan och personliga kontakter förstärks det nordiska konstfältet möjligheter att utvecklas och dess förutsättningar att t.ex. konkurrera om internationell finansiering till samnordiska projekt.

Inom denna modul kan nordiska närverk två gånger årligen söka om stöd till ett långsiktigt och organiserat nätverksarbete. Stödet kan beviljas till redan existerande organisationers, gruppers och föreningarnas nätverk och deras gemensamma arbete. Som exempel på möjliga nätverk som kunde söka stöd i denna modul kan nämnas centralerna för internationellt bildkonstutbyte, litterära festivaler, gästspelscener och -teatrar, informationscentralerna för musik etc.

Stödet inom denna modul beviljas som ett engångsstöd för tre års nätverksarbete. Nätverket kan efter de tre första åren ansöka om stöd till ännu två år. Vid sidan om stödet kan nätverket också erbjudas en gemensam resurs för informationsarbete. I de fall där det är möjligt skall man koppla olika nätverk till varandra.

Modulen erbjuder också möjligheter till helt att helt nya, kortvariga nordiska nätverk uppstår. Ett nytt nätverk kan beviljas stöd till ett års verksamhet. Efter det första året kan nätverket ansöka om stöd för ännu ett års fortsatt verksamhet. Ett välfungerande nätverk kan efter detta övergå till att söka om stöd till långvarigt nätverksarbete. De kortvariga nätverken skall kontinuerligt kunna ansöka om stöd (Expression for Interest). Det är viktigt att få in en så stor och dynamisk mängd ansökningar som möjligt att den ger indikationer om vad som är på gång i det nordiska konstfältet.

Ansökningarna behandlas varje månad. Ansökningen kan antingen a) godkännas, b) avslås eller c) man går i dialog med ansökaren och ger feed back om hur ansökningen kunde utvecklas med tanke på kommande ansökningsomgångar. Ansökaren kunde också få förslag på vilka andra nätverk ansökaren kunde kopplas till i form av associerat nätverk.

Ett nätverk som får stöd skall ha konstnärligt intressanta målsättningar och skall kunna formulera varför nätverket har intresse för nordiskt nätverksstöd. I en sådan formulering räcker det inte med endast ekonomiska argument. Nätverket kan vara personbundet eller institutionsbundet och det kan vara inom ett konstområde eller mellan flere konstområden. Nät- 
verket skall ha låga administrations-utgifter. Det är till fördel för nätverket om det har möjligheter att koppla sig till andra nordiska nätverk. En annan fördel är om nätverket är produktionsinriktat och om det har möjlighet att facilitera. Av de kortvariga nätverken krävs att nätverkets medlemmar skall ha haft kontakt med varandra innan de ansöker om stöd.

Av närverket krävs att en av dess medlemmar fungerar som ansvarig administratör ("Leading Partner") och att det finns en klar arbetsfördelning mellan de andra aktörerna i nätverket ("Project Partner"). Nordiska ministerrådet gör ett skriftligt avtal med nätverkets "Leading Partner", som ansvarar för att det årligen sammanställs en kort, offentlig rapport om nätverkets verksamhet. Vidare förutsätter Nordiska ministerrådet för internt bruk en administrativ rapport, som bl.a. skall redogöra för hur de beviljade medlen har använts och vilka kontakter och resultat nätverket har presterat.

\subsection{Modul 2: Samarbetscirkel/krets för konstnärsresidenser}

Modulen siktar på att förstärka de nordiska konstnärsresidensernas möjligheter att på ett aktivt sätt mottaga konstnärer från Norden och att utveckla sin verksamhet. Modulen siktar också på att göra det enklare för konstnärer från Norden att få tillgång till residens.

Inom denna modul kan residenser i Nordens ansöka om att ingå i en flerårig samarbetscirkel/ samarbetskrets som består av $8-16$ residenser inom olika konstformer. Residenserna står själva, enligt sina respektive kriterier, för valet av konstnärer. Varje residens får årligen ett stöd som skall täcka stipendier till 2 - 4 konstnärer. Stipendierna skall täcka resekostnader och uppehälle för en månad. Samarbetscirkelns/kretsens residenser erbjudes en resurs till gemensam informations-verksamhet, varmed nätverkets residenser kan informera om sina ansökningstider och kriterier, presentera residensen och de konstnärer som arbetar där. Dessutom skall de deltagande residenserna erbjudas möjlighet till en årlig gemensam träff, där de kan utbyta erfarenheter och höja sitt kunnande och sin kompetens. Nätverksträffarna skall också innehålla utbildning som skall hjälpa residenserna att utveckla sin verksamhet. Som utbildare kallas de bästa proffsen från Norden och internationellt.

För att delta i Samarbetscirkeln/kretsen väljs de konstnärsresidenser som har helt klara konstnärliga målsättningar. I Samarbetscirkeln kan också ingå residenser som är under utveckling och som fungerar regionalt. Varje residens skall kunna motivera sitt intresse för att delta i Samarbetscirkeln/kretsen (endast ekonomiska motiveringar duger inte). Residenset skall presentera sina fysiska lokaler, sina kontakter till det lokala konstlivet och vad de i övrigt kan erbjuda till konstnärer. Residen- 
set skall också presentera sina kriterier och sin urvalsprocess. Konstnärsresidenset kan delta i Samarbetscirkeln/kretsen endast en avtalsperiod.

Nordiska ministerrådet ingår ett skriftligt avtal med de residenser som ingår i Samarbetscirkeln/kretsen för t.ex. tre år. Avtalet definierar de möjligheter som samarbetscirkeln erbjuder till sina medlemmar, men också de förpliktelser som residenserna skall uppfylla. Medlemmarna i Samarbetscirkeln/kretsen skall årligen sammanställa en kort rapport om sin resp. verksamhet och verksamhetens innehåll. Rapporten är offentlig. De konstnärer som fått stipendium skall inte skriva rapport, men de skall redovisa sina utgifter mot verifikat.

\subsection{Modul 3: Produktionsinriktad residensverksamhet (Artist-in-Production)}

Modulens syfte är att utveckla produktionsinriktad residensverksamhet $\mathrm{i}$ Norden. Produktionsresidens erbjuder konstnären möjlighet till verkproduktion och att det färdiga verket presenteras. Utvecklingen av konstnärens verk under residensperioden stöds genom att konstnären har ett nära samarbete med t.ex. en kurator eller producent. Genom produktionsresidenserna förstärks konstfältet i Norden så att det står sig starkare internationellt.

De nordiska konstnärerna har goda möjligheter att visa upp sina verk i Norden, men endast få möjligheter till att producera verk i ett nordiskt samarbete. I dagens läge måste de nordiska konstnärerna tävla om internationella produktionsresidenser för att kunna producera sina verk. På lång sikt kommer produktionsresidenserna att kunna bidra till tvärkonstnärliga produktioner. Ofta är det så att endast de konstnärer som har haft möjlighet att fördjupa sig i sin egen konstart har goda möjligheter att samarbeta med andra konstarter.

För den produktionsinriktade residensverksamheten utvecklas de nuvarande nordiska gästateljéerna så att de utgör centers som profilerar sig enligt de olika konstarterna och kan utvecklas till kompetenscenters. Produktionsresidenserna koncentreras till dessa centers. Ett center kan profilera sig t.ex. på ny media, ett annat på arkitektur och design, ett tredje på musik, ett fjärde på litteratur etc. Varje center skall ha en kärna, som är en nationell aktör, som har som partners flera nationella aktörer. Dessa nationella och specialiserade centers utgör tillsammans ett nordiskt nätverk, som t.ex. möjliggör ett utbyte av utställningar, andra verkkategorier etc.

Av dessa centrers krävs att de har en kompetent organisation, kontakter i det lokala konstlivet och att de har ett innehållsligt program. Dessa centers beviljas resurser till produktionsresidenserna och de uppmanas till samarbete sinsemellan. Nordiska ministerrådet ingår ett skriftligt avtal med centret. Avtalet definierar centrets rapporteringsplikt och den admi- 
nistrativa arbetsfördelningen. Centren erbjuds en gemensam resurs för informationsverksamhet.

För konstnärerna i produktionsresidenserna erbjuds möjlighet att reflektera över sitt arbete. Med konstnären kan t.ex. följande arbeta : en filosof, en forskare eller en annan konstnär som står i dialog med konstnären om hans/hennes verk som är under produktion. Kring denna dialog kan centret t.ex. arrangera en föreläsningsserie eller annan diskursiv verksamhet som leder till att konstnärens verk kan möta en publik. Det färdiga verket skall visas i residensets egna lokaler eller i samarbete med någon lokal konstinstitution.

Den konstnär som har valts till produktionsresidens och de experter som arbetar med honom/henne beviljas residensstipendium, som täcker resor och uppehälle. Dessutom får konstnären ett produktionsstipendium, som täcker produktionsutgifterna (lokaler, teknisk utrustning och tekniskt stöd, material etc) och det att verket visas offentligt. Konstnären garanteras 2 - 6 månader och experterna 2 - 4 veckors arbete i produktionsresidens. Konstnären skall ha möjlighet att genomföra sitt arbete i två delar. Den första kan gälla research och den andra delen kan vara för själva produktionen.

Varje center väljer själv de konstnärer som får delta, men det är ändå viktigt att urvalsprocessen också får en internationell synvinkel. En av de som bedömer ansökningarna skall komma från ett land som ligger utanför Norden. Denna bedömare byts ut årligen för att så många utländska experter som möjligt skall få möjlighet att via detta uppdrag bekanta sig med ett brett urval av nordiska konstnärer. Centren måste själva sörja för att urvalsprocessen är transparent.

Centren måste också gå med på att produktionsresidens kan sökas av konstnärer som inte kommer från Norden. Det är viktigt att utländska konstnärer kan delta i den samnordiska konstkontexten och inte endast via utbytesprogram. Det internationella inslaget skall inte bindas vid kvoter, utan ansökningsvillkoren kan definieras så att man i sin ansökning skall beskriva både den nordiska och internationella dimensionen i sitt projekt.

\subsection{Modul 4: Mobilitetstöd}

Modulen syftar till att stöda det nordiska konstfältets mobilitet för personer och den riktar sig till hela konst- och kulturfältet i Norden: konstnärer, skönlitterära författare, översättare, kuratorer, kulturredaktörer och kulturforskare. Den sökande skall kunna verifiera professionell verksamhet i minst tre år eller skall ha åtminstone ett konstnärligt högtstående "genombrott". Inga åldersgränser. Statliga tjänstemän eller tjänsteman vid statlig myndighet kan inte söka. 
I denna modul kan man ansöka om vistelsestipendium till ett annat land i Norden. Modulen beviljar inte utgifter för resor, men för uppehälle. Stipendiet täcker utgifterna för 10 dygns boende enligt en genomsnittlig beräkningsgrund. Stipendiet har två kategorier: huvudstäderna och resten av landet. I rapporteringen krävs inte verifikat, men stipendiaten skall ge en rapport över de kontakter som har fötts och om möjligheter till fortsatt arbete.

Modulen beviljar inte resestipendier från ett nordiskt land till ett annat. De som söker om mobilitetsstöd uppmanas att söka resestöd hos de bilaterala fonderna eller hos nationella fonder och program.

Det enda undantaget angående resestöd gäller resor från och till VästNorden. Från denna modul kan man ansöka om resestipendier från VästNorden (Färöarna, Grönland och Island) till de andra nordiska länderna samt vice versa. Resestipendiet storlek definieras på basen av ansökningens budget. Det finns ingen övre gräns för dessa stipendier, men i sin rapport skall stipendiaten kunna redovisa alla resekostnader med verifikat.

Syftet med vistelsen i ett annat nordiskt land är t.ex. planering av ett nytt projekt, utbyte av idéer eller kompetensökning inom det egna professionella kunnandet. Det kan också gälla att delta i residens, festival, seminarium eller möte. Vistelsens syfte kan inte vara studentutbyte eller det man visar upp ett verk.

Ansökningarna skall vara konkreta och målsättningarna skall bidra till tvärkonstnärliga möten, till att öppna upp för arbetsmöjligheter i ett annat nordiskt land eller för att initiera samarbete med kolleger från Norden. Ansökningen blir tyngre om ansökaren har möjlighet att uppträda offentligt i det land han/hon besöker så att en större grupp människor kan ta del av besöket.

Modulen skall kontinuerligt vara öppen för ansökningar, som behandlas en gång per månad. Modulen skall ha en hemsida, som bl.a. skall ha länkar till resestipendieprogram i Norden. Modulen skall också ha en elektronisk "inlärningsmiljö" (t.ex. www.moodle.org) som alla stipendiemottagare länkas upp mot så fort de har fătt ett positivt besked om mobilitetsstöd. Detta möjliggör att stipendiaten kan komma i kontakt med andra stipendiater i samma land, få del av tidigare erfarenheter, chatta. Också de Nordiska Husen och Instituten i Island, på Grönland, Färöarna, i Finland och på Åland kan hjälpa stipendiaten med att skapa kontakter. 


\section{Styrningsmodell}

"De fyra modulernas program” styrs på så sätt att den konstnärliga och administrativa styrningen skiljes åt. De tär viktigt för att programmet inte skall bli för allmänt till sin karaktär. Den konstnärliga ledningen skall kunna personifieras och den administrativa ledningen skall ha kopplingar till den politiska beslutsfattningen.

\subsection{Programgrupper}

För tre av modulerna inrättas var sin programgrupp, som kallas av de nordiska kulturministrarna (MR-K). En programgrupp svarar för modulens konstnärliga innehåll och för valet av de som erhåller stöd (personer, nätverk, organisationer). Programgruppen behandlar ansökningarna så rättvist som möjligt, vilket bl.a. innebär att alla i programgruppen bekantar sig med alla ansökningar. Programgruppen träffas 1 - 2 gånger i året. Resten av programgruppens arbete och beredning kan se via telefonmöten och via skriftliga utlåtanden.

För nätverkstödet inrättas en programgrupp, som består av tre personer. Till medlemmar kallas erkända konstnärer som har profilerat sig med en bred konstnärlig profil och som har erfarenhet av konstnärligt ledningsarbete. Programgruppens medlemmar kan konsultera med experter som står utanför programgruppen. Programgruppens mandat är tre år och hela programgruppen skall bytas ut när mandatperioden tar slut.

För konstnärsresidensernas samarbetscirkel/krets inrättas en programgrupp, som består av fyra personer. Till medlemmar kallas professionella med ett gediget kunnande om residensverksamhet. En medlem kan representera bildkonst, en annan litteratur, en tredje musik och den fjärde performing arts. Programgruppens uppdrag är att välja de residenser som skall delta i samarbetscirkeln/kretsen, men varje residens väljer själv konstnärer enligt sina kriterier. Programgruppen deltar varje år i det medlemsmöte som de deltagande residenscentren arrangerar. Programgruppens mandatperiod är tre år och hela gruppen skall bytas ut vid periodens slut.

För modulen för mobilitetsstöd till personer inrättas en programgrupp som består av fyra personer. Till medlemmar kallas erkända professionella från konstfältet i Norden. En medlem kan representera de professionella konstnärerna, en annan produktion ( t.ex. en producent eller kurator), en tredje distributionen (en representant för festivaler eller kulturcentrum) och den fjärde kunde representera konstnärförbunden. Pro- 
gramgruppens mandatperiod är tre år och hela programgruppen skall bytas ut när mandatperioden tar slut.

\subsection{Ledningsgrupp}

Förutom programgruppernas inrättas en ledningsgrupp som består av 8 personer, en representant för varje land och för varje självstyrande område. De nordiska kulturministrarna (MR $-\mathrm{K})$ utser styrningsgruppen efter att ha inhämtat förslag från de nordiska konstnärsorganisationernas takorganisationer och från andra centrala organisationer inom det nordiska konstfältet.

Styrningsgruppens uppdrag är att bedöma varje nytt modulprogram, dess effekt och verkningsfullhet och hur programmet kan nå sina målsättningar. Styrningsgruppen behandlar administrativa rapporter från modulerna och annan feed back. Styrningsgruppens centrala frågor är: vilken konstnärlig utveckling har programmet stött? På vilket sätt har programmet berikat kultursamarbetet i Norden? Styrningsgruppen sammanställer årligen en rapport om programmets verkningsfullhet till kulturministrarna.

Styrningsgruppen fungerar som ett beredande organ för Nordisk Kulturforum där det kan rapportera om programmens verkningar och resultat. Styrningsgruppen kan också föreslå tema och diskussionsämnen för Nordisk Kulturforum. Styrningsgruppen kan också göra rekommendationer till kulturministrarna och på förhand behandla dem på Nordisk Kulturforum. Styrningsgruppen sammanträder endast en gång i året. Styrningsgruppen väljer ordförande och viceordförande inom sig och dessa skall delta i Nordisk Kulturforum.

\subsection{Beredning av beslut för produktionsinriktad residensverksamhet}

För den produktionsinriktade residensverksamheten inrättas ingen särskild programgrupp, för hela modulen kräver ett omfattande beredning. För att utveckla produktionsresidenserna behövs det först en nationell diskussion om vilken konstmiljö/konstfält länderna vill och kan profilera sig mot. Det behövs också en ingående diskussion och vilka aktörer som kunde fungera som nationella centers, vilka samarbetspartners som kunde delta $\mathrm{i}$ verksamheten och om finansieringen. I planeringen måste man ta vara på de bästa utländska exemplen ("Best Practise"). Efter de nationella diskussionerna behövs det en nordisk diskussion om vilka centers som skall väljas. Först efter detta kan Nordiska ministerrådet förbereda saken för kulturministrarna. 


\section{Stödfunktioner och service}

För att ta hand om stödfunktioner för "De fyra modulernas program " behövs det en liten och energisk enhet med hög professionalism. Enheten behöver en ledare och dessutom behövs det producenter och sekreterarinsatser. Enheten skall i stor omfattning röra sig ute på det nordiska konstfältet och med sin kompetens och professionalism bege sig dit där aktörerna befinner sig. Enhetens arbetsspråk är de skandinaviska språken och engelska. Enheten har flera funktioner som kompletterar varandra.

- $\quad$ Sam - aktion: Enheten kan fungera som sam-aktör men den har inga egna programmålsättningar. Den kan sammanföra olika organisationer och konstnärsgrupper över de nationella gränserna, fungera som förmedlare, konsultbistånd och som knutpunkt.

- Information: Enheten svarar för en koncentrerad informationsresurs. Enheten skall främst arbeta med nätinformation som portal, nätsidor, elektroniska produkter, elektronisk portofolio och med elektroniska diskussionskanaler/miljöer. De nätverk som erhåller'nätverksstöd, samarbetscirkelns/kretsens medlemmar och centren för produktionsinriktad residensverksamhet deltar i produktionen av informationsmaterial tillsammans med enheten.

- Innovation: Enheten svarar för utveckling av modulprogrammen, men koncentrerar_sig på de program som håller på att avslutas och som därför är aktuella och kan utvecklas på basen av de erfarenheter som har insamlats. När förnyade och förbättrade moduler skall startas upp är det nödvändigt med diskussioner och analyser i samarbete med konstfältet i Norden.

- Administration: Enheten ko-ordinerar modulprogrammets årsplanering, tar emot ansökningar till modulerna, förbereder programgruppernas och styrningsgruppens möten och tar sig an programmets ekonomiförvaltning. 


\section{Utvecklingsmöjligheter för de nuvarande nordiska mobilitetsprogrammen}

\subsection{Skandinaviska föreningen i Rom}

Föreningens ekonomi har en längre tid varit osäker och i de diskussioner jag har haft är det uppenbart att fältet har motstridiga synpunkter på verksamheten. Rom har sina supporters ("Norden träffas utanför Norden", "Det är viktigt med avstämd arbetsgemenskap"). Men det finns också kritiska röster (" En konservativ, romantisk konstnärsbild", "Om det finns pengar så $\mathrm{OK}$, den är nog en uppskattad resurs, men hellre skicka konstnärer till professionella program för det är bättre för konstens utveckling".)

Skandinaviska föreningen i Rom kan - om man så önskar - kopplas till konstnärsresidensens samarbetscirkel/krets. För att det skall leda till ett bra resultat krävs det emellertid en del justeringar och förändringar. Roms verksamhetsidé måste breddas så att den inte endast fungerar som gästrum utan dess verksamhetsidé måste få en styrning mot residensprogram. Samtidigt måste nya verksamhetsformer utvecklas och det är skäl att utveckla ansöknings - och urvalsprocessen. Det är tänkbart att det den sakkunniggrupp/organ som väljer ut de deltagande konstnärsresidenserna kunde ta ett ansvar för utvecklingen av Roms verksamhet och ansöknings- och urvalsprocessen. Skandinaviska föreningen i Rom behöver en ny styrelse, som kan ta ansvar för både innehåll och administration. Också personalfrågan måste lösas i enlighet med en ny verksamhetsidé.

\subsection{Nordic Resort}

I det nya modulprogrammet är det inte Nordiska ministerrådet som aktivt utvecklar programmets innehåll, utan idéerna och programinnehållen kommer från konstfältet i Norden. På dessa förslag och programinnehåll svarar Nordiska ministerrådet genom att erbjuda möjligheter. Nordic Resort är ett program som utvecklats av Nordiska ministerrådet/NordScen. Därför vore det principiellt viktigt att föra en dialog med konstfältet om vilken typ av residensverksamhet man önskar: skall det vara med fokus på produktion eller forskning? Ifall det finns efterfrågan på program i stil med Nordic Resort bör programmet fortsätta, men då 
måste man finna en värdinstitution som kan ansvara för programmets innehåll och förvaltning.

En möjlighet till dialog med performing arts -fältet erbjuder sig i slutet av år 2006 då man i Helsingfors arrangerar IETM:s nätverkskonferens. IETM (Informal Europan Theatre Meeting), Visiting Arts, PEARL ( Performing Arts Employers' League Europe ), Informationscentralen för Finlands teater och Goethe-Institutet har ansökt om EU- medel för detta nätverksmöte med temat "2006 - The Year of Mobility". Ca 700 personer kommer att delta. Nordiska ministerrådet kunde föreslå att nätverkskonferensen också skulle arrangera en temadiskussion om residensverksamhet för teaterfältet i Norden.

\subsection{Dalsåsen}

Dalsåsen kan kopplas till det nordiska residensprogrammet för produktionsinriktade residenser och utgöra ett nytt kompetenscenter. Dalsåsen kunde profilera sig inom de områden där den har en stark tradition. Inom områdena konsthantverk, formgivning och design finns det stor efterfrågan på nordiskt sammanhang och kontakter. Dalsåsen med sitt isolerade läge djupt inne i skogarna kunde utvecklas till ett sådant center och Dalsåsen kan utnyttja sina särdrag, "arktisk dimension" och genom att rikta verksamheten in mot sig själv och inte utåt - bort från Dalsåsen. Dalsåsen måste skapa sin egen miljö och dynamik genom att inbjuda experter och konstnärer från olika håll och från flera länder utanför Norden att mötas.

Dalsåsen kan samla grupper för kvalitativt skapande; workshops, idéutveckling och produktion. Dalsåsen kan arrangera diskussioner inom de områden som Dalsåsen väljer att arbeta med, t.ex. rundabords-samtal, eller möten och kritisk dialog mellan kuratorer och konstnärer. Vistelserna kunde omfatta 1 - 2 veckor och programmen borde inte fokusera på projekt som varar i flera månader. Dalsåsen kan stå i dialog med andra centers som arbetar med bildkonst och detta kunde öppna nya möjligheter för de konstnärer som gästar Dalsåsen.

För att Dalsåsen skall kunna inlemmas i det nya modulprogrammet måste Dalsåsen få en nationell värdinstitution, som kan ta ansvar för dess verksamhet och utveckling samt administrationen. Nordiska ministerrådet gör ett avtal om detta med den nationella värdinstitutionen. Dalsåsen behöver också fler gästrum/gästbostäder så att den kan ta emot fler gäster samtidigt. Detta skulle leda till större dynamik i verksamheten och bidra till att Dalsåsen skulle få ut mycket mer av de lokaler och arbetsutrymmen de disponerar över. 


\subsection{Sveaborg}

Sveaborg lämpar sig väl som miljö för ett av de nya produktionsinriktade residensprogrammen. Sveaborg kunde t.ex. fokusera på ny media och videokonst. Även för Sveaborgs del är det avgörande att finna en nationell värdinstitution, som ansvarar för verksamheten och som Nordiska ministerrådet kan ingå ett avtal med på samma sätt som Nordiska ministerrådet ingår avtal med andra residenscenters. För att Sveaborg skall kunna fungera som ett produktionsinriktat center måste det utrustas med sådan teknik som motsvarar de krav som centrets inriktning/verksamhet kommer att ha. Eftersom Sveaborg ligger på en ö utanför Helsingfors är det nödvändigt för residensverksamheten att centret har en kontaktperson ute på Sveaborg. 


\section{Bilaga 1. Lista över konsulterade sakkunniga}

Anthin Ramon, verkställande direktör, Visby Internationella Tonsättarcentrum Antti-Poika Jaakko, direktör, Sveaborgs förvaltningsnämnd Sigurdsson Adalsteinn Ásberg, ordförande, RSÍ (Islands författarförening) Birkeland Sven Åke, konstnärlig ledare, BIT Teatergarasjen Bravinger Håkan, internationell sekreterare, Sveriges Författarförbund Curman Peter, ordförande, KLYS (Konstnärliga och Litterära Yrkesutövarnas Samarbetsnämnd)

Forslund John Erik, senior councel, Sveriges Författarförbund

Gustafson Lars Olof, Konstnärsnämnden, handläggare, Sveriges bildkonstnärsfond

Hjörvar Helga, direktör, Nordatlantens Brygge

Jaukkuri Maaretta, professor, Kunstakademiet i Trondheim

Kokko Irmeli, tf. kurator, FRAME (Finnish Fund for Art Exchange)

Kruckow Marianne, centerchef, Kunststyrelsens Litteraturcentret

Kuzman Marta, direktör, OCA (International Studio Programme Oslo)

Larsson Ann, kanslichef, Konstnärsnämnden

Lind Maria, Konstnärsnämnden, direktör, IASPIS (International Artist Studio Program in Sweden)

Madsen Gunnar, direktör, ROSA (Dansk Rock Samråd)

Muukkonen Marita, koordinator, FRAME (Finnish Fund for Art Exchange)

Ólafsson Porgeir, avdelningschef, Islands kulturministerium

Pasternak Lena O., direktör, Östersjöns författar- och översättarcentrum i Visby

Pousette Johan, direktör, BAC-konstcentret (Baltic Art Center)

Rustanius Jaakko, direktör, HIAP (Helsinki International Artist-in-Residence Programme) Sandbeck Sten Are, programkoordinator, OCA (International Studio Programme Oslo)

Schwanck Iris, direktör, FILI (Informationscentralen för Finlands litteratur)

Seppälä Riitta, verkställande direktör, TINFO (Informationscentralen för teater i Finland)

Sigeland Helen, konsult, Svenska Institutet

Skipper Lene, projektmedarbetare, ROSA (Dansk Rock Samråd)

Suomi Riikka, planerare, Ateljéstiftelsen för Konstnärsgillet i Finland

Sutinen Virve, producent, Kiasma-teatern

Söderlund Mats, ordförande, Sveriges Författarförbund

Thorlacius Áslaug, ordförande, SÍM (Islands bildkonstnärsförening)

Østerby Anette, centerchef, Kunststyrelsens Billedkunstcentret 


\section{Bilaga 2. Lista över konsulterade nordiska organisationer}

Abrahamsen Svend, verkställande direktör, Nordisk film \& TV Fond Berndtsson Anders, direktör, Nordens institut på Grönland Ericsson Anne-Sofie, direktör, NordScen

Etelä Nina, rådgivare, Nordisk Innovationscenter Faerevaag Eva, projektkonsult, Nordisk film \& TV Fond Gelin Cecilia, direktör, NIFCA

Gislén Ylva, projektchef, NordScen

Gunnarsdóttir Elísabet, direktör, NKD

Heiskanen Teppo, direktör, Nordiska informationskontoret i Riga

Holm Niels, direktör, Nordens hus på Färöarna

Kaurinkoski Mitro, projektkoordinator, NIFCA

Klement Kalli, direktör, Nordiska informationskontoret i Tallinn

Langeland Asbjørn, direktör, Nordbok

Löfstedt Helen, föreståndare, Konstnärskollegiet i Rom

Nilsson Petra, rådgivare, Nordisk Innovationscenter

Petersen Refslund Hanne, direktör, Nordiska informationskontoret i Vilnius

Rydberg Bo, generalsekreterare, NOMUS

Simonsen Stefan, direktör, Nordens institut på Åland

Tropa Ginta, kulturrådgivare, Nordiska informationskontoret i Riga

Urmaneita Brigita, kulturrådgivare, Nordiska informationskontoret i Vilnius

Vain Eha, kulturrådgivare, Nordiska informationskontoret i Tallinn

Wettmark Ellen, projektkoodinator, NIFCA 


\section{Bilaga 3. Enkät till nordiska konstnärsorganisationer - de som svarat och frågeformulär}

Svar från följande konstnärsorganisationer:

- Billedkunstnernes Forbund / Bkf

- Konstindustriföreningen OR-

Dansk Artist Forbund / DAF

- Dansk Komponistforening

- Danske dramatikeres forbund

- Danske Kunsthåndværkere

- Finlands Arkitektförbund rf. / SAFA

- Finlands Konstnärsgillet

- Finlands Regissörförbund

- Finlands Skådespelarförbund

- Finlands Svenska Skådespelarförbund rf.

- Finlands Tonsättare rf.

- Finlands översättar- och folkförbund rf.

- $\quad$ Forum Artis rf.

- Föreningen Svenska Tecknare

- Föreningen Svenska Tonsättare

NAMO

- Leiklistarsamband Íslands

- Norsk Filmforbund

- $\quad$ Norsk Oversetterforening

- Norsk Skuespillerforbund

- Norske Billedkunstnere

- Norske Dansekunstnere, forbundet for dansere, koreografer og pedagoger

- Norske Dramatikeres Forbund

- $\quad$ Norske Kunsthåndverkere

- Samband íslenskra myndlistarmanna - SÍM

- Sveriges Författarförbund

- Sveriges Regissörer / Sre

- Tonskaldafélag Íslands

- Ålands slöjd och konsthantverkare rf.

Hemland

- Finlands Danskonstnärsförbundet

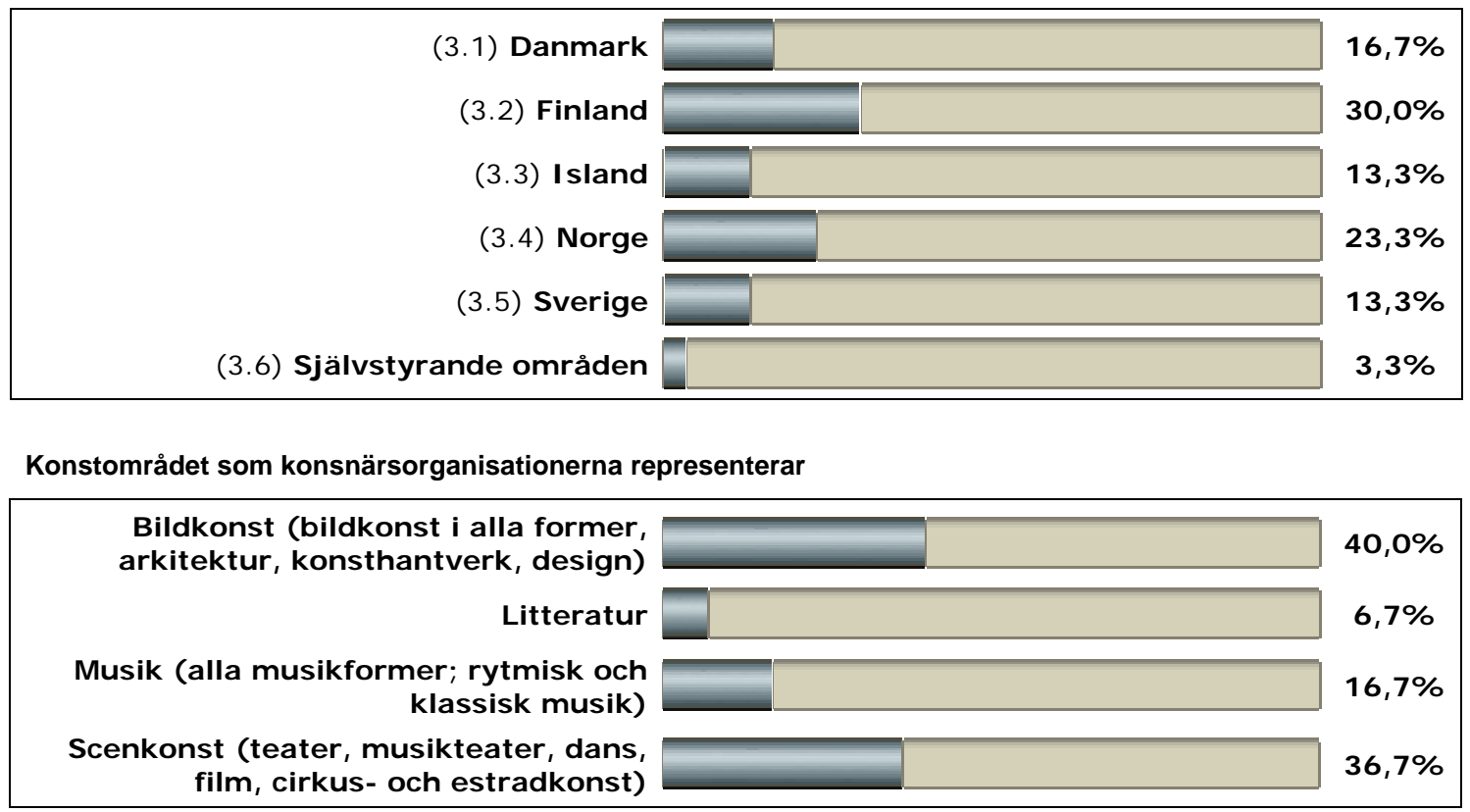




\section{Konstnärsorganisationer och mobilitet}

Det nordiska kultursamarbetet reformeras under år 2006 och skall från och med 2007 fungera med nya strukturer, som bl.a. omfattar tidsbundna tematiska program samt mobilitets- och residensprogram för konstnärer och kulturarbetare. Det nya mobilitets- och residensprogrammet för personer skall år 2007 ersätta de program som utvecklats och administrerats av Sleipnir, Nifca, Dalsåsen, NordScen och andra nordiska organ.

Som en del av mitt utredningsarbete hoppas jag att ni har möjlighet att svara i denna elektroniska enkät. Sista svarsdagen är fredagen den 3. februari. Efter detta datum mottar det elektroniska programmet tyvärr inte ängre nya svar.

1) Mottagarens namn och ställning *

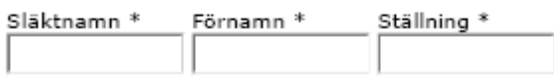

2) Konstnärsorganisationens namn*

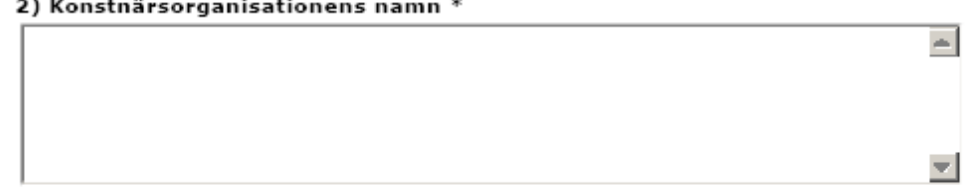

3) Konstnärsorganisationens hemland *

C Danmark

Finland

C Island

Norge

C sverige

Självstyrande områden

4) Konstområdet som konstnärsorganisationen representerar *

Bildkonst (bildkonst i alla former, arkitektur, konsthantverk, design)

C Litteratur

Musik (alla musikformer; rytmisk och klassisk musik)

Scenkonst (teater, musikteater, dans, film, cirkus- och estradkonst)

5) Begreppet mobilitet

Förklara enligt din mening vad begreppet mobilitet innebär inom det konstområde som du representerar.

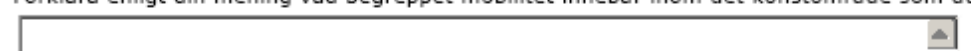


6) Begreppet residens

Förklara enligt din mening vad begreppet residens betyder inom det konstområde som du representerar.

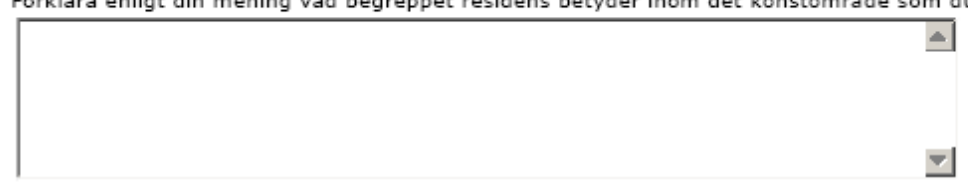

\section{7) Kort situationsbeskrivning}

Beskriv enligt din mening på vilka sätt verksamhetsmiljön och arbetssätten håller på att förändras inom det konstområde som du representerar.

$\Delta$

\section{8) Behov och nordisk finansiering}

Vilka behov finns det för mobilitets- och residensprogram inom det konstområde som du representerar och var kan enligt din mening en nordisk insats göra en skillnad?

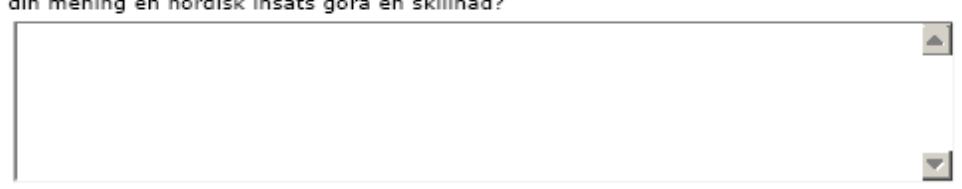

9) Fungerande nätverk

Namnge inom det konstområde som du representerar nordiska nātverk som du anser att fungerar speciellt bra.

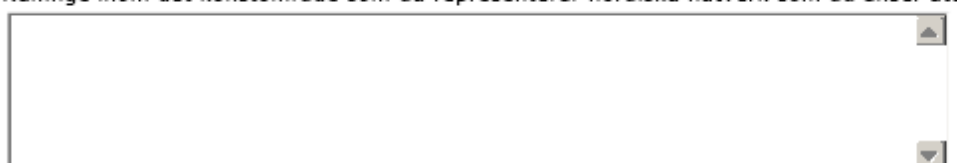


10) Värdera följande pâstâenden

\begin{tabular}{|c|c|c|c|c|c|}
\hline $\begin{array}{l}\text { Helt av } \\
\text { annan } \\
\text { åsikt }\end{array}$ & $\begin{array}{l}\text { Nāstan } \\
\text { av annan } \\
\text { åsikt }\end{array}$ & $\begin{array}{l}\text { Lite av } \\
\text { annan } \\
\text { åsikt }\end{array}$ & $\begin{array}{l}\text { Lite av } \\
\text { samma } \\
\text { åsikt }\end{array}$ & $\begin{array}{c}\text { Nāstan } \\
\text { av } \\
\text { samma } \\
\text { åsikt }\end{array}$ & $\begin{array}{c}\text { Helt av } \\
\text { samma } \\
\text { åsikt }\end{array}$ \\
\hline 0 & 0 & 0 & 0 & 0 & 0 \\
\hline 0 & 0 & 0 & 0 & 0 & 0 \\
\hline 0 & 0 & 0 & 0 & 0 & 0 \\
\hline 0 & 0 & 0 & 0 & 0 & 0 \\
\hline 0 & 0 & 0 & 0 & 0 & 0 \\
\hline 0 & 0 & 0 & 0 & 0 & 0 \\
\hline 0 & 0 & 0 & 0 & 0 & 0 \\
\hline 0 & 0 & 0 & 0 & 0 & 0 \\
\hline 0 & 0 & 0 & 0 & 0 & 0 \\
\hline 0 & 0 & 0 & 0 & 0 & 0 \\
\hline 0 & 0 & 0 & 0 & 0 & 0 \\
\hline 0 & 0 & 0 & 0 & 0 & 0 \\
\hline 0 & 0 & 0 & c & 0 & 0 \\
\hline
\end{tabular}

Tack för att du svarade på frågorna.

$\lceil$ Jag vill skicka svaren

Skicka 
Bilaga 4. Enkät till bilaterala fonder och vänskapsföreningar - de som svarat och sammandrag av svaren

Sammandrag av elektronisk enkät (27.1.2006)

Utredare: planeringschef Riitta Heinämaa och assistent Mervi Sainio

Svarare

\begin{tabular}{|c|c|c|c|}
\hline \multicolumn{3}{|c|}{ Namn och fondens namn } & \multirow[b]{2}{*}{ Kulturförvaltningen i Stockholm stad / Nordiskt kultursamarbete } \\
\hline Boulogner & Yvonne & Chefssekreterare & \\
\hline \multirow{4}{*}{$\begin{array}{l}\text { Ljunggren } \\
\text { Rajavuori }\end{array}$} & \multirow{4}{*}{$\begin{array}{l}\text { Anders } \\
\text { Raili }\end{array}$} & \multirow{4}{*}{$\begin{array}{l}\text { Fonddirektör } \\
\text { Fondsekreterare }\end{array}$} & Svensk-norska samarbetsfonden \\
\hline & & & Kulturfonden för Sverige och Finland \\
\hline & & & Svensk-isländska samarbetsfonden \\
\hline & & & Svensk-danska kulturfonden \\
\hline \multirow[t]{4}{*}{ Kronman } & \multirow[t]{4}{*}{ Gunvor } & Fonddirektör & Kulturfonden för Sverige och Finland/det finländska utskottet \\
\hline & & \multirow[t]{3}{*}{ Generalsekreterare } & Kulturfonden för Finland och Norge \\
\hline & & & Kulturfonden för Finland och Danmark \\
\hline & & & Kulturfonden Island-Finland \\
\hline Ravnsfjall & Jógvan & Museumsleder & Dansk Færøsk Kulturfond \\
\hline Sippel & Agnete & Pol. Kand & Fonden för Färöarna \\
\hline Springborg & Peter & Lektor & Dansk-islandsk forbundsfond \\
\hline Vaagland & Per Ivar & Generalsekretær & Fondet for dansk-norsk samarbeid \\
\hline
\end{tabular}

1. Vilken typ av utbyte finns det inom de bilaterala fonderna (t.ex. konkreta rese- och vistelsestipendier eller andra former av stöd till utbyte)?

- Kulturförvaltningen i Stockholm stad / Nordiskt kultursamarbete Vistelsestipendium - Resestipendium - Veckostipendium

- Kulturfonden för Finland och Norge

- Kulturfonden för Finland och Danmark

- Kulturfonden Island-Finland

Resestipendier à 300-700 euro/person. Stipendier för bl.a. översättning/konstnärligt arbete à 500-2000 euro/person.

- Svensk-norska samarbetsfonden

Fonden har tre olika sorts stöd:

1. Projektstöd för svensk-norskt utbyte, samarbete.

2. Vistelsestipendier till Voksenåsen i Oslo, respektive Hässelby slott i Stockholm .

3. Konstnärsstipendier (bildkonst) till Kunstnerhuset i Svolvaer respektive Gerlesborgsskolan i Bohuslän. 
- Kulturfonden för Sverige och Finland/det finländska utskottet Fonden beviljade ca 250 veckor för år 2005 till ca 210 personer för en eller två veckors vistelse i Stockholm. Vistelsestipendierna täcker en kostnadsfri vistelse på hotell i Stockholm. Därtill får stipendiaterna ett resebidrag (125 euro) och ett måltidsbidrag (15 euro/dag). Fonden beviljar också vistelser till andra orter i Sverige (850 euro/vecka). År 2005 beviljades 32 veckor för vistelse på andra orter motsvarande 27.200 euro (ca 30 personer). Allmänna bidrag: Fonden beviljade ca 500.000 euro för år 2005 (inkl. vistelser på andra orter i Sverige). Bland dessa bidrag finns t.ex. grupper som reser till Sverige i samband med olika samarbetsprojekt, men också privata personer. De reser till Sverige eller inbjuds till Finland för att delta i olika mindre eller större bilaterala projekt (t.ex. konstutställningar, seminarier, språksamarbete, dans- och musikevenemang).

- Fonden för Färöarna

Rese- och vistelsestipendium för en vecka i Finland. En stipendiat inbjuds ca vartannat år.

- Kulturfonden för Sverige och Finland

Fonden arbetar med två utskott (det finska sekretariat finns på Hanaholmen). I Sverige utdelas: projektstöd (ca 1,8 milj SEK/år) vistelsestipendier till Hanaholmen och andra orter i Finland (600 000 - 800 000 SEK per år) samt kulturpris ( 3 x 35000 SEK/kan ej sökas).

- Svensk-isländska samarbetsfonden

Fondens utdelningsprofil fastställs årligen. Under senare år har fonden utlyst för ansökan ett antal resestipendier för enskilda personer á 5000 SEK. Därutöver kan fonden ge projektstöd till speciella projekt med varierande belopp eller genom att avsätta pengar för initiering av ett projekt, t ex Svenska veckan i Reykjavík 2003, som sedan, på fondens initiativ, fick stöd även från Sveriges och Islands regeringar och andra samarbetspartners.

- Svensk-danska kulturfonden

Fonden har inte kunnat utdela bidrag under ett antal år pga dålig ekonomi. Existensen har markerats genom att fonden har utdelat kulturpris. Fonden disponerar årligen ett belopp från Evers \& COs fond för svenska vetenskapsmäns studier i Danmark. Fonden har åtagit sig att utlysa dessa stipendier i högskolorna i Sverige samt att avge yttrande till Evers som beslutar om utdelningen. Avser oftast kortare tids studier/studiebesök i Danmark i samband med pågående studier vid högskola/universitet i Sverige. Beviljas inte som komplement till mer stadigvarande högskolestudier i Danmark.

- Dansk-islandsk forbundsfond

Fondet har tre formål: 1. styrke den åndelige forbindelse mellem landene. 2. Fremme islandsk forskning og videnskab. 3. støtte islandske 
studerende. Der er ikke afsat et fast beløb til rejse- og opholdsstipendier, men ved siden af studiestøtte til islandske studerende i Danmark (formål 3) gives støtte til rejser til og fra Island, især under formål 1.

- Dansk Færøsk Kulturfond

Støtte til rejse, ophold, og andre udgifter i forbindelse med kunst- og kultursamarbejde mellem Færøerne og Danmark, eller kunst- og kulturbesøg begge veje. Også ydes der studierejselegat til to studerende en gang om året, studierejse fra Danmark til Færøerne og omvendt.

- Fondet for dansk-norsk samarbeid

Oppholdsstipend for enkeltpersoner til Lysebu for dansker og Schæffergården for nordmenn. Oppholdsstipend for grupper til Lysebu for dansker og Schæffergården for nordmenn. Utveksling av kunstutstillinger med norsk kunst på Schæffergården og dansk kunst på Lysebu.

2. Vilka ekonomiska resurser finns avsatta för dessa ändamål?

- Kulturförvaltningen i Stockholm stad / Nordiskt kultursamarbete

För rese- och veckostipendier finns medel avsatta för inne-varande år samt år 2007 och avser 2 ansökningstillfällen per år. Ca 400 - 450 tkr per kalenderår.

- Kulturfonden för Finland och Norge

- Kulturfonden för Finland och Danmark

- Kulturfonden Island-Finland

Kulturfonden för Finland och Norge/finländsk fonddel: ca 40.000 euro. Kulturfonden för Finland och Danmark/finländsk fonddel: ca 35.000 euro. Kulturfonden Island-Finland: ca 28.000 euro.

- Svensk-norska samarbetsfonden

1. Projektstöd 200000 SEK (2006) 2. Vistelsestipendier, Voksenåsen 298000 SEK. Vistelsestipendier till Hässelby slott 20000 SEK. Resebidrag i anslutning till ett vistelsestipendium 50000 SEK. 3. Konstnärsstipendier 100000 SEK.

- Kulturfonden för Sverige och Finland/det finländska utskottet Vistelser 2006 års budget: drygt 200.000 euro. Allmänna bidrag 2006 års budget: ca 500.000 euro.

- Fonden för Färöarna

Från 1.000 euro till 1.500 euro.

- Kulturfonden för Sverige och Finland

se ovan

[Fonden arbetar med två utskott (det finska sekretariatet finns på Hanaholmen). I Sverige utdelas: projektstöd (ca 1,8 milj SEK/år) vis- 
telsestipendier till Hanaholmen och andra orter i Finland (600 000 800000 SEK per år) kulturpris (3 x 35000 SEK/kan ej sökas)]

- Samarbetsfonden Sverige-Island 2005 utdelades 55000 SEK i resebidrag.

- Svensk-danska kulturfonden Årsanslaget kan variera från 20000 DKK till 30000 DKK.

- Dansk-islandsk forbundsfond Fondet råder kun over en begrænset sum til uddeling, således at støtten normalt kun omfatter dækning af rejse.

- Dansk Færøsk Kulturfond

Af fondets økonomiske værdier kan der årligt udbetales ca. 300.000 Dkr. til ovennævnte støtte og stipendier.

- Fondet for dansk-norsk samarbeid

Fondet bruker årlig ca 10 mill DKK (ekskl. administrasjon) til opphold og tilrettelegging av opphold for stipendiater og stipendiatgrupper på Lysebu og Schæffergården.

3. Hur många personer kan få stöd inom dessa stödordningar?

- Kulturförvaltningen i Stockholm stad / Nordiskt kultursamarbete Resestipendium ca 60 per år. Veckostipendium ca 10 per år. Vistelsestipendium ca 20 per säsong och år. OBS! För samtliga gäller att man ska vara mantalsskriven i huvudkommunen.

- Kulturfonden för Finland och Norge/finländsk fonddel Ca 50 personer och 7-10 mindre grupper/skolklasser.

- Kulturfonden för Finland och Danmark/finländsk fonddel $\mathrm{Ca} 40$ personer och 5 mindre grupper/skolklasser.

- Kulturfonden Island-Finland Ca 30 personer och 5 mindre grupper/skolklasser.

- Svensk-norska samarbetsfonden

Projektstöd beviljas både till enskilda och grupper. Antalet är därför svårt att ange. Vistelsestipendier ges också till enskilda och grupper. För år 2005 beviljades ca 580 vistelsedygn till Voksenåsen och 10 till Hässelby. Konstnärstipendier beviljas i form av antal veckor samt ett resebidrag. Ca 8 - 10 stipendier kan beviljas.

- Kulturfonden för Sverige och Finland/det finländska utskottet 
Fonden beviljade ca 250 veckor för år 2005 till ca 210 personer för en eller två veckors vistelse i Stockholm. År 2005 beviljades 32 veckor för vistelse på andra orter motsvarande 27.200 euro (ca 30 personer). Därtill våra allmänna bidrag (läs vänligen ovan).

- Fonden för Färöarna

1 ung person/stipendiat per gång i åldern 20-40 år.

- Kulturfonden för Sverige och Finland

Vistelsestipendier: År 2005 fick 146 personer ett stipendium från Sverige. Sammanlagt 441 dygn till Hanaholmen, 13 till övriga Finland. Projektstödet (83 stödmottagare, både grupper och enskilda) innebär ju också oftast en vistelse när det utbytes/samarbetsprojekt inom t ex musik, teater osv.

- Svensk-isländska samarbetsfonden

Antalet resestipendier kan variera från 11 - 16 beroende på ekono$\min$.

- Svensk-danska kulturfonden

Årligen 5 - 8.

- Dansk-islandsk forbundsfond

5 - 10 personer årligt under formål 1 og 2. [1. styrke den åndelige forbindelse mellem landene. 2. Fremme islandsk forskning og videnskab.]

- Dansk Færøsk Kulturfond

Det er meget skiftende, da antallet af dem der ansøger om støtte varierer fra år til år. Antallet af både personer, grupper eller projekter kan variere fra ca 20 til ca 40 .

- Fondet for dansk-norsk samarbeid

Totalt antall med opphold på Lysebu og Schæffergården i 2005 var 1600 personer og 5000 døgn.

4. För vilka ändamål beviljas rese- och vistelsestipendierna?

- Kulturförvaltningen i Stockholm stad / Nordiskt kultursamarbete Resestipenium för enskilda professionella kulturutövare med samarbetspartner i annan nordisk huvudstad. Veckostipendium för kommunalt anställd att få följa arbetet vid annan kommunal institution eller kulturförvaltning i annan nordisk huvudstad. Vistelsestipendium för arbete och/eller rekreation under vistelse i Stockholm.

- Kulturfonden för Finland och Norge

- Kulturfonden för Finland och Danmark 
- Kulturfonden Island-Finland

Både för att kunna inbjuda nordbor till Finland och för att stipendiaten själv åker till det andra nordiska landet. För träff med samarbetspartner, för bilaterala möten, för att knyta nya kontakter, för språkstudier och forskning, för konstnärligt arbete (konserter, teaterföreställningar, utställningar).

- Svensk-norska samarbetsfonden

Vistelsestipendier beviljas för $\mathrm{t}$ ex research- och intervjuresor, forskning, lärarmöten, utställningar, i viss mån utbildning, en rad samhällsfrågor, historiker, musiksamarbete, workshops, samarbete mellan skolor och högskolor, översättningsverksamhet.

- Kulturfonden för Sverige och Finland/det finländska utskottet Forskare, lärare, konstnärer, representanter för olika föreningar m.m. önskar vistas i Sverige för studier av t.ex. samhälleliga förhållanden eller besök hos samarbetspartners, arkivforskning etc. Också t.ex. översättare vill besöka Sverige med anknytning till sitt skönlitterära arbete.

\section{- Fonden för Färöarna}

För att underlätta unga färingars möjlighet att delta i möten, kurser och seminarier i Finland, speciellt sådana som anordnas av föreningen Tjaldur- vänskapsförening Finland-Färöarna. Meningen är även att ge stipendiaten möjlighet att bekanta sig med sitt eget specialområde i Finland. Vi har inbjudit en journalist, en teolig och politiker.

- Kulturfonden för Sverige och Finland

Mest varierande och inom alla konstarter, men även för samhällsfrågor och syftesnära forskning (språk, humaniora, historia). Stöd/vistelser ges för turnéer, utställningar, workshops, deltagande i sv-fi arrangemang, översättningar, reportageresor, lärarträffar, lägerskolor, samarbete inom musiken osv, researchresor, studieresor osv.

- Svensk-isländska samarbetsfonden

Stipendier beviljas endast för bilateralt samarbete, ej deltagande i nordiska arrangemang osv. kan beviljas för medverkan i konserter och musiksamarbete, utställningar, research, för fysiska nätverk, ateljévistelser, elevresor, filmresor, dans, körresor, samarbete inom språkområdet osv.

\section{- Svensk-danska kulturfonden}

Vetenskapliga studier, research, deltagande i forskarseminarier, doktorandstudier $\mathrm{mm}$. Ibland beviljas även lärlingsvistelser inom hantverksyrken då tillgången till motsvarande utbildningar/vistelser i Sverige har minskat kraftigt och traditionen är starkare i Danmark. 
- Dansk-islandsk forbundsfond

Især til formål 1 og 2. [1. styrke den åndelige forbindelse mellem landene. 2. Fremme islandsk forskning og videnskab.]

- Dansk Fcerøsk Kulturfond

Der gives støtte til formål inden for teater, film, musik og kunst, bogudgivelser, visse studierejser m.m.

- Fondet for dansk-norsk samarbeid

Stipend blir gitt til enkeltpersoner og grupper som har et faglig formål med oppholdet som er relevant for fondets formål: øke kunnskapen om nabolandet og bidra til samarbeidet mellom de to land.

\section{Nämn fasta samarbetspartner}

- Kulturförvaltningen i Stockholm stad / Nordiskt kultursamarbete Kulturnämnderna i Helsingfors, Köpenhamn, Oslo, Reykjavik, Mariehamn, Torshavn och Nuuk.

- Svensk-norska samarbetsfonden

Föreningen Norden i Sverige, Foreningen Norden i Norge, Voksenåsen i Oslo.

- Kulturfonden för Sverige och Finland/det finländska utskottet Wallin hotell i Stockholm, Kulturfondens för Sverige och Finland svenska sekretariat/Föreningen Norden.

- Fonden för Färöarna

Föreningen Norden på Färöarna och Pohjola-Norden i Finland

- Kulturfonden för Sverige och Finland

Varierar; mer eller mindre fasta samarbetspartners blir oftast aktuella i samband med fondens egna projekt: $t$ ex inför år 2009 är Riksbankens jubileumsfond finansiär och samarbetspartner kring ett forskningsprojekt. Hanaholmens kulturcentrum är givetvis fast partner.

- Svensk-isländska samarbetsfonden

Främst fondens egna projekt: Isländsk-svensk ordbok: Göteborgs universitet och Háskola Órðabók, Knut och Alice Wallenbergs stiftelse. Kulturministeriet på Island (ger årligen ekonomiskt stöd för utlysnings och resekostnader). Kulturdepartementet i Sverige (kan ge projektstöd och ibland även stöd för utlysning och möteskostnader). Ambassaderna i Stockholm och Reykjavik har bistått fonden och adjungeras till fondens möten.

- Svensk-danska kulturfonden 
Evers \& COs fond, Danmarks ambassad i Stockholm (har en adjungerad representant i styrelsen).

- Dansk-islandsk forbundsfond

Fondet har ingen faste samarbejdspartnere.

- Dansk Fœrøsk Kulturfond

Fondet har ikke nogen faste samarbejdspartnere.

- Fondet for dansk-norsk samarbeid

Seminarier og lærerhøgskoler, universitetene, Kunst i skolen, Norske grafikere, Voksenåsen, Hanaholmen.

6. Idéer och tankar om hur man i framtiden kan koordinera samarbetet med det nya nordiska mobilitets- och residensprogrammet?

- Kulturfonden för Finland och Norge

- Kulturfonden för Finland och Danmark

- Kulturfonden Island-Finland En tydlig, centraliserad informationskanal för de olika stödprogrammen.

- Kulturfonden för Sverige och Finland/det finländska utskottet Att informera (och uppdatera informationen) om alla olika nordiska mobilitets- och residensprogrammen under en webbadress. Kulturfonden för Sverige och Finland/finländska utskottet låter utvärdera sina vistelsestipendier under år 2006.

- Svensk-norska samarbetsfonden

- Kulturfonden för Sverige och Finland

- Svensk-danska kulturfonden

- Samarbetsfonden Sverige-Island

Detta är en svår och olöst, hoppeligen inte olöslig, fråga. Det gäller för övrigt inte bara de bilaterala fonderna - det gäller också för andra. I Sverige vet jag att Stockholms stad har residensstipendier, liksom Nordiska akvarellmuseet och Östersjöns litteraturcentrum i Visby. Säkert också andra.

De olika bilaterala fonderna har olika förutsättningar. Vad gäller de fonder Sverige är inblandade i har Kulturfonden för Sverige och Finland stora resurser för vistelsestipendier medan ex. Svensk-danska kulturfonden har obefintliga. Nu får Svensk-danska ökade resurser. Från svensk synpunkt vore det angeläget att särskilt främja residensstipendier i vår relation till/från Västnorden. En annan fråga är vilka krav spm ska ställas på residensen. 
Kan NMR bidra med att inventera vilka residens som är särskilt lämpade för utbyte över gränserna - vi vill väl inte att residenten ska vara en solitär utan möjlighet att komma i kontakt med kolleger i grannlandet. Kanske kan denna enkät utgöra grunden för en broschyr i vilken residensstödordningarna presenteras så fullständigt som möjligt. En sådan behövs och den måste vara grunden för framtida koordinering.

En huvudfråga bör vara vilka som omfattas av NMR:s residensprogram. Ska det bara vara professionella aktörer inom de olika konstområdena? Vilka konstområden omfattas? Kan residensordningen också inkludera anställda och förtroendevalda i frivilligorganisationer av betydelse för kulturutbytet i Norden? Om inte, vad är anledningen till att utesluta dem?

En principfråga är också vem som ska ha stöd: är det arrangören, det vill säga den som ansvarar för residenset, eller är det de individer som som vill gästa residensen? Kunde en arbetsfördelning vara att NMR ger stöd till residensen, att individerna som vill dra nytta av stipendierna söker stöd hos de residens som NMR valt att ge stöd till medan de bilaterala fonderna kunde ge resestöd till individer som fătt del av residensens stipendier. En sådan ordning skulle fungera i "fenno-skandinavia". NMR skulle sedan kunna komplattera med en särskild ordning för Island, Färöarna och Grönland som även inkluderar resebidrag.

\section{- Fonden för Färöarna}

Föreningen Tjaldurs styrelse som i samarbete med fondens sekreterare som även är verksamhetsledare för Tajldur utarbetar ett specialprogram för stipendiaten, bokar Hotel och resor. Tjaldur avsetter dessutom en summa pengar även för stipendiatens besök, bjuder på hembesök, middagar mm. Finns här någon möjlighet att koordinera $t$ ex anvånda något speciellt Hotell i Helsingfors som även användas tex av Nifin för att få billigare Hotellövernattningar med Norden rabatt. Flygen är trots allt dyrast och vår egen administration.

- Stiftelsen Svensk-danska kulturfonden

Svensk-danska fondens resurser har förstärkt avservärt genom ett kapitaltillskott från Sveriges regering. Bidrags/verksamhetsformerna fastställs under detta år och verksamheten ska igångsättas från 2007.

- Dansk-islandsk forbundsfond

Fondet ser gerne et samarbejde med Nordisk kulturfond omkring uddeling af bilaterale dansk-islandske stipendier inden for det nye program. Det måtte da især dreje sig om formål der ligger inden for fondets virkeområde. Fondets bestyrelse sidder her inde med stor erfaring, der kunne komme sagen til gode. Man kunne forestille sig, at fondets bestyrelse fik overdraget nogle midler til uddeling, eller at fondets bestyrelse var repræsenteret $i$ en uddelingsprocedure under Kulturfonden. 
- Dansk Færøsk Kulturfond

Da vores fond ikke har de helt store økonomiske resurser er det begrænset, hvad vi kan bidrage med økonomisk i det kommende støtteprogram hos Nordisk Kulturfond. Dog ville det for vores fond og de andre bilaterale fondene være godt, om de respektive fonde i god tid fra Nordisk Kulturfond fik informationer om kommende projekter, der af interesse, muligvis ville blive støttet af de bilaterale fonde. 


\section{Bilaga 5. Lokaler som disponeras av Nordiska institutet för samtidskonst - NIFCA}

Förvaltningsnämnden för Sveaborg

\begin{tabular}{|c|c|c|}
\hline Byggnad & $\mathrm{nr}$ & Namn \\
\hline \multirow[t]{2}{*}{ B } & 28 & Garnisonskasernen "Kolchosen" \\
\hline & & $\begin{array}{l}\text { Lokaler för kontor, bibliotek, verkstad och utställning (Galleri Augusta) } \\
\text { Rumsareal totalt } 1627 \mathrm{~m} 2\end{array}$ \\
\hline \multirow[t]{2}{*}{ B } & 37 & Majorens hus \\
\hline & & $\begin{array}{l}\text { Representationslägenhet (delvis möblerad) och två mindre lägenheter } \\
\text { Lägenhet A } 249 \mathrm{~m} 2\left(^{*} 1\right. \\
\text { Lägenhet B } 5124 \mathrm{~m} 2\left({ }^{*} 1,2\right. \\
\text { Lägenhet B } 674 \mathrm{~m} 2\left(^{*} 1\right. \\
\text { Areal totalt } 247 \mathrm{~m} 2 \\
\text { Obs *1: rummen } 208 \text { och } 213 \text { kan förenas med grannlägenheterna. } \\
\text { Obs *2: } 74 \mathrm{~m} 2 \text { av representationslägenheterna ingår i hyran. }\end{array}$ \\
\hline \multirow[t]{2}{*}{ B } & $44-45$ & Ateljéhuset Bastionen Palmstierna \\
\hline & & $\begin{array}{l}\text { Ateljélägenheter (5 st.) och gästrum (4 st.) } \\
\text { Lägenhet E } 14 \text { Ateljé Augustin } 78,5 \text { m2 } \\
\text { Lägenhet F } 15 \text { Ateljé Carl August } 78,5 \text { m2 } \\
\text { Lägenhet F } 16 \text { Ateljé Elias } 80 \text { m2 } \\
\text { Lägenhet G } 17 \text { Ateljé Emanuel } 97 \mathrm{~m} 2 \\
\text { Lägenhet G } 18 \text { Gästrum Sergei } 31,5 \mathrm{~m} 2 \\
\text { Lägenhet G } 19 \text { Gästrum Heikki } 33,5 \mathrm{~m} 2 \\
\text { Lägenhet H } 20 \text { Gästrum Signe } 31.5 \mathrm{~m} 2 \\
\text { Lägenhet H } 21 \text { Gästrum Nina } 33.5 \text { m2 } \\
\text { Lägenhet L } 25 \text { Ateljé Johan Tobias } 119,5 \text { m2 } \\
\text { Areal totalt } 583,5 \text { m2 }\end{array}$ \\
\hline \multirow[t]{2}{*}{ C } & 63 & Skyddsrum \\
\hline & & $\begin{array}{l}\text { Uppvärmd lagerlokal (möbler, förpackningsmaterial etc) } \\
\text { Areal ca } 100 \text { m2 }\end{array}$ \\
\hline
\end{tabular}




\section{Referenser}

Annual report 2004. Office for Contemporary Art. Norway.

Artist on the Move. Report. SICA Conference 7. - 8. oktober 2004. www.sica.nl/pdf/Reportartistsonthem ove2004.pdf (jan. -06)

Audéoud Oliver. Study on the mobility and free movement of people and products in the cultural sector. Study No DG EAC/08/00. Partnership CEJEC - Université PARIS X-EAEA 2002.

http://www.eu.int/comm/culture/eac/s ources info/pdf-

word/mobility_en.pdf (jan. -06)

Internationella kulturutredningen 2003.

Betänkande av Internationella kulturutredningen. SOU 2003: 121, Stockholm.

Jönsson Love (ed.). 2005. Craft in dialogue. Six views on a practice in change. IASPIS. Stockholm.

Karttunen Sari. 2005. Taidetoimikuntalaitoksen kansainväliset avustukset taiteilijoiden liikkuvuuden ja vierastalojen tuki 2000-2004. Työpapereita Working papers no 43. Arts Council of Finland. Research Unit. Helsinki.

Konstnärerna och trygghetssystemen. Betänkande av Utredningen om konstnärerna och trygghetssystemen. SOU 2003:21. Stockholm.

Möntman Nina, Sheikh Simon. 2004. NIFCA: An Art Institution as a Copractising Institution? Concepts and Ways of Implementation. Report. NIFCA, Helsinki.
Saha Hannu (ed.). 2005. ARSIS 3/05: Artist-in-Residence activities. Arts Council of Finland. Helsinki.

Scenerum.org. A virtual work space for artists throughout the Nordic countries. 2005. Nordic Centre for the Performing Arts. DVD.

Staines Judith. Artists'International Mobility Programs. D'Art question 17.

http://www.ifacca.org/files/040901mo bilityq.pdf (jan. -06)

Strukturgruppens rapport till Nordiska ministerrådet.

http://www.norden.org/kultur/sk/dok2 1_arbejdsgruppe_rapport.pdf (jan. 06)

Suomi Riikka (ed.). 2004. The Artists Study. The Survey on Pépiniéres Artist-in-Residence Programmes 19902004. The Observatory of new expressions / map-mobility in art process. Report. Pépiniéres.

Suomi Riikka. 2005. Kansainvälinen taiteilijaresidenssitoiminta Suomessa 1995-2005. Työpapereita - Working papers n:o 44. Arts Council of Finland. Research Unit. Helsinki.

Verksamhetsberättelse 2004. Östersjöns Författar- och Översättarcentrum. Visby.

Årsrapport 2004. Sleipnir resestipendier. NIFCA. Finland.

Årsredovisning år 2004. Konstnärsnämnden. Sverige. 


\section{Kort om utredaren}

Utredningen är utförd av Riitta Heinämaa, som för närvarande arbetar som planeringschef på Teaterhögskolan i Helsingfors. Till hennes uppgifter hör bl.a. resultatstyrning och flera strategiska utvecklingsprojekt. Under åren 1998-2002 arbetade Riitta Heinämaa som direktör på Nordens Hus i Reykjavik. Före det fungerade hon som chef för undervisningsteatern vid Teaterhögskolan. Heinämaa har också arbetat som föredragande sekreterare för statens kommission för danskonst. Heinämaa har en bred erfarenhet av kulturbranschen och har tidigare arbetat som producent för teater och dans och som utbildare för producener och kulturchefer. 